فاعلية برنامج تذريبى مقترح لتنمية بعض خصائص التفكير الإيجابى

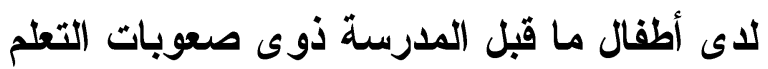

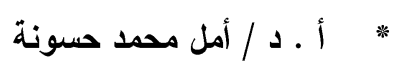

"* * أ ـ أ د / محمد إبراهيم عبد الحميد

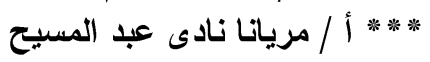

\title{
هذص البمث
}

عنوان البـث : فاعلية برنامج تدريبي مقترح لتنمية بعض خصائص التفكيـر الإيجابي لدى أطفال ما قبل المدرسة ذوى صعوبات التعلم . هـدف البحثث : يهدف البحث الحالى إلى محاولة التأكد من فعاليـــة البرنــامج التثريبي المقتر ح لتتمية بعض خصائص التفكير الإيجابي لدى أطفال ما قبـلـل المدرسة ذوى صعوبات التعلم . عينة البحث : تكونت عينة البحث من ( • ب ) طفلاً وطفلة من أطفال الروضة ذوى صعوبات التعلم من أطفال المستوى الثانى و التى تز اوحت أعمار هم مـنـن

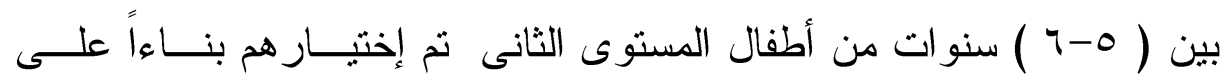
الدر اسة الإستطلاعية التى قامت بهم الباحثة حيث تم تقسيمهر إلى ( • () أطفال من المجموعة التجريبية و( • ( ) أطفال من المجموعة الضابطة . أدوات البحثث : إختبار رسم الرجل جودانــف هاريس،و إســتمارة المســتوى الإجتماعى والأقتصادى ، بطارية صعوبات التعلم النمائية ، مقياس خصائص مل التفكير الإيجابى لطفل الروضة .

* أستاذ علم نفس الطقل " الصحة النفسية " وعميد كليـة ريـاض الأطفال ورئسيس قسم

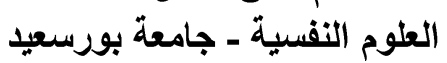
** أستاذ مناهج الطقل بقسم العلوم التريوية ووكيل كلية رياض الأطفال لثئون الاراسـات

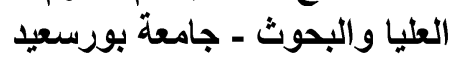
*** معيدة بقسم العلوم النفسية ــ كلية رياض بور الأطفال - جامعة بورسعيد 


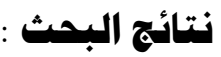

() توجد فروق ذات دلالة إحصائية بين منوسطات رثب درجات أطفال كـلـل من أطفال المجموعة التجريبية ودرجات المجموعة الضابطة على مقياس خصائص التفكير الإيجابى لصالح التطبيق البعدى . r) توجد فروق ذات دلالة إحصائية بين متوســط رتـب درجــات أطفــال المجمو عة التجريبية فى القياس القبلى و البعدى على مقيــاس خصــائص التفكير الإيجابى وأبعادة الفرعية لصالح التطبيق البعدى" r) لاتوجد فروق ذات دلالة إحصائية بين متوسطات رتب درجــات أطفــال

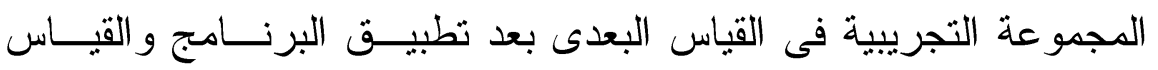
التبتعى بعد مرور شهر من إنقضاء البرنامج علــى مقيــاس خصـــائص

$$
\text { التفكير الإيجابى و أبعادة الفرعية . }
$$

الكلمات الانتتاحية : التفكير الإيجابى ـ صعوبات التعلم .

\section{Abstract :}

Research Titel: Effectiveness of Training Program on Based the Development of Some Positive Thinking among the Characteristics of Pre-school Children with Learning disabilities

Research Goals: The current research is aimed at trying to make sure the impact of the training program based on the development of some of characteristics of positive thinking.

Human Limitations: Research sample consisted of (20) children (from both genders) from kindergarten with learning 
disabilities, which their ages between (5-6) years old, they're chosen upon conducted survey by researcher who divided them on two groups as (10) children for both of control and (10) children for experimental groups.

Research Tools: Test draw a man to Good Enough Hares, Economic and social levels Form, Battery developmental learning disabilities, A measure of positive thinking kindergartners properties

\section{Result of research:.}

1) There are significant differences between the mean scores of the experimental group \& control group on the scale of characteristics of positive thinking in favor of post-scale.

2) There is a statistically significant difference between the mean scores in both of the children of the experimental group and children of the control group on both of pre \& post measurement on manifestations of positive thinking scale and its sub-dimensions for the post-measurement.

3) There is not a statistically significant difference between the mean scores in the children of the experimental group in both of iterative\& post-measurement after applying the program for month on manifestations of positive thinking scale and its sub-dimensions.

Research Words: Positive Thinking,Learning Disabilities 
إن سلوك الأطفال بين الرابعة و السادسة محصلة لمفاهيمهم عن ذواتهـم

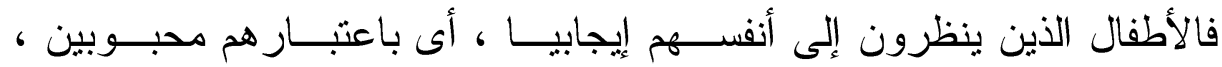

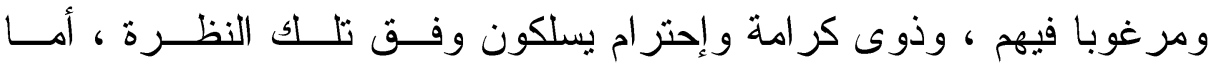

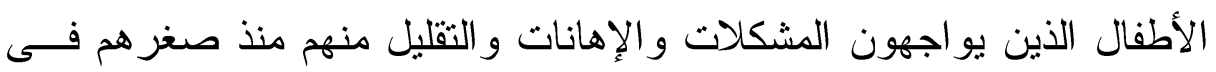
البيوت و الحضانات و الروضات ، فقد يكبرون لبــدخلو الســـون ومر اكـز

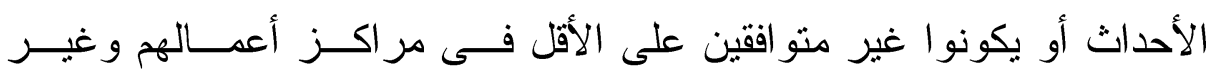
محبوبين ، لأن هؤلاء الناس ينظرون لأنفسهم بصورة سلبية ، باعتبار هم كما يشعرون بأنهم أفراد غير مرغوب فيهم وغير مقبولين ، لأن الطفل يتخيل أن من يحبه ير اه جميلا لطبفا جذابا ، فيشعر بجمال كل ما يحيط به بالســعادة ،

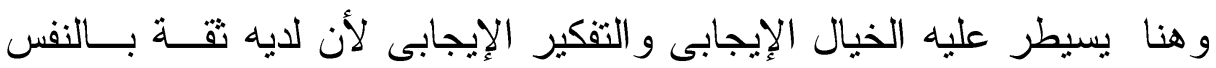

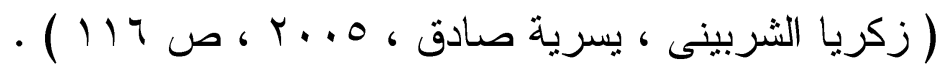
ولذلك يشير العديد من المربين و علماء النفس إلى اخــتلاف مســتويات الأطفال فى مرحلة الروضة من حيث استعدادهم ، وقدر اتهم ، و إمكانــاتهم ،

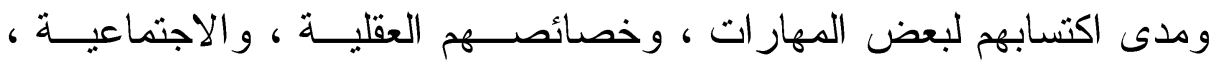
و الانفعالية ، و الحركية ، و السلوكية ويرجع ذلك إلى وجود فروق فردية بـين

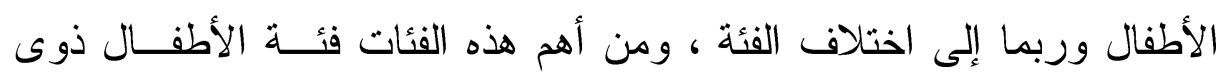
صعوبات التعلم التى أصبحت أكثر الفئات إنتشار اً فى مجال التربية الخاصــة التهـ و التى لاقت اهتماماً واسع المجال ، وذلك لزيادة عددالأطفال الذين يصنفون فى نطاق هذه الفئة . وتكمن خطورة مشكلة الأطفال ذوى صعوبات التعلم فى كونها صـــوبة

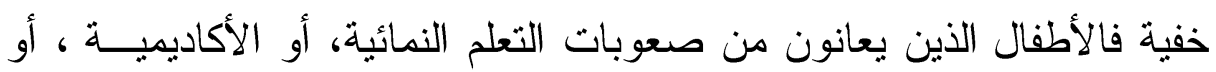

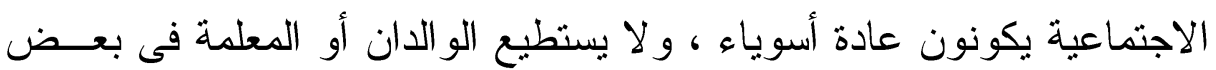


الأحيان اكتشاف هذه الصعوبات لتقديم بعض الأساليب العلاجيــة وخــدمات التربية الخاصة لهم ، مما يجعلهم يعانون من صعوبات التعلم وبعض المظاهر الاجتماعية و الانفعالية و السلوكية التى تتؤدى إلى التفكير السلبى مثل عدم القدرة على حل مشكلاتهم و اتخاذ القرارت ، تدنى مستوى الذات و عدم القدرة علــى الـى الانجاز وضعف الثقة بالنفس ، و الاتكالية وعدم تحمل المسئولية .

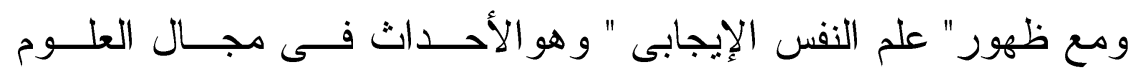
النفسية ، وهومجال يتطور بسرعة ويتركزطموحــة فـى تحقيـق البحــوث التجريبية الصلبة فى مناطق مثل التذفق ، و السعادة ، و الرفاهية ، ونقاط القوة الشخصية ، و الحكمة ، و الإبداع ، و الصحة النفسية و الخصـــائص الإيجابيــة

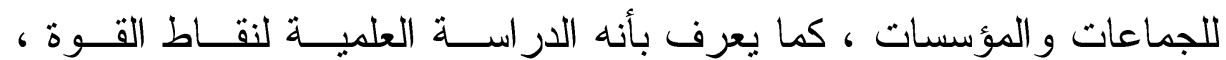
و الفضائل التى تمكن الأفر اد و المجتمعات من الأزدهار .

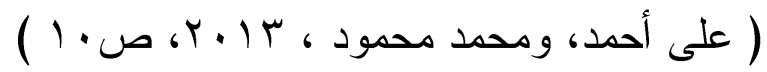

وقد أثثتت در اسة (Bob,A, et al.,2012) أن إضــطر اب صـــوبات

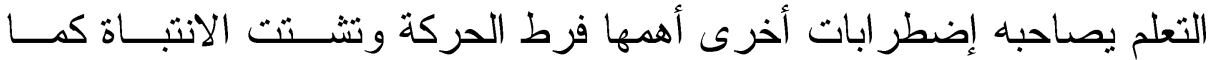
يصاحبه مظاهر سلوكية سلبية كضعف الانجــاز الاكــاديمى وضـــف أداء الأنشطة الإجتماعية و التو اصل و عدم الثقة بالنفس ، و عدم التمكن مــن حـلـ الته

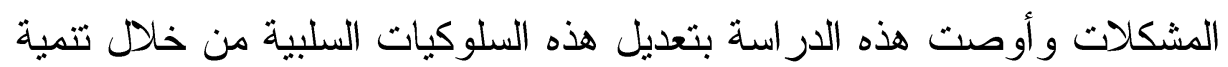
مهار ات التفكير لهؤلاء الأطفال و التى تساعدهم على التخلص من هذه السمات السلبية وتحسن من قدر اتهم على التعلم و التحصيل الاكاديمى . و أيضا (Shepherd,R.,2014.p.83) أن هناك بعـض الأحتياجـات

الأساسية للأطفال الذين يعانون من صعوبات التعلم و أهمها الممارسة المبنيـة فئة على المعرفة و المهار ات و الفهر ، فإن المساعدة المبكرة و الفعالة لهؤلاء الطلبة

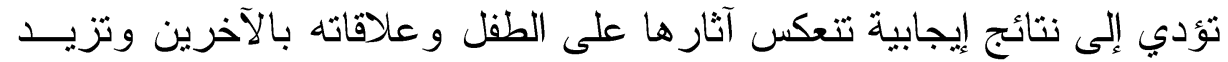

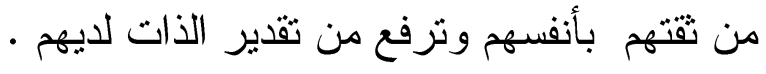


لذلك فقد أستقر مفهوم التفكير الإيجابى من خلال عدة مفاهيم متنوعة ، من أهمهما التفكير البنائى Constructive Thinking الذى قدمته النظريـــة البنائية وهو يركز على أكتساب بعض المهار ات النفسية التى تســاعد علـىى

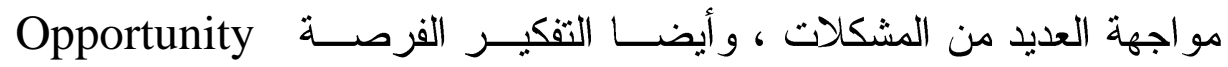
Thinking و الذى قدمه سوليفان و هو يركز على زيادة إنتباه الفرد وتقكيــرة من أجل تحقيق النجاح فى أى مشكلة والجو انب التى تؤدى إلى تحدى المشكلة

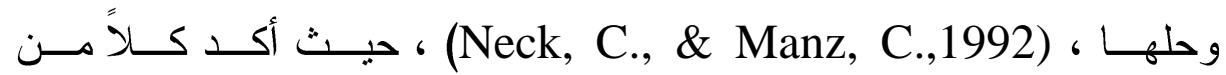
(Juile,K.,\&Edward.C.,2002.pp.993-1001) وتوجيهات علم النفس الإيجابى على الأفراد المستخدم من أجل زيــادة الأداء الوظيفى الإنسانى ، فى الوقت الذى يزداد فيه إنتشار علم النفس الإيجابى على الى كلا من الصعيدين داخل علم النفس ، و على صعيد الثقافة بشكل عــام ، كمـــا يشمل علم النفس الإيجابى على التفكير الإيجابى و السلبى و الذى يتمثـلـل فـى أساليب التفكير التى قد تختلف فى القيم وفو ائد من حيث التفاؤل و التشاؤم الذى الإي ولئي يختلف من فرد لأخر ، ومن موقف لأخر ، ومن ثقافة لأخر . ونتيجة لذلك ظهر التفكير الإيجابى وهونوع من أنواع التفكير التى تعتمد

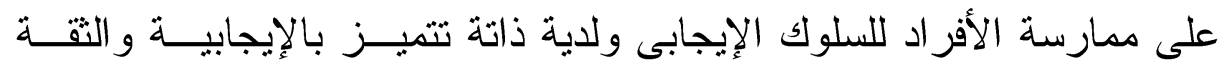
بالنفس أيضا وشعور بالسعادة و التفاؤل وقدره لحل المشكلات المختلفــة فــى دئ

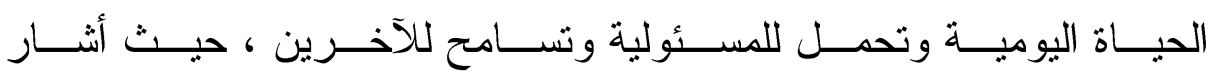
دراسة (McGuinness, C.,2013 ) إلى أن الطفل بطبيعته مفكر ، ويجــب تدريب الأطفال على مهار ات التفكير الإيجابى منــذ صـــز هم فــى مرحلـــة

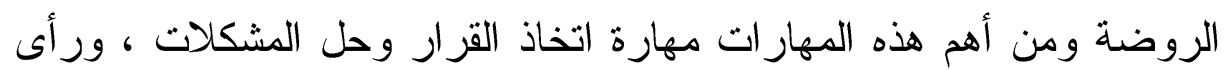

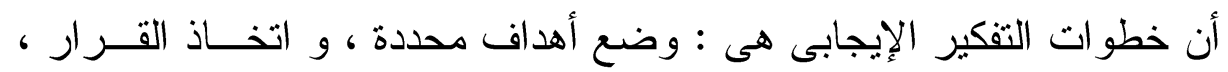
ومهار ات التقة بالنفس ، الإستقلالية ، إحتر ام الذات ، الشعور بالتفاؤل . 
كما اهتمت در اسة (Patnaik,G.,2013.p.121) التى بعنـــوان أثــر التفاؤل و المشاعر الإيجابية على الصحة النفسية بتوضــيح ان علــم الــفس الإيجابى يساعد الطفل على التفاؤل وتفسير المواقف و الأحداث بشكل أفضـلـل

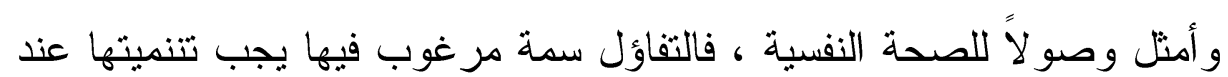
الأطفال الصغار ، كما أن التفكير الإيجابى يساعد على التقة بالنفس من أجـلـ هله تحقيق الرفاهيه النفسية النى هى ضرورة للصحة النفسية الجيدة .

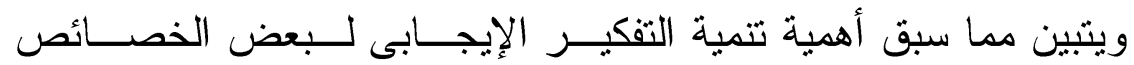
الإيجابية مثل حل المشكلات ، و الثقة بالنفس ، وتحمل المسئولية و الذى ألقـــ

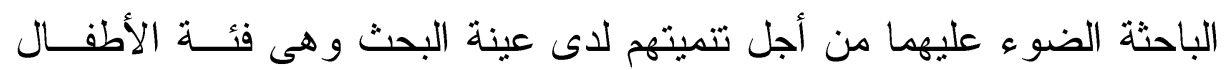

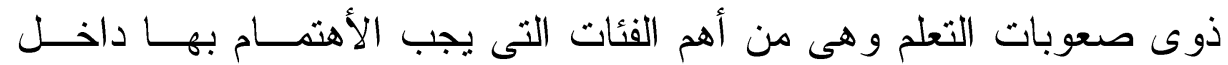
الروضات وتقديم الأنشطة المناسبة لها و البرامج التربوية و العلاجية المناســبة

يتبين مما سبق أهمية تتمية بعض خصائص التفكير الإيجابى لدى هؤلاء الأطفال فى مرحلة الروضة فى الوقت الذى تتــدر فيــهـ البـــر امج التدريبيـة الموجهه لتتمية بعض الخصائص لدى هذه الفئة من الأطفال ، هذا بالأضـــافة إلى ما لاحظته الباحثة خلال العمل بالتدريب الميدانى والزيـــار ات الميدانيــة

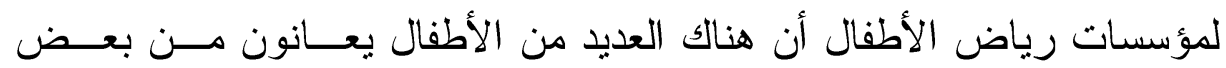
صعوبات التعلم التى تجعلهم يفكرون بشكل سلبى فليس لديهم القدرة على حل مشكلاتهم ويتميزون بعدم الثفة بالنفس و الأعتمادية ممايترتب عليه تكوين أفكار تتميز بالسلبية وبالفشل و الخمول و عدم التفاؤل وقله إحتر ام للذات لديهح . ومن هنا جاءت فكرة البحث الحالى التى تستهدف تصميم برنامج تدريبى قائم على تنمية بعض خصائص التفكير الإيجابى لدى أطفال ما قبل المدرســة

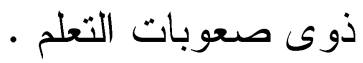


نمت مشكلة الدراسة من خلال الإطلاع على الأدبيات و الأطر النظريـــة و إجر اء إستطلاع ر آى لأولياء الأمور و المعلمات بالروضة عن أهم المظـــاهر السلوكية التى يتم ملاحظتها على الأطفال ذوى صعوبات التعلم من عدم القدرة على حل مشكلاتهم ، وضعف التقة بالنفس ، و الاتكالية وهذه تعتبر مؤشــر ات

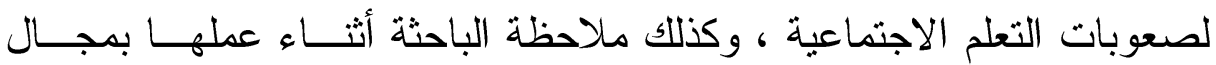
التدريب الميدانى عن وجود بعض الأطفال يعانون من صعوبات تعلم نمائية ، حيث أن عدم الإهتمام بهذه الصعوبات النمائية يؤدى إلى صعوبات أكاديميـة فى المر احل الأخرى اللاحقة من مرحلة الروضة وظهور بعض الخصــائص و السلوكيات لديهم التى تؤثز عليهز فى العديد من المجالات والتى تؤثر بدورها

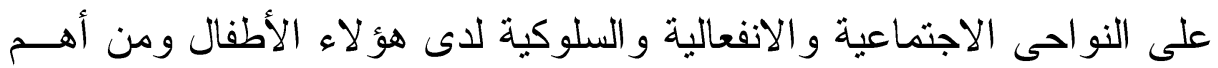
هذه المظاهر الاتكالية وعدم تحمل المسئولية ، وضعف الثقة بالنفس مما يؤدى إلى نقص الدافعية لديهم ، و عدم القدرة على حل المشكلات و اتخاذ القـــرار ات

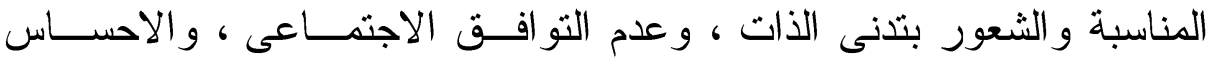
بالفشل ، والاكتئاب ، ونقص الشعور بالأمن و الانسحاب الإجتماعى ( خولــة

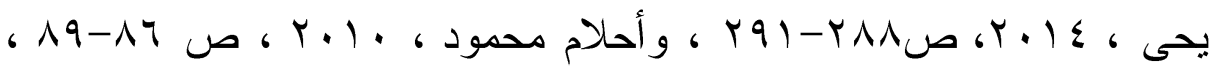

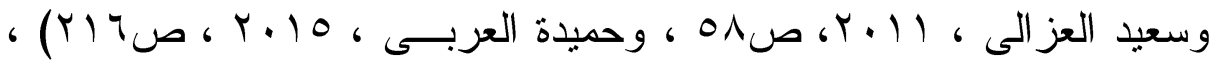
حيث أشارت در اسة ( Livingston, K,2000) أن الأطفال ذوى صــعوبات

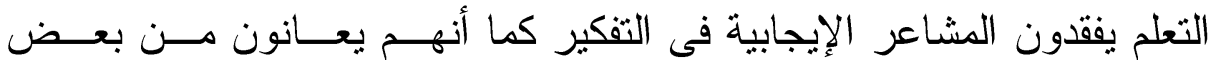
الضغوط فى حياتهم، وأسفرت نتائج الدر اسةعن وجود علاقة قوية وبارزة بين نسبة الذكاء و العو امل الوقائية ، و أن الأطفال ذوى صعوبات التعلم لديهم نسبة ذكاء مثل الأطفال العاديين تمكنه من القدرة علـى : تحمـلـل المســؤية ، و السيطرة الداخلية ، و القدرة على طلب المساعدة بشـــل لاعــق ، و التفكيـر 
الإيجابى ، و التوقعات الإيجابية ، وتتمية مهار ات اللازمة لحــل المشــكلات ، وتعليم الطفل مبادىء المو اطنه ، و المشاركة الفعالة . وبناء على ما سبق فقد إهنمت الباحثة بتنمية بعض مظـــاهر التفكيــر الإيجابى ، وذلك لقلة الار اسات التى اهتمت بتوجية هذا النوع من التفكير لهذة الفئة فى مرحلة رياض الأطفال ، فبعض الدراسات اهتمت بتنميــة التفكيـر

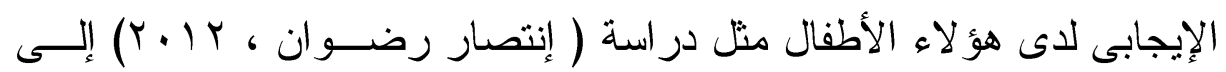

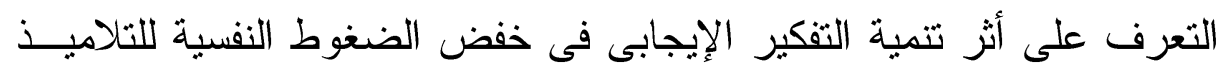

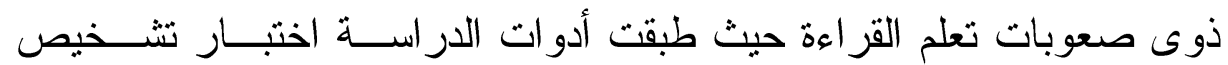
صعوبات القراءة ، اختبار الذكاء المصور ، استبيان الضغوط النفسية ، حيث كثفت النتائج عن عدم وجود فروق دالة إحصائباً فى التفكير الإيجـابى بـين متوسطات رتب المجموعة التجريبية فى القياسين البعدى و التتبعى .

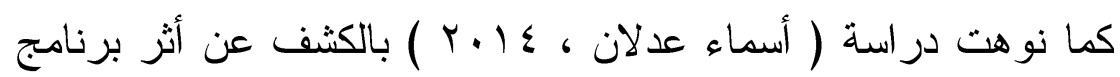
تدريبى قائم على مهار ات التفكير الإيجابى فى تتمية بعض سمات الشخصية ، وحل المشكلات الحياتية لدى تلاميذ الإعدادية ذوى صعوبات التعلم ، وتتبع أثز البرنامج التدريبى لتنمية بعض سمات الثخصية ( الثقة بالنفس ، التفاؤل ، المرونة ، حل المشكلات الحياتية ) لدى أفراد العينة .

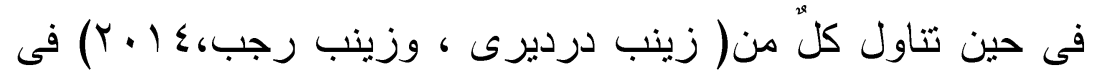

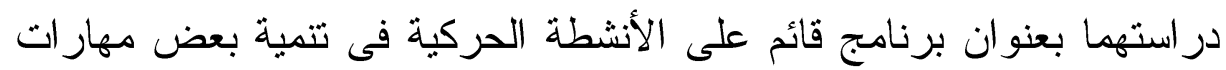
التفكير الإيجابى لدى أطفال الروضة بطيئي التعلم لتعليمهم مهارات التفكير الإيجابى بما يسمح بتحسن أداء مهارات التعاون والتواصل والثقة بالنفس بهابـ وتحمل المسئولية ، وأسفرت النتائج عن وجود تأثير جوهرى للبرنامج بعد تطبيقة، واستمرارية تأثيرة فى تتمية مهار ات التفكير الإيجابى بما بسمح بتحسن أداء مهارات التعاون ، و التو اصل ، و التقة بالنفس وتحمل المسئولية ، وقد أوصت الدراسة بالتأكيد على نشر ثقافة التفكير الإيجابى لدى معلمات 


\section{فاعلية برناهج تدريبى لتنمية بعض خصائص التفكير الإيجابى}

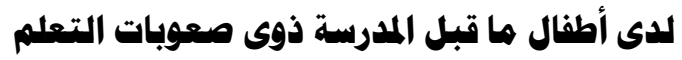

رياض الأطفال عامة وذوى الاحتياجات خاصة كالتوحد وصعوبات التعلم و المعاقين سمعياً وبصرياً .

ولذلك فترى الباحثة أن هؤلاء الأطفال بحاجه ماسة إلى تتمية بعـض أن خصائص التفكير الإيجابى لديهخ ، من أجل التغلب على الصعوبات النمائية التى يعانون منها وتتمية قدر اتهم على النجاح فى مختلف أمور حياتهم . لذلك يعد التفكير الإيجابى نوع من أنواع التفكير الذى تشير إلبه العديد

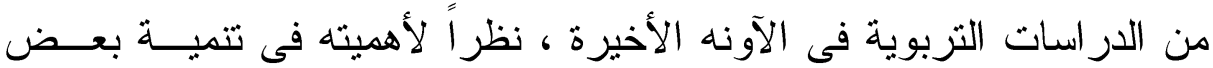
مهار ات التفكير ، وما يتميز به من الخصائص التى يمكن تتميتها لدى شخصية الأطفال و الكبارفى مختلف المراحل العمرية ، للتعامل مع تحديات المستقبل ، و التى تتمثل فى إحتر ام الفرد لذاته وزيادة قدرته على التأقلم لحل مشــكلاته ، و التو اصل الإيجابى مع الآخرين و الأعتماد على النفس و الثقة بها ـ حيث هدفت دراسة ( Goldberg,C.,2005 ) إلى تتمية مهار ات حـل المشكلات لدى عينة من أطفال ذوى صعوبات الـتعلم مــن خــلال برنــامج كمبيوتزى مقترح ، وتتمية الثقة بالنفس من خلال التغذية الر اجعة ، وتــدريب الطفل على مهار ات حل المشكلات التى يبدأ من إثارة حب الاستطلاع وتفسير الحلول و الثقة بالنفس ومهارة حل المشكلات لدى هؤلاء الاطفال .

\section{تتحدد مشكلة البحث الحالى فى الإجابة عن التساؤلات الأتية :}

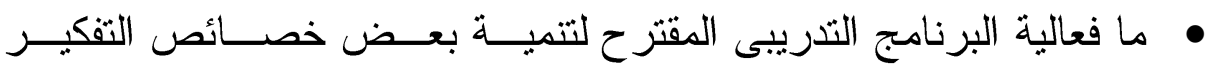
الإيجابى لدى الأطفال ذوى صعوبات التعلم ؟

ويتفرع هن هذا السؤال الرئيسى هجموعة هن التساؤلات الفرعية الأتية :

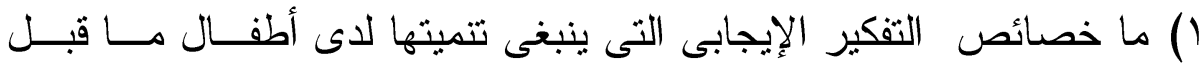
المدرسة ذوى صعوبات التعلم ؟ 
r) هل توجد فروق بين القياسين القبلي و البعدي علــى مقيــاس خصـــائص

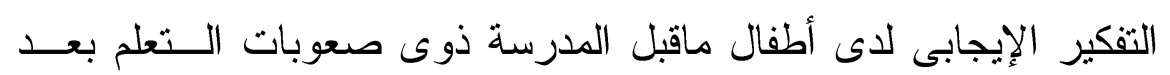

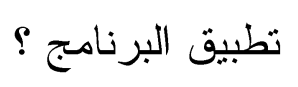

r) هل نوجد فروق بين القياسين البعدي و التتبعى على مقبـــ خصـــائص

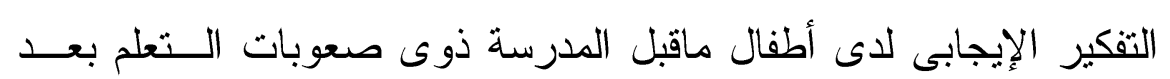

$$
\begin{aligned}
\text { أهداف البحث : شهر من تطبيق البرنامج ؟ } &
\end{aligned}
$$

يهدف البحث الحالى إلى محاولة التأكد من فعالية البرنامج التدريبي القائم

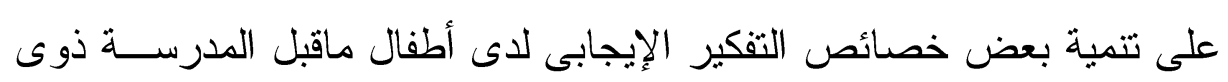
صعوبات التعلم ، وتتلخص الأهداف فيما يلي :

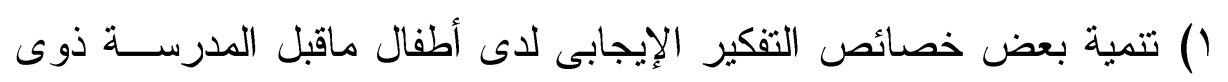

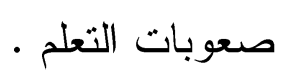

r) التعرف على خصائص التفكير الإيجابى التى يمكن تتميتها لــدى أطفــال ماقبل المدرسة ذوى صعوبات التعلم .

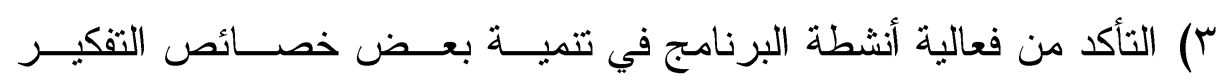
الإيجابى لدى أطفال ماقبل المدرسة ذوى صعوبات التعلم

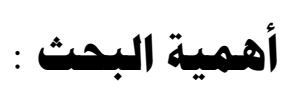

ترجع أهمية هذا البحث في الكشف عن فعالية البرنامج التـريبي القـائم على تتمية خصائص التفكير الإيجابى لــدى أطفــال ماقبـلـل المدرســـة ذوى صعوبات التعلم ، وتتطوي أهمية هذا البحث من الناحية النظرية و التطبيقيـة على يلى : 


\section{فاعلية برناهمج تدريبى لتنسية بعض خصائص التفكير الإيجابى}

لدى أطفال ها قبل المدربة ذوى صعوبات التعلم

\section{أولاً: الأهميمية النظرية :}

( ) الكثف عن أهم خصائص التفكير الإيجابى التى يمكن تتميتها لدى الأطفال بالروضات

r) أهمية در اسة خصائص الأطفال ذوى صعوبات الــتعلم للتغلــبـ عليهــا و القضاء على الصعوبات التى تو اجهه هؤلاء الأطفال . r) تقتح المجال لدر اسات أخرى تهتم بخصائص الأطفال ذوى صعوبات التعلم النمائية و الأكاديمية و الإجتماعية . ع) لفت أنظار معلمات رياض الأطفال و العاملين بالمجال بأهميــة الأهتمــام بالتقكير الإيجابى وتتمية خصائصة ومهار اته لدى الأطفال فـى مرحلـــة الروضة .

\section{ثانيًاً: الأهمهية التطبيسقية:}

() تسهم هذه الدر اسة في تتمية بعض خصائص التفكير الإيجابى لدى الأطفال ذوى صعوبات التعلم • بات r) قد يستفيد من الدر اسة كلاً من الآباء و المعلمات و الأخصــائيين النفسـبين و الإجتماعيين و أخصائيي الأطفال ذوى صعوبات التعلم في تدريب أطفالهح على بعض السلوكيات وتتمية بعض الخصائص لديهم من خــلال تطبيــق بر امج علاجية و إرشادية وتربوية .

هدود|لبمث :

الحسود الكانيسة : تم اختيار الأطفال عينة البحث من أطفال روضـــة مدرسـة عمروبن الخطاب التجريبية بمحافظة بورسعيد.

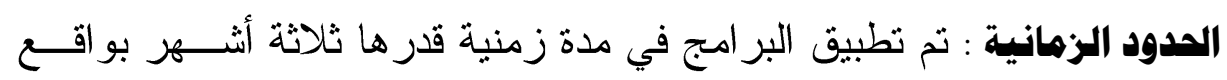
ثلاث أنشطة أسبو عياً وتستغرق مدة النشاط خمس و أربعين دقيقة . 


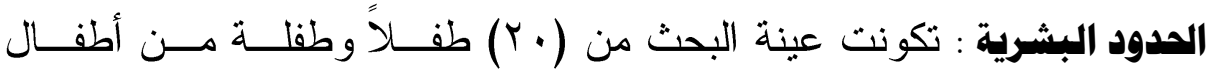

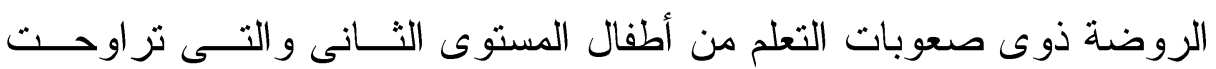
أعمار هم من بين ( 0-7 ) سنوات من أطفال المستوى الثانى تم إختيــار هم

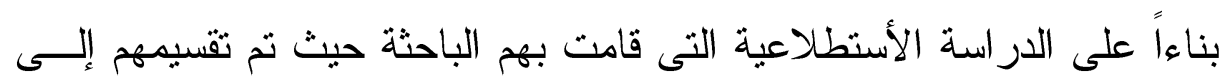
( ( () أطفال من المجموعة التجريبية و ( (1) أطفال من المجموعة الضابطة . الحدود الموضوعية : يقتصر البحث على بعض خصــائص التفكيـر الإيجــابى وهى( حل المشكلات، التقة بالنفس، تحمل المسئولية ).

:

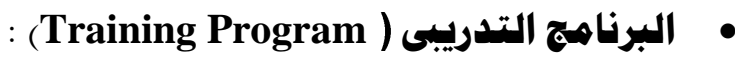

هوبرنامج يقدم للأطفال بهدف تتمية مهار اتهم على أسس ومبادىء تتحدد

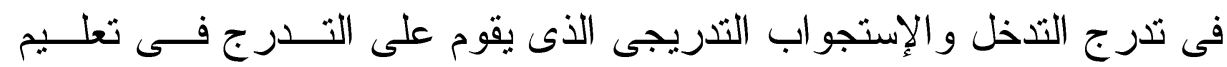
الأطفال المعرفة و السلوكيات الصحيحة و التمييز بين الســلوكيات الصـــحيحة و الخاطئة فى إطار صيغ إستفهامية .

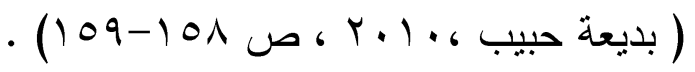

\section{• • (Positive Thinking) :}

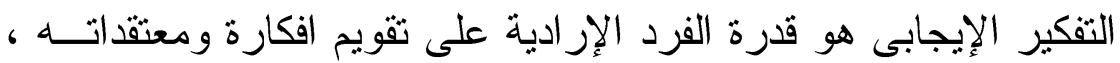
و التحكم فيها وتوجيهـا تجاه تحقيق ما توقعة من النتائج الناجحة ، وتدعيم حل المشكلات ، ومن خلال تكوين أنظمة و أنساق عقلية منطقية ذات طابع تفاؤلى مأى تسعى إلى الوصول لحل المشكلات باستخدام قناعات عقلية بناءة ، وباستخدام استر اتيجيات القيادة الذاتية للتفكير ، ولتدعيم ثقة الفرد فى النجاح من خــلال تكوين انظمة عقلية منطقية ذات طابع تفاؤلى .

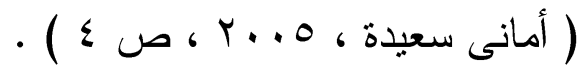

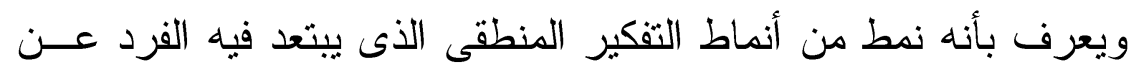
التفكير الهدام ، و التى تحمل بعض المعتقدات التى توجه الأفكار إلى المشاعر 


\section{فاعلية برنامج تدريبى لتنهية بعض خصائص التفكير الإيجابى}

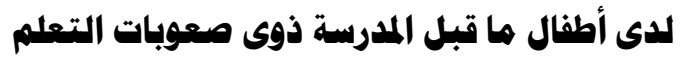

السلبية و السيطرة على توجيه المشاعر و المبالغة فى رؤية الخطأ و النظر إلـى العيوب . (Stallard,P.,2002) ( )

التعريف الإجرائى للباحثة :

التفكير الإيجابى هو نمط من أنماط التفكير الفعال يستطيع الطفـلـل مــن

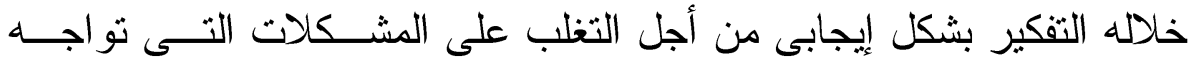

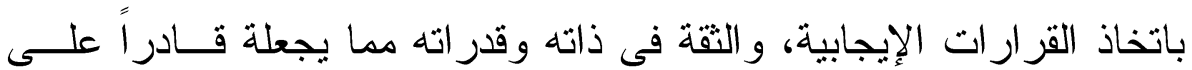
تحمل مسئولية تصرفاته

\section{صعوبات التعلم (learning disabilities) :}

يعرفها سليمان عبد الواحد على أنه "مصطلح يشير إلى مجموعة غيــر

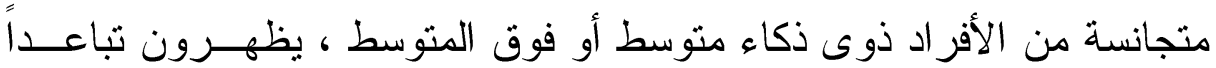

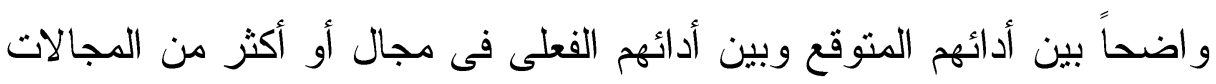

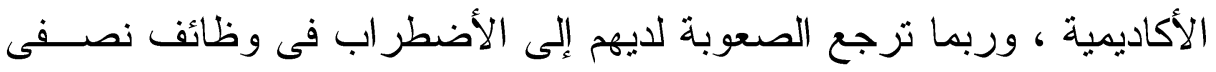

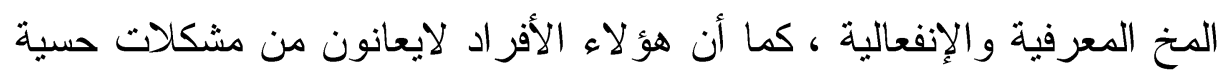

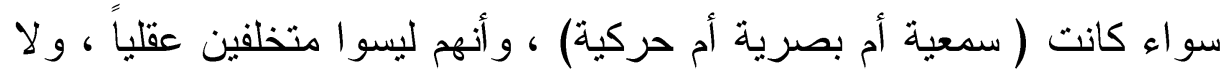

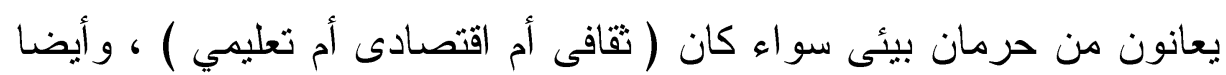

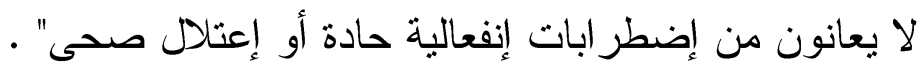

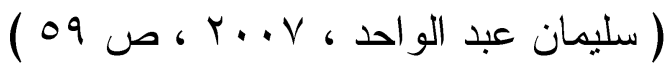

\section{التعريف الإجرائى للباحثة :}

صعوبات التعلم هى عبارة عن مجموعة غير متجانسة من الأفراد تعبر عن نفسها عن طريق صعوبة نمائية أو أكاديمية أو إجتماعية ، قد ترجع إلى مأى إضطر ابات وظيفية فى الجهاز العصبى المركزى يمكن أن يحدث على إمتداد حياة الفرد و أنهم ليسو ا متخلفين عقليا ولا يعانون من حرمان بيئى سواء كان

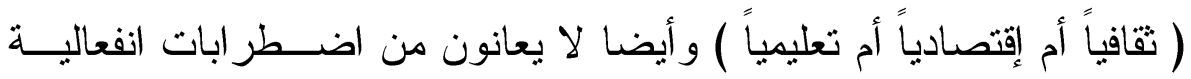


حادة أو حرمان حسى وتلك الصعوبات ينتج عنها حدوث بعـض المظـــاهر الاجتماعية والانفعالية و السلوكية تجعلهم مختلفين عن أقرانهم من العاديين .

الإطار النظري : ويتضمن هذا الإطار ما يلي :

\section{المبحث الأول التفكير الإبمابى : الإصنى \\ أولاً : هفهوم التفكير الإيجابى :}

التفكير الإيجابى عادة عقلية يمارسها الفرد بصورة لا شعورية تقوم على استغلال الطاقات والإمكانات الكاملة لدى الفرد ، ويقوم التفكير الإيجابى على التى قدرة الفردعلى بناء وتتظيم افكاره ومعارفه وخبر اته ، و الأختيار من بينها ما يلائم الموقف الحالى ، وتركيز شعوره ، وتوجيــه ســلوكياته نحـــو تحقبــق الأهداف التى يسعى إليها و التخطبط الجيد للمستقبل ( إبر اهيم الفقى، 9 . . ب ) .

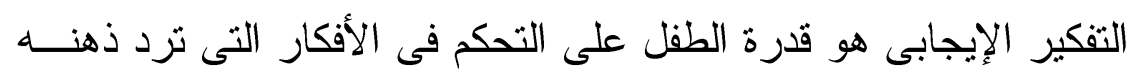

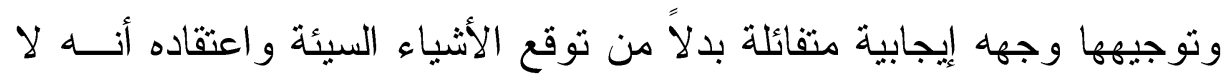
يوجد حل لما يواجهه من عقبات ومشكلات ، فالتفكير الإيجابى هو أن يفكـر

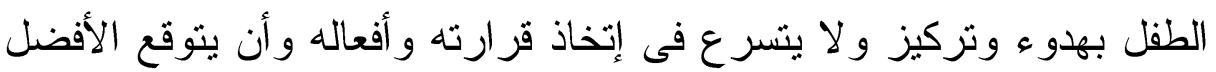

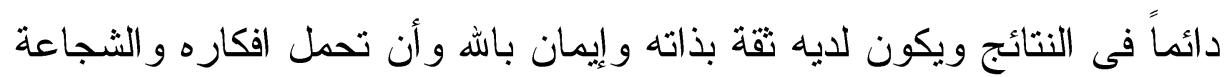
و الحماس و التصميم على مواجهة أى موقف أو صعاب تو اجهه بما يتفق مع ما تعلمه من أخلاقيات

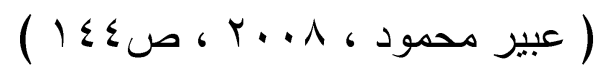

ثانياًا : أهميهة التفكير الإيبابى : التفكير الإيجابى هو حب الذات :

إن الطفل بحب نفسة إذا أحبه و الداه وهو يحب من يعطف عليه ، ومــن

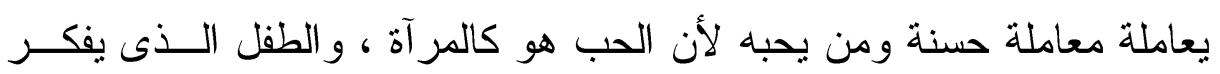




\section{فاعلية برنامج تدريبى لتنهية بعض خصائص التفكير الإيجابى}

لدى أطفال ها قبل المدرسة ذوى صعوبات التعلم

تفكير اً إيجابياً ، يكون ذلك نتيجة إضفاء و الديه الحب و الحنان عليه و التقــدير و الاحتر ام لأر ائه وتعزيز اعماله و افعاله تعزيزاً إيجابياً .

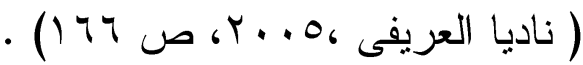

ولكى يتم حديث النفسى الإيجـابى وحب الـذات لـدى الطفل فالأبـد هـن توافر الذات الأيجابية فهناك بعض الأساليب أشسارت إليهـا الباحثـة تعمسل على تنمية مفهوم إيبابى نهو الذات للطفل :

- ت تمو الذات الأيجابية عن طريق التفاعل الطبيعـى الســوى مـــع الطفـل وبتمكينه من التعبير الصريح عن الرأى وبمساعدتة فــى اتخــاذ القــرار اللازمة وبتدريبة وتوجيهه فى ذلك وبإتاحسـة الفرصــة أمامسـه للتــدخل و الإيجابية وبتعزيز استجاباته الناجحة ومبادر اته الصحيحة وبالعمل علـى إشعاره باستمر ار الحب و العطف و الحنان و الأحتر ام و الثقة المتبادلة ، و عن الإستماع إليه وفهم تصرفاته و أفعاله ، وبتحديد دورة ومكانته فى الحياة . - و الأشخاص المهتمون فى حياة الطفل يجب أن يســاعدوه علــى تأســـس مشاعر إيجابية عن جسده ومظهره و التثى يتم رؤيته من قبل الآخــرين ،

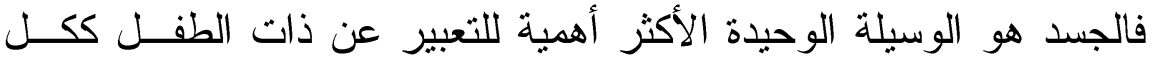
ويتكون لايه مفهوم ذات إيجابى عندما يشعر بانه كفء جسمانيا وســوف

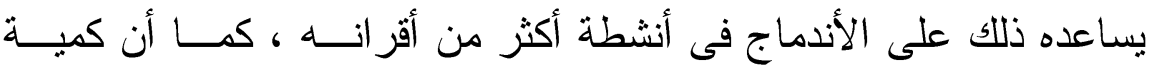
ونو عية القبول الذى بيديه الو الدان و الإستحسان ، يحدد إلى حد كبير صور الأطفال عن أنفسهم ، فالأطفال يميلون إلــى إدر الك استحســـان الوالــدين و أهتمامهم كمؤشرات عن أهميتهح ودلالتهم ، وباستمتاعهم بهـذذه الــدلائل

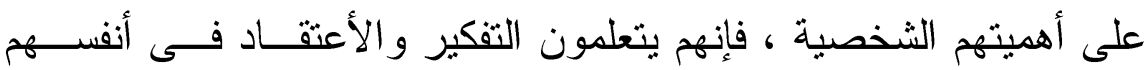
بطريقة إيجابية ، فالأهتمام الوالدى يرتبط بشكل إيجابى بمفهـوم الــذات 
و المحبة الو الدية ومفهوم ذات الطفل هى أحد النتائج الأكثر اتساقاً مع بحث تأثير الأسرة على تكوين مفهوم الذات .

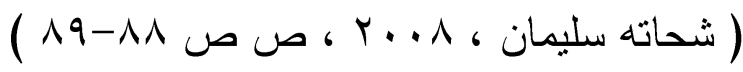

و هذا يتفق مع در اسة (Burnett,p,1994) و التى توصلت نتائجها إلـى إرتباط الحديث النفس الإيجابى إرتباط إيجابى بالثقة بالنفس والإرنباط السلبى

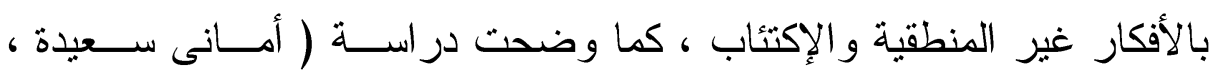

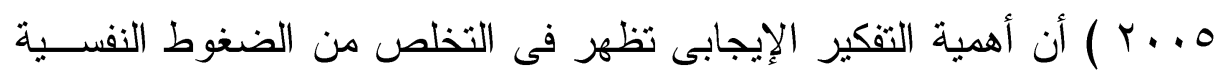

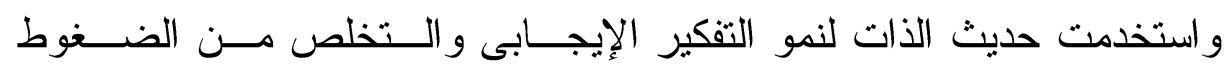
النفسية ، ودر اسة (Caprara, G., \& Steca, P. ,2006.p.603 ) بعنـــوان فعالية الذات التنظيمية فى إدارة الإنفعالات و العلاقات الأسرية بالتفكير الإيجابى و السعادة حيث تهدف إلى دراسة نموذج مفاهيمى يستتد إلى دوراً حاسماً فـى لـى إلى

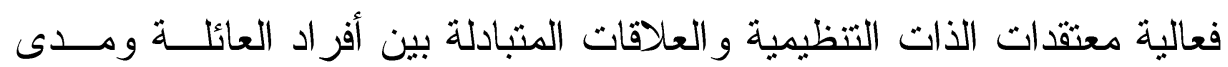

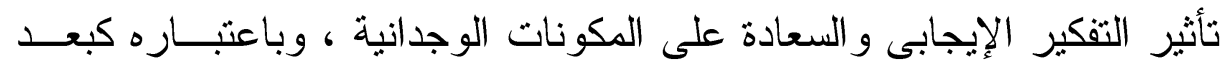
كامن يشكل الرضا عن الحياة و الثقة بالنفس وتقدير الذات و التفاؤل ، وقد أثبتت نتائج الدراسة وجود تأثير لكل من فعالية الذات فى إدارة الإنفعالات و العلاقـــة المتبادلة بين أفر اد العائلة على التفكير الإيجابى و السعادة . كما هدفت در اسة(Lightsey Jr, O., \& Boyraz, G., 2011.p.203) إلى فعالية الذات التى تعتبر أحد أهم محددات التفكير فالأفر اد ذوو فعالية الذات المرتفعة يميلون إلى التفكير الإيجابى فى حين الأفــر اد ذوو فعاليــة الـــات المنخفضة يميلون إلى التفكير السلبى ويتصفون بعدم القدرة على التحدى . التفكير الإيجابى هو هرآه الصحة : فصحة الجسد تعتمد على كل ما يصدرمن أفكار من الدماغ و وأحاســبس : من القلب ، فإذا كانت تلك الأفكار سلبية وكانت الأحاسيس تميل إلى الإكتئاب 


\section{فاعلية برناهج تدريبى لتنمية بعض خصائص التفكير الإيجابى}

لدى أطفال ها قبل المدرسة ذوى صعوبات التعلم

فهنا تتأثز صحة الجسد فيصبح عليلاً ، فصحة أطفالنا الجسدية تعتمــد علـى صحتهم النفسية و التى هى نتيجة وجود تفكير و أحاسيس إيجابية لديه .

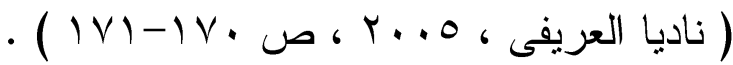

ويشير Trujillo,F.,2005.p.116 ) إلى أن إيجابية التفكير للأطفــال فن وعلم ، وأن هناك بعض العناصر للأبوه و الأمومة التـى تحــدث فــرق فى المساعده على تشكيل الحياة الإيجابية ، لأن التفكير الإيجابى جانب هـام لإنقاذ الأطفال فى كل الظروف ومن خلال ذلك يتم الدعم والتنمية الصـــية ،

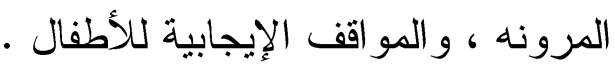

\section{التفكير الإيجابى هو هفتاح الثقة بالنفس والسعادة :}

يشعر الطفل بالسعادة تغمرة لأنه يبدأ بالتفكير الإيجابى تجاه نفسه ذلك ، هاده :

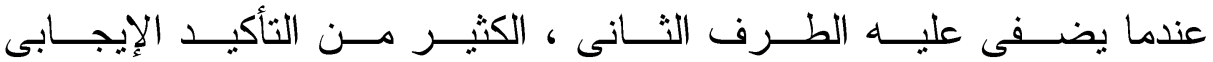
من كلمات المدح و الأطر اء و الأعجاب فيبدأ يرى نفسة مسـن Affirmations منظار أخر ، منظار الثقة بالنفس وبالتالى يبدأ فـى حبـــه لنفســهـ وبـــالتفكير

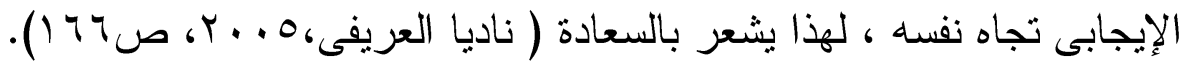
ويتفق ذلك مع در اسة (Caprara,G,eta al.,2006.pp30-34 ) التى بعنوان سعادة المر اهقين ومعتقدات الكفاءة الذاتية كمحددات للتفكير الإيجــابى و السعادة و التى هدفت إلى تحديد الخصائص الشخصية و المسار ات النمائية إلى التكيف الناجح من مرحلة الطفولة إلى مرحلة البلوغ حيـــث إهتمــث بأهميــة تحقيق الكفاءة الذاتية وتفعيل التفكير الإيجابى كالثقة بالنفس و التفاؤل و السعادة و الفرف بين التأثير ات الإيجابية والسلبية وكانت من أهم نتائجها تأثثير المعتقدات بهات

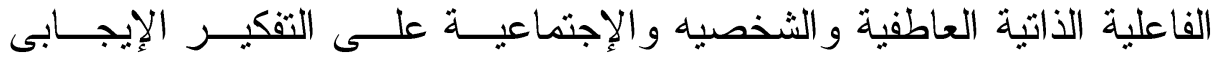

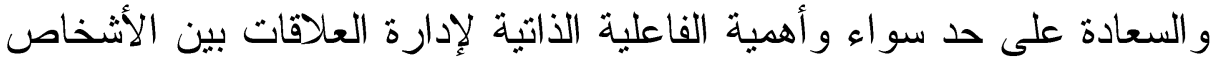
و المشاعر الإيجابية و السلبية فى تعزيز الثوقعات الإيجابية حــول المســثقبل 
و الأحتفاظ بالذات العالية والشعور بالإرتياح و الرضا وتجديد العو اطف بــأكثر

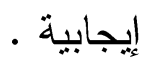

ودر اسة (Froh, J,et al.,2014.p.132) أن التفكير الإيجابى ضروري للحياة الإجتماعية و التو افق مع الآخرين وقدأجريت هذه الدراسة على مجموعة من الأطفال ممن تتر اوح أعمار هم ما بين

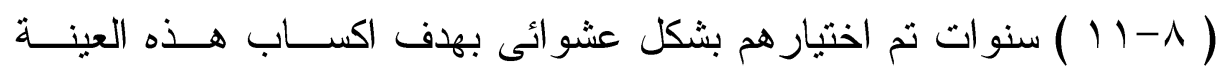
مبادىء التفكير الإيجابى ، وتتمثل فى اختيار العبار ات الايجابية التي تســاعد

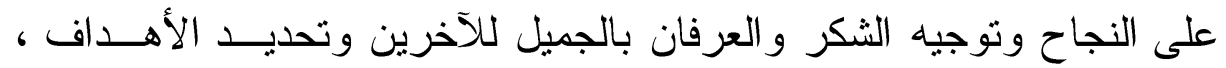
وترتيبها حسب أولويتها ، وتحديد وسائل تحقيقها و البعد عن التشاؤم وتبـــادل

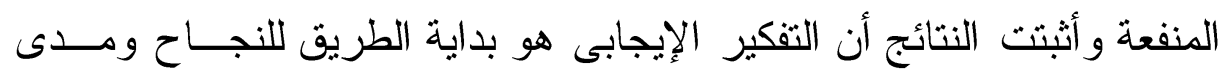
التحسن الحياتى والتاثير الإيجابى فى كافة المجالات الحياتية حيث يؤدي إلـى إلى

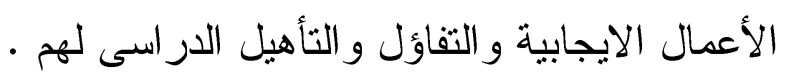

\section{ثالثًا : خطوات التفكير الإيجابى :}

وهناك بعض الخطوات التى تساهم فى زيادة الأفكار الأيجابية :

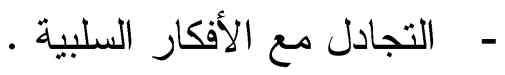

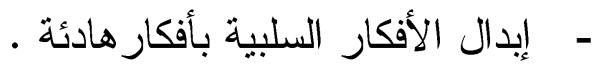

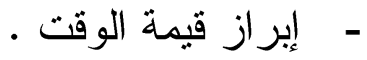
- التفكير حول الأفكار و الأفعال .

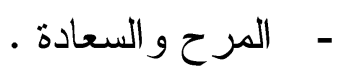
- - تشكيل الأفكار ومدح النفس - - تصور مستقبلاً إيجابياً .

- التصرف بشكل طبيعى باستخدام معايير مرنة . - - السيطرة على الغضب . - ل - عدم النقد للذات و الثناء على النفس . 


\section{فاعلية برناهج تدريبى لتنمية بعض خصائص التفكير الإيجابى}

لدى أطفال ها قبل المدربة ذوى صعوبات التعلم

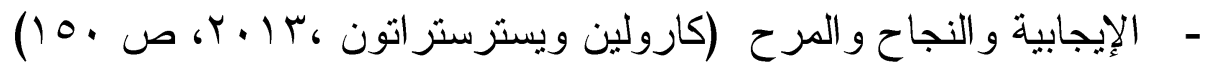
وبناءأعلى هذه الخطوات السابقة للتفكير الإيجابى يمكن تتمية مهــار ات

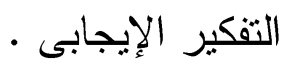

\section{رابعًا : ههارات التفكير الإيجابى :}

- الرغبه المشتعلة هى التى تجعل الأمور التى نريد فعلها مسيطرة دوماً على :

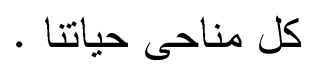

- القرار القاطع بوضع الأشياء التى نريدها فى الفعل و إتخاذ القــرار بـــلك .

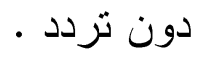

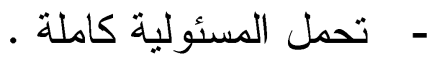

- الإدر الك الو اعى للقدر ات و إستخدامها إيجابياً يجعل من الحياة تجربة مــن

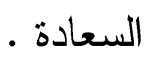

- تحديد الأهداف بكل مناحى الحياة حيث التخطبط المسبق لها . - التأكيدات المتضامنة الإيجابية . - الوقت الإيجابى من خلال تخصيص وقت للتفكير الإيجابى . - - التنمية الذاتية بالقر اءة و الإطلاع - الإهتمامات الشخصية و النشاطات اليومية .

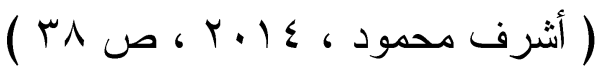

بالإضافة إلى بعض الدراسات السابقة التى وضحت بعـض مهــار ات التفكير الإيجابِ المتمثلة فى حديث الذات الإيجــابى ، و التخيـلـل ، و التوقــع الإيجابى للأحداث ومن أهمها در اسة ( أمانى سعيدة ، 0. . . ) و التى بعنوان

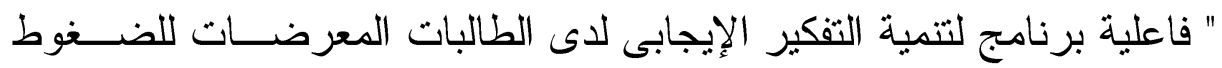

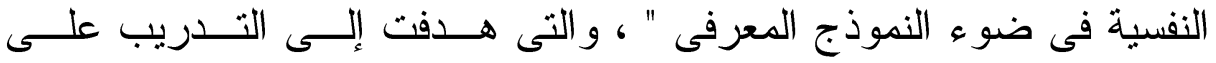




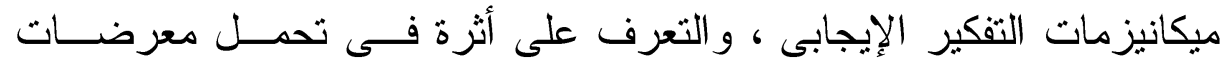
الضغوط النفسية أو التخفيف منها أو إمكانية حلها ، فقد توصلت الدراسة إلـى لـى فاعلية البرنامج المقتر ح فى تخفيف حدة الضغوط لدى طالبات الجامعسـة مــن خلال ميكانيزمات التفكير الإيجابى ومن أهمها الحديث الإيجابى للذات . ودراسة ( أحلام عبد الستار ، 1) (1) ) بعنوان : فاعلية برنامج تدريبى لمهار ات التفكير الإيجابى وأثزه فى تتمبة بعض الخصائص النفسية و العقلبـة لدى الأطفال ، حيث هدفت إلى إعداد برنــامج تــدريبى لمهــار ات التفكيـر الإيجابى لأطفال ما قبل المدرسة فى تتمية بعض الخصائص النفسية و العقليـة لاى أطفال ماقبل المدرسة ، وتوصلت نتائج الدراسة إلى فاعليــة البرنــامج التدريبى فى تنمية مهار ات التفكير الإيجابى ( حديث الذات - التخيل- التوقع الإيجابى ) ، كما توصلت إلى وجود تأثير دال إيجابياً لبرنامج تتمية مهـار ات التفكير فى تتمية بعض الخصائص النفسـية ( التقــة بــالنفس ـ التهــاؤل ) و الخصائص العقلية ( الطلاقة- الأصالة- المرونة ) .

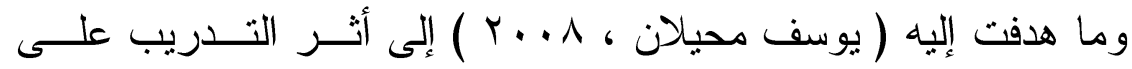

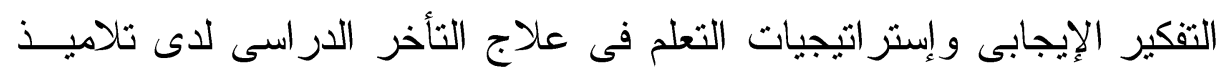
الصف الرابع الإبتدائى فى دولة الكويـــ ، و واســتخدمت الدر اســـة الأدوات الأتية : إختبار التفكير الإيجابى ، ومقياس إستر اتيجيات التعلم المنظم ذاتيــاً ، و إختبار التعلم التعاونى ، و البرنامج المقترح حيث توصلت نتائج الدراسة إلى لى إلى أثز البرنامج التدريبى فى تنمية التفكير الإيجابى ( الحديث الإيجابى للذات - التخيل ) ودر اسة (Garry,M.,1996,p. 208-2014) و التى هدفت إلى التعرف على تخيلات الأطفال وأثر ذلك على المستقبل ، حيث إبــتخدمت الدراســة 


\section{فاعلية برناهج تدريبى لتنمية بعض خصائص التفكير الإيجابى}

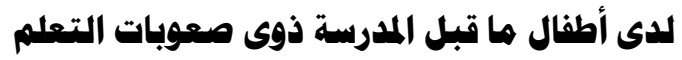

بعض المواقف الخيالية للاحداث الماضية فى الطفولة ، وتوصلت الدراسة إلى أن التخيل يؤدى إلى تغير ات إيجابية فى الأحداث ، ويزيد تخيل الحدث الغيــر حقيقى من وقوع الحدث و احتمالية وقوعة فى المستقبل ، تأكيد طلاب العينــة

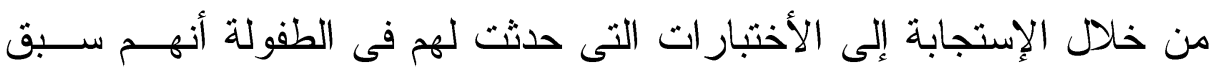
كانو ا يتخيلونها وحدثت لهم بالفعل . خصائص التفكير الإيجابى :

يصف هرتزل Hartzel,Cary (. . . ب) الإيجابية بالخصائص التالية :

( الإيجابيون يبحثون عن الفرص المناسبة للتغيير • r) الإيجابيون لديهم دافعية إنجاز عالية تساعدهم على تغيير وتوجيه الأهداف و إنهم يركزون بعملهم ويوجهون مسئوليتهم المحددة بطريقة فعالة ويقومون بذلك بكل ما يملكون من قوة ويبذلون قصارى جهدهم رغم كل الصعوبات

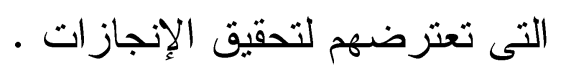

r) الإيجابيون يستيقون الأحداث ويستتطقونها وبذلك يتفادون المشــــل قبـلـل

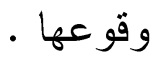

ع) الإيجابيون مجددون ومجودون يفعلون الأشياء بطرق مختلفة .

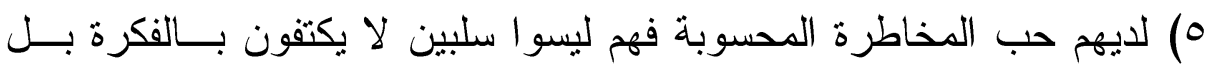
يقومون بتجريبها و لا يترددون بأخذ الدور القيادى .

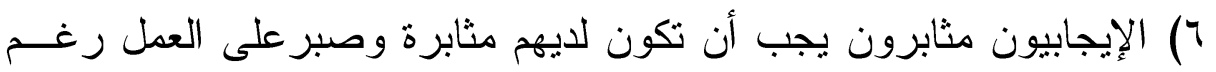
صعوبته ولكن شريطة الا يكونو ا متصلبين وجامدين • V الإيجابيون يحققون النتائج على المستوى الشخصــى وعلــى المســـويين الإحصائى و البيئى فالشخص الإيجابى إن وجد فى مجموعة ما تكون نتائج عمله مؤثزة فى العملية بشكل عام .

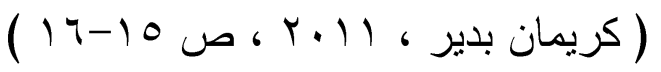




\section{ويمكن أن نمدد خصائص المتعلم الإيجابى فيسها يلى :}

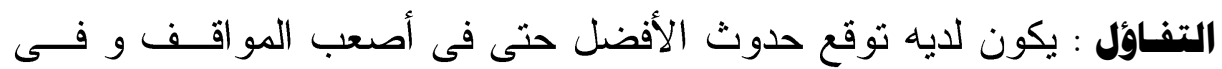

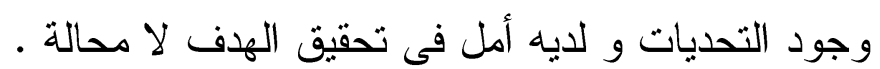

الصمساس : يمتلك مستوى مرتفع من الاهتمام و الطاقة مع إحســاس بالــــأداء المستحدث ذاتياً .

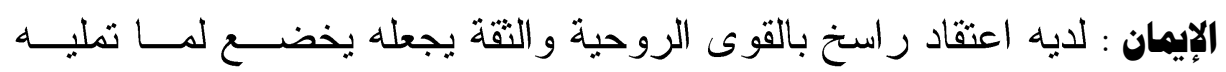
قو انين الأداء و العمل .

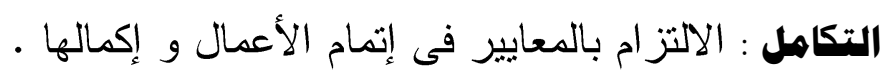
الشجاعة : لله إر ادة قوية و حب مغامرة لقهر المخــاوف المرتبطـــة بإنجــاز

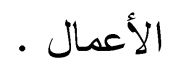

الثقة : القناعة بإمكاناته و قدر اته و خوض الأعمال دون تردد

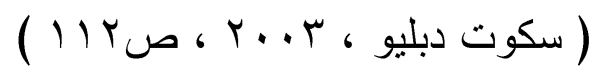

حيث حددث در اسة (Kimbrough Jr, R.,1997.pp.9-13) بعـض السمات الشخصية لأصحاب التفكير الإيجابى ومن أهم هذه الصفات القيــادة ، و القدرة على إتخاذ القرارات الإيجابية ، و القدرة على حل المشكلات بايجابية ، و الحس السليم و الشجاعة ، و الثقة بالنفس ، و الرعاية ، و إحتر ام الذات .

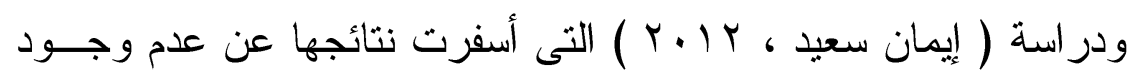
فروق دالة إحصائياً بين متوسطات رثب درجات أطفال المجموعة التجريبــة فى التطبيقى البعدى و التتبعى للبرنامج الإرشادى القائم علــى إســتراتيجيات التفكير الإيجابى على مقياس المشكلات السلوكية . كما هدفت در اسة ( أسماء محمد ، ع ا. Y ) إلى الكثف عن أثر برنامج تدريبى قائم على مهار ات التفكير الإيجابى فى تتمية بعض سمات الثخصية ، وحل المشكلات الحياتية لدى تلاميذ الإعدادية ذوى صعوبات التعلم ، وتتبـع 


\section{فاعلية برناهج تدريبى لتنمية بعض خصائص التفكير الإيجابى}

لدى أطفال ها قبل المدرسة ذوى صعوبات التعلم

أثز البرنامج التدريبى لتنمية بعض سمات الثخصية ( الثقة بالنفس ، التفاؤل ، المرونة ، حل المشكلات الحياتية ) لدى أفر اد العينة . و در اسة (سالم حسين ، ع ا · ) ) إلى أن التفكير الإيجابى له أهميته فى حياة الفرد ، فالتفكير الإيجابى يكسب الفرد الثقة بالنفس و التفاؤل فى المستقبل وسعادة فى الحياة ويستطيع الفرد أن يتغلب على العديد من المشــكلات التـى تو اجهه ، لذلك على الفرد أن يعمل علــى اكتســاب إبــتراتيجيات التفكيـر الإيجابى ، وزيادة النواحى الإيجابية فى شخصيته و العمل على توكيد الذات ،

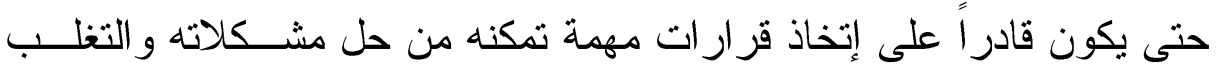
على عثر اته ، إستتاداً على قدر اته و على تفكيرة الإيجابى . مما سبق فقد حددت الباحثة من خلال عرض بعض در اســات التفكيـر الإيجابى بعض الخصائص التى بمكن تتميتها للأطفال ذوى صعوبات الـتـعلم مثل ( تتمية القدرة على حل المشكلات ، و الثقة بالنفس ، وتحمل المسئولية ) .

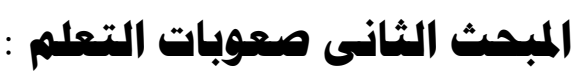

\section{تعريف الهيئة الوطنية المشتركة لصعوبات التعلم (1911) :}

\section{National Tianal Joint Committee on Learning Disabilities (1981)}

تعرف صعوبات التعلم " مصطلح عام يشير إلى مجموعة غير متجانسة من الإضطر ابات تظهر من خلال صعوبات واضحة الدلالة فـى الأكتشـاب و استخدام قدر ات الأستماع و الكلام و القر اعة و الكتابة و الحساب و التفكير و هــذه وله الإضطر ابات داخلية intrinsic عند الفرد وتحدث طو ال الحياة ، وقد تــرتبط

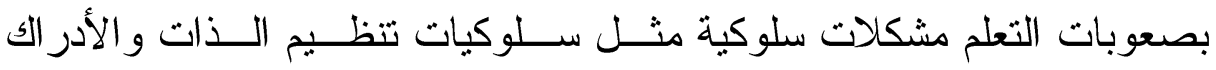
الإجتماعى Social Perceptual و التفاعل الإجتماعى Social interaction إلا أنها لا تشكل فى حد ذاتها صعوبات تعلم ، ومع أن صعوبات قــد تحــدث 
متلازمة مع الإعاقة الأخرى كــالتخلف العقلـى أو الإضـــر ابات الحســية و الإنفعالية أو عو امل خارجية مثل التّريس غير الفعال إلا أنها لبست ناتجــة عن هذه التأثير ات

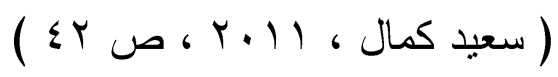

تعريف اللجنة القوهية ( الوطنية ) المشتركة (1998) ( NJCLD)

National Joint Committee on Learning Disabilities (1994)

وينص على أن " صعوبات التعلم هى عبارة عن مجموعة غير متجانسة

من الإضطر ابات تعبر عن نفسها عن طريق صعوبة ملحوظة تكتســب فـى في

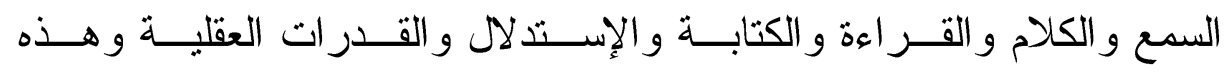
الإضطر ابات ، قد ترجع إلى اضطر ابات وظيفيــة فـى الجهــاز العصـــى

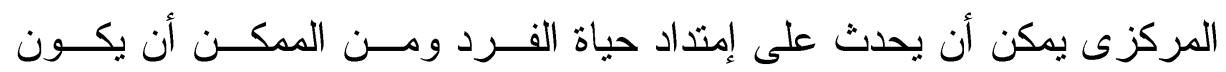
مصحوباً باضطر اب فى السلوك و الإدر الك الاجتماعى .

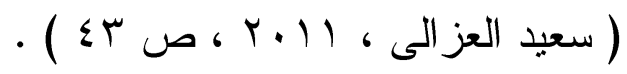

وبناءأ على التعريفات السابقة ويلاحظ على أذها إشتـملت على الأتى :

- صعوبات التعلم مجموعة من الصعوبات غير المتجانسة ، و المصابون بها

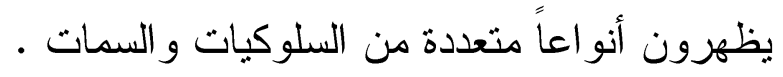

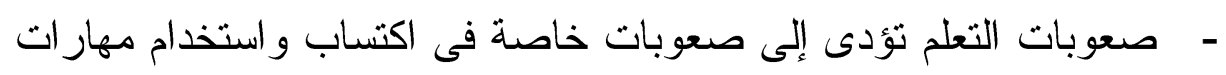

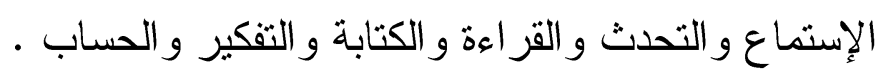

- - ترجع صعوبات التعلم إلى عو امل داخلية أكثر من أية عو امل خارجية .

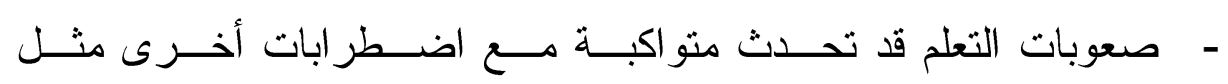
الإضطر ابات الإنفعالية

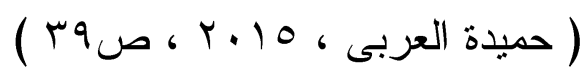

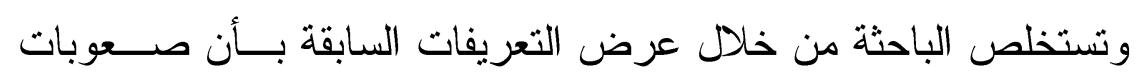
التعلم تظهر على مدى حياة الفرد ، فهى ليست قاصرة على مرحلــة عمريــة 


\section{فاعلية برنامج تدريبى لتنهية بعض خصائص التفكير الإيجابى}

لدى أطفال ها قبل المدربة ذوى صعوبات التعلم

معينة منل مرحلة الطفولة ، أو الثباب وأن أغلب التعريفات تضمنت بعـض أن النقاط التى أتفقت عليها ويتم تلخيصها على النحو التالى :

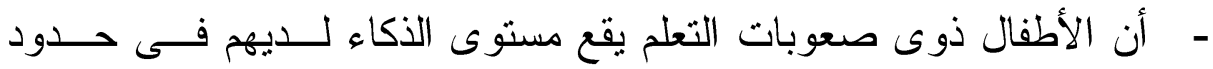

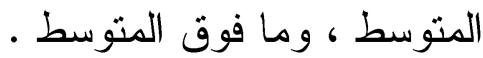

- أن صعوبات التعلم إعاقة مستقلة كغيرها من الأعاقات الأخرى ، تختلـــ في درجتها وشدتها .

- تظهر صعوبات التعلم بين الأوساط المختلفة تقافياً و إقتصادياً وإجتماعياً . - تظهر صعوبات التعلم فى واحدة أو أكثر من العمليات النفسية والفكريــة مثل صعوبة الانتباه ، و الذاكرة ، الأدر الك ، التفكير ، و اللغة الثفهية . - أنها ليست نتيجة لإعاقة عقلية أو حسية أو بصرية أو سمعية أو حركية ، أو الإختلافات البيئية و الثقافية .

- كما أنها تؤثز على مختلف جو انب و أنشطة الحياة المتعددة والمختلفة . وقد أوضح ( Learner,j,2000,p.12) بأن الأطفال ذوى صعوبات التعلم يعانون من بعض المشاكل المتعلقة بالتعلم ، فقد تكمن مشكلة طفـلـل مـــا فــى بـى إكتساب مهار ات الكلام ومهار ات اللغة الشفهية ، وقد تكون مشكلة طفل أخـر فى القر اءة ، أو الحسباب ، أو الكتابة اليدوية ، أو المهــار ات الحركيــة ، أو التفكير ، أو القدرة على التعبير الثفهى و الغير شفهى . همكات تشخيص صموبات التعلم

\section{Criteria for diagnosis of Leaning disabilities}

\section{Discrepancy Criterion : همك التباعد أو التفاوت}

أى يستبعد الأطفال الذين لايهر عجز أو قصور يسبب لهم هذه الصــعوبات : هـات و هذا لا يعنى أنه ليس من المعاقين من يعانى من الصعوبات التعليمية غير أن هؤ لاء يحتاجون إلى بر امج خاصة تتاسب معهم •

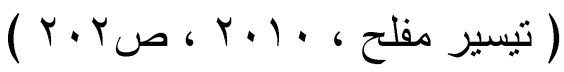


ويوضح هذا المحك أن الأطفال ذوى صعوبات التعلم يبدون تباعداً فـى .

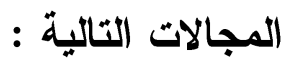
- التفاوت بين نسبة الذكاء و التحصيل الدراسى .

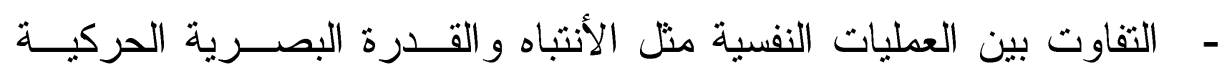
و الذاكرة وبين مستوى التحصيل الدراسى .

- - التفاوت بين التحصيل الدراسى الفعلى و الأداء المتوقع لهؤلاء الأطفال .

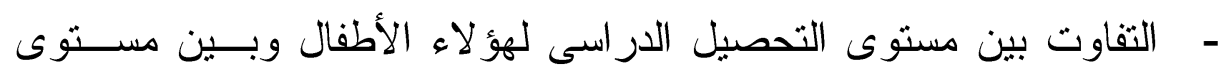

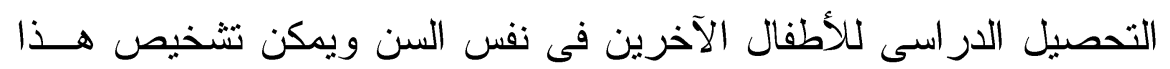
التباعد من خلال تطبيق الاختبار ات و المقاييس الخاصة بالـــكاء و القــدرة

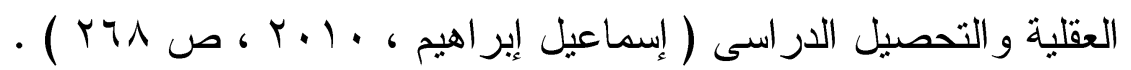

\section{Exclusion Criterion : همك الإستبعاد}

يقصد به إقصاء أو إستبعاد جميع الحالات التى يرجع تخلفها أو قصورها

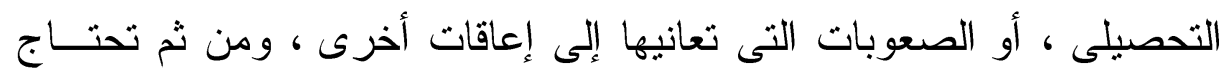

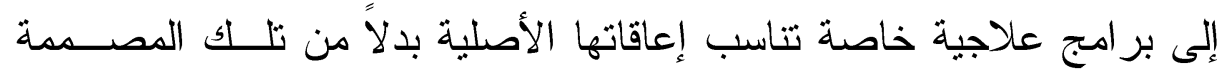

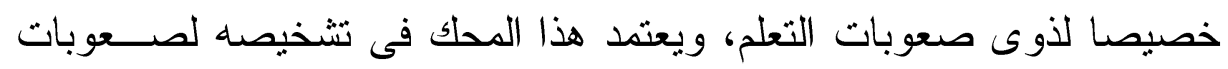
التعلم على إستبعاد الحالات التى يرجع السبب فيها إلى إعاقة عقلية أو إعاقات

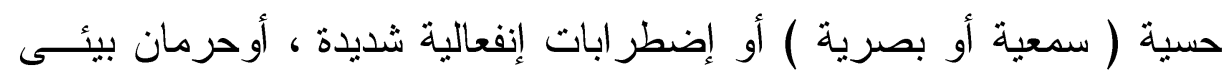

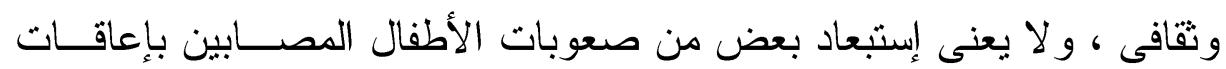

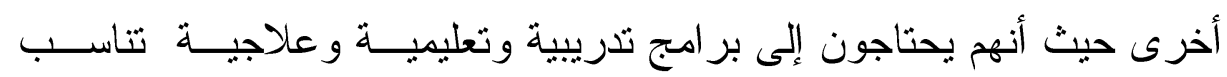

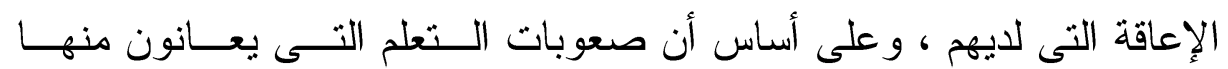

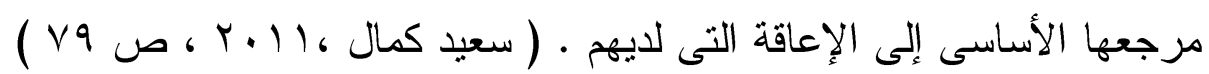
Special Education Criterion : همك التربية الخاصة فهذه الفئة من الأطفال تحتاج لطرق خاصة فى التعلم خصيصا لمعالجة

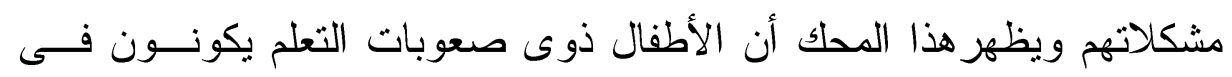




\section{فاعلية برنامج تدريبى لتنهية بعض خصائص التفكير الإيجابى}

لدى أطفال ها قبل المدرسة ذوى صعوبات التعلم

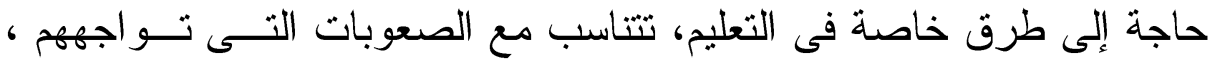
و هذه الطرق تختلف عن الطرق المتبعة فى التعليم مع الأطفــال العـاديين ،

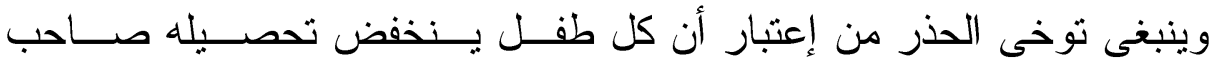
صعوبة ، فالطفل صاحب الصعوبة يتمتع بقدرة عقلية تقع ضمن المتوســط أو الأعلى فى الذكاء وأن إنخفاض تحصيلة لايرتبط بإعاقة عقلية أو جسـمية أو بو سمعية أو بصرية ، فى حين يرتبط التأخر الدراسى بقصور و إنخفاض نسـبة إنة الأكاء ، ولكى نقوم بعملية تحديد دقيق وتشخيص و اضـح مفصـلـل لصـــعوبات

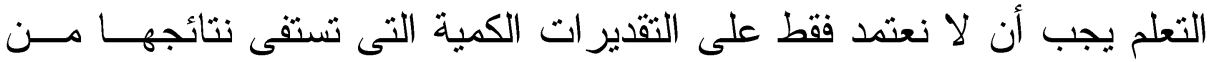

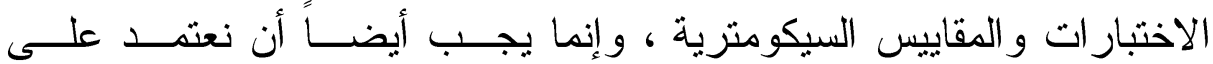
الملاحظات و الأحكام الإكلينيكية من المتخصصين و المهتمين بذوى صــعوبات التعلم ، إذ تزيد مثل هذه الملاحظات و الأحكام الإكلينيكية من فهينا المشكلة أو الصعوبة التى يعانى منها الطفل .

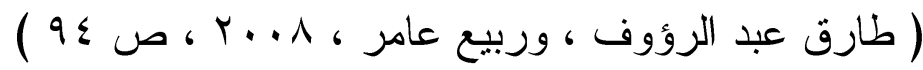

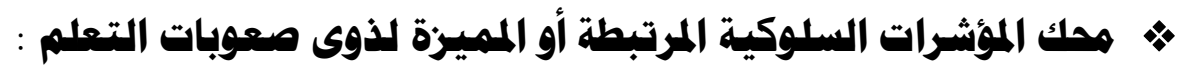
يقوم هذا المحك على أساس أن هنــاك خصــائص ســلوكية للأطفــال ذوى صعوبات التعلم مثل النشاط الحركى المفرط ، قصور الإنتباه ، الإحساس بالدونية يشيع تكر ارها لاى ذوى صعوبات التعلم ، ويمكن للمعلم داخل الفرص الدر اسى ملاحظتها ، ومن ثم القيام بالتصفية المبدئية و الكثف المبكر عن ذوى صعوبات التعلم وذلك بأستخدام مقاييس تقدير السلوك .

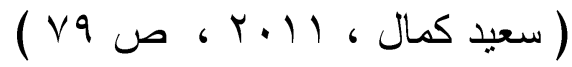

\section{Maturation problems همك المشكلات المرتبطة بالنضج} حيث نجد معدلات النمو تختلف من طفل لآخر مما يؤدى إلى صــعوبة

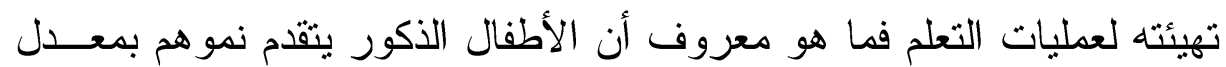


أبطأ من الأناث مما يجعلهم فى حوالى الخامسة أو السادسة غير مستبعدين أو مهيئين من الناحية الإدر اكية لتعلم التمبيز بين الحروف الهجائية فــى قــر اءة وكتابة مما يعوق تعلمهم اللغة ، ومن ثم يتعين تقديم بر امج تربويــة تصــحح قصور النمو الذى يعوق عمليات التعلم سواء كان هذا القصور يرجع لعوامـلـل ور اثية أو تكوينية أو بيئية ، ومن ثم يعكس هذا المحك الفروق الفرديـــة فــى

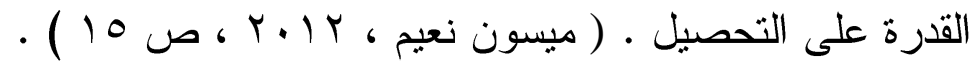

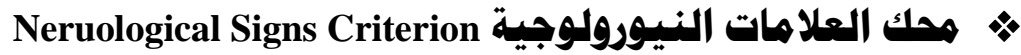

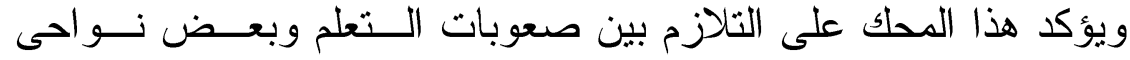

القصور العصبية Neurological Impairments لدى الطفل مــن قبيـلـل

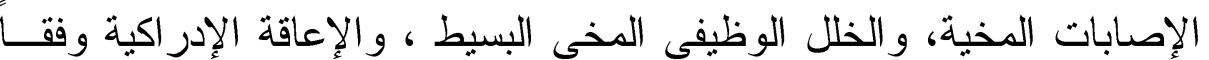
لما يتضمنه تعريف صعوبات التعلم من وجود إضطر اب فى واحد أو أكثر من العمليات النفسية الأساسية التى تدخل فى فهم أو استخدام اللغـــة المنطوقــة أو المكتوبة والتى ترجع إلى الظروف النمائية و لا تكون نتيجة لوجود إعاقـات ، وذلك على أساس أن المعرفة بالعو امل العصبية تساعد على تفهم أوجه القــوة و الضعف فى الناحية التعليمية لدى الطفل ( سرى محمد ، 10 . ب ، ص (17 )

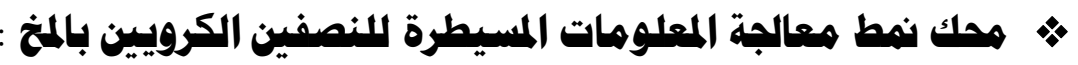
إن سيطرة وظائف أحد نصفى المخ الكرويين على الآخر يعد مؤشــرأ حقيقياً لوجود صعوبات تعلم لدى الأفراد وأن هذا المحك يمكن تطبيقة وتحقيقة عن طريق إستخدام مقاييس لأنماط التعلم و التفكير أومقاييس لأنماط معالجـــة المعلومات للنصفين الكرويين بالمخ .

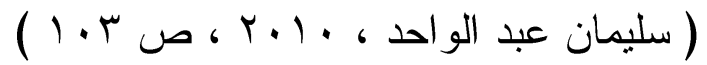

وفيما يلى عرض للأسباب التى تتضمنها كل عامل من العوامل المؤدية 
1) العواهل العضوية والبيهولوجية Biological and Organic Factors يعانى الأطفال ذوى صعوبات التعلم من تلف دماغى بسيط يؤثر علـى بعض جو انب النمو العقلى وليس جميعها ، و التلف الدماغى الثديد يؤدى الــى

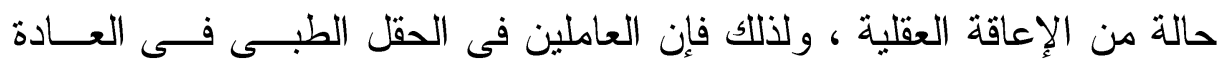
يشيزون إلى ذوى صعوبات التعلم على أنهم بعانون من تلف دماغى بســبط ،

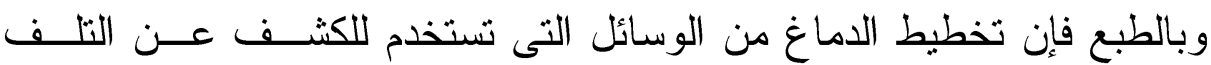
الادماغى ، وفى التخطيط الدماغى (eeg) (electroencephalograph) يتت رسم النشاط الكهربائى للاماغ على شكل موجات ، ويدل عدم الإنتظام فى تلك الموجات على وجود تلف فى خلايا الدماغ .

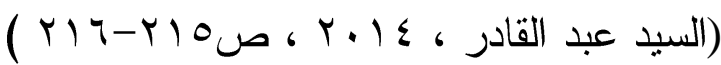

Genetic Factors العواهل الوراثية أو الجينية وفى هذا الصدد فإن هؤلاء الأطفال الذين يعانون من صعوبات التعلم لا لوأل يمكن القول بأنهم لا يمكنه الأنتفاع و الأستفادة من التعليم ، ولكن يعنى بـــأن هناك صعوبة أكبر لدى هؤلاء الأطفال للتعلم باستخدام طرق التدريس العادية التى يتم استخدامها عادة مع الأطفال الذين لا يتصفون بمثل هـــا الإســتـعداد و القابلية ، وبكلمات أخرى فإن هناك إلى تخطيط أكثر فــى التــدريس و إلــى

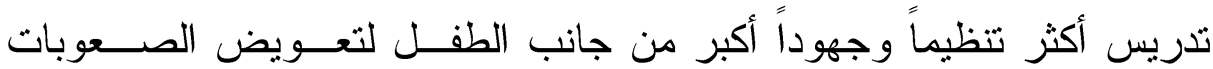

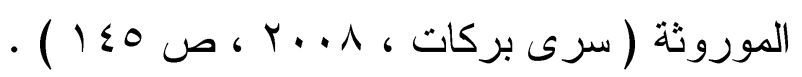

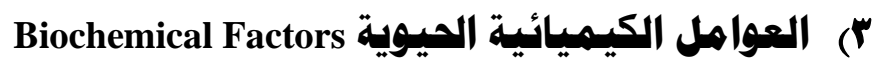
إن الأطفال ذوى صعوبات التعلم لا يعانون كثير أ من مشكلات معروفة فى النواحى العصبية أو حرمان بيئى ، حيث أن الجسم الإنســانى يفرزمـــواد كيميائية لكى يحدث توازناً داخل الجسم ، و هذا ما يطلق عليه بالكيمياء الحيوية

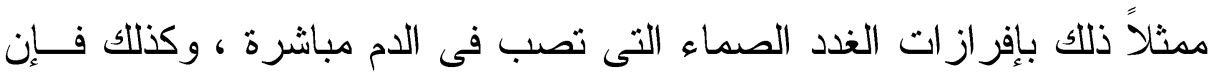


أى إفرازات زائدة فى الغدة الدرقية يؤدى إلى التخلف الدراسى ، بالإضافة إلى الى التى

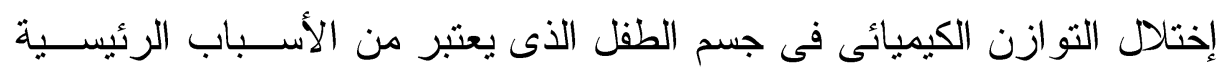

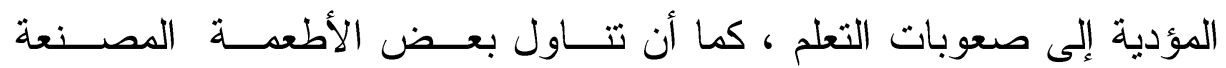

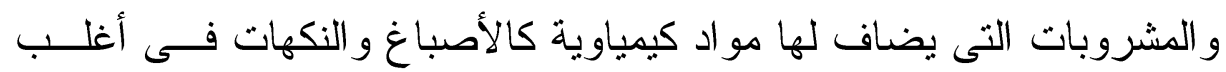
أطعمة الأطفال الصغار ، خاصة أعمار الو لادة وحتى سن عامين تسبب سرعة

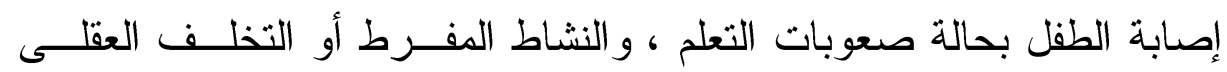

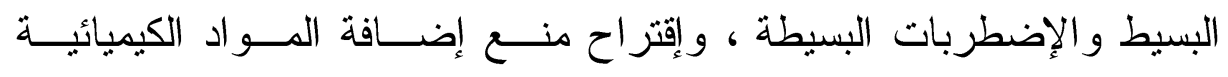

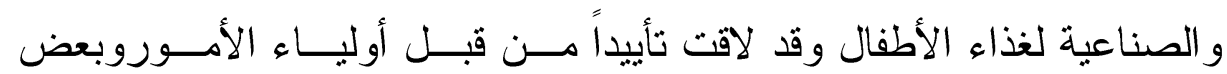
الجمعيات المهتمة بالطفولة ، فقد تحدث صعوبات التعلم نتيجة تـدفق الــدم

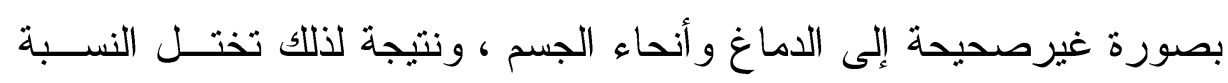
الطبيعية للفيتامينات الموجودة فى الدم فتترسب فى مكونات الدم .

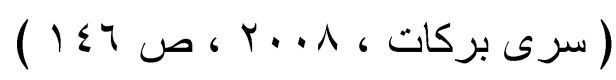

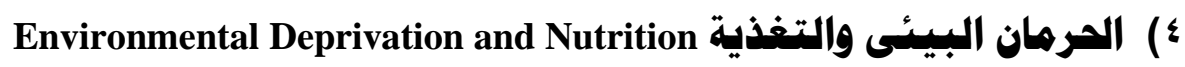
أن نقص التغذية و الحرمان البيئي لهما تأثير أ كبير اً على معاناة الطفل من

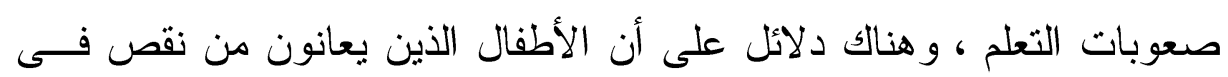

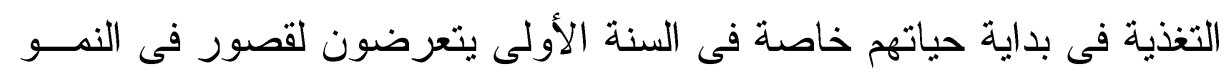

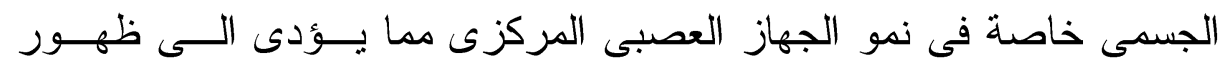
صعوبات فى التعلم لديهم كما أن الكثير من أطفال الطبقات الإجتماعية الفقيرة يعانون من قصور المهار ات اللغوية الأساسية عندما يدخلون المدرسة وأن هذا القصور يؤثز على مهار ات القراءة و الكتابة و الحساب .

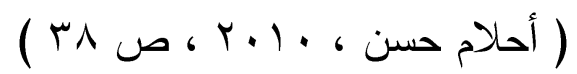

وذلك وفقا لما يشير إليه (Hallahan\&Mock,2010, P51) أن البيئة لها تأثير ات تتخذ أشكالاً يحتمل أن تسهم فى صعوبات التعلم وهذه الآثار تضم

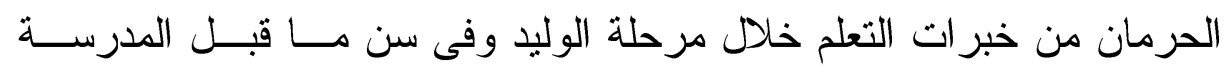




\section{فاعلية برنامج تدريبى لتنهية بعض خصائص التفكير الإيجابى}

لدى أطفال ها قبل المدرسة ذوى صعوبات التعلم

وكذلك المعلمون الذين ليس إهتمام بهؤلاء الأطفال بســهون فــى أســـمرار الإخفاق المدرســى والتحصــيل فـى (Hallahan\&Mock,2010, P51)

\section{العواهل البيئية Environmental Factors}

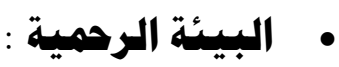

هى البيئة التى ينمو فيها الطل منذ الأخصاب وحتى الو لادة ومن العوامل السلبية المؤثرة فى نموه سوء تغذيى الام الحامل ونقص الرعايــه الجســـية

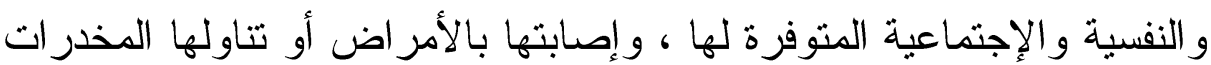
أو تعرضها للأشغاع أو العقاقير دون إشر اف الطبيب جميع هذه العو امل تعوق النمو الطبيعى للطفل ، و إكتساب خبرات تربوية فيما بعد .

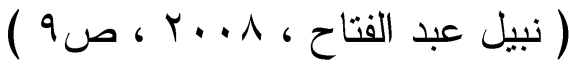

وضح (Campbell,C,2005,pp.43-50) أن هذه البيئة هى البيأـــة التى ينمو فيها الجنين وأن تلك الأغشية الرحمية التى تحيط بالجنين مسـئولة عن حماية و المحافظة علية و على نموه ، فهناك بعض العو امل التى تــنعكس

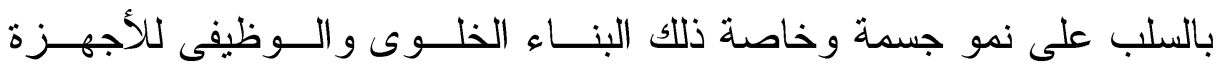
العصبية مثل سوء التغدية وبعض العوامل الكيميائية والأنفعالات الشديدة للأم و التى تؤثر على نمو الطفل منذ و لادته .

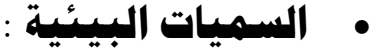

بستمر المخ فى إنتاج خلايا عصبية جديدة وشبكات عصبية وذلك لمــدة

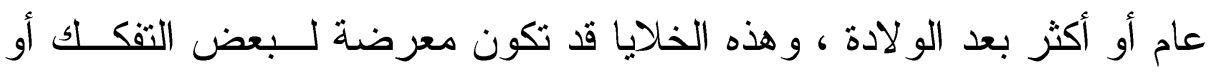
التمزف ، إن السميات البيئية من الممكن أن تؤدى إلى صعوبات التعلم بســبـ تأثنير ها الضار على نمو الخلايا العصبية مثل مادة الكانديوم و الرصاص وهما من المواد الملوثة للبيئة و الناتجة عن إحتراق البنزين والتى تؤدى إلى حدوث

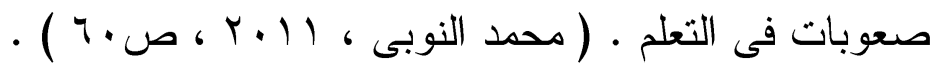




\section{• البيئة الدراسية :}

إن الصعوبات التعليمية قد تتنج بسبب خلل ما فى البيئة الدراسية ، قـــ ينجم عن عدم التو افق بين المواقف التعليمية وخصائص المتعلم ، وكذلك مــن خلال مستوى التوقعات التى يصر ح بها المدرسون لطلابهم ، ومقدرة المعلـــم على التعامل مع الحاجات الخاصة للطلاب داخل الصف ، وحساسية المعلــــ

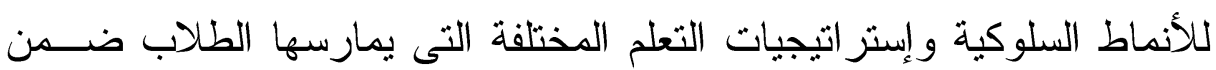
بيئة المدرسة ، كما أن بعض الأطفال ذوى الصعوبات التعلمية ، لايتخــذون

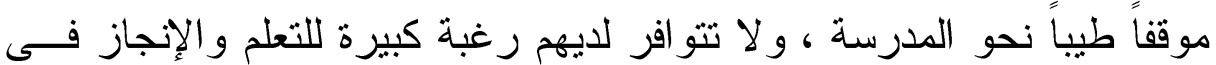
المجالأت الضرورية ، وقد تكون مشكلتهم دالة على الأنظمة القيمية لآبائهم ، و على نظرتهم التى تضع المهن الأكاديمية فى مكانه منخفضة .

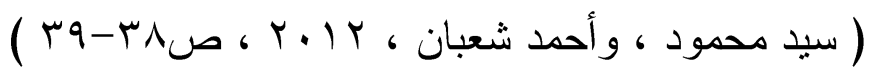

ويتفق ذلك مع ما أشار إليه (Sujathamalini,J,2007,p.18) أن على

المعلم أو المعلمة المعنين بالتعامل مع الأطفال ذو صعوبات التعلم أن يتمتعوا

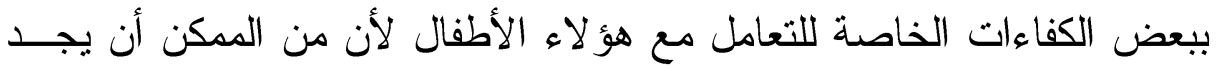

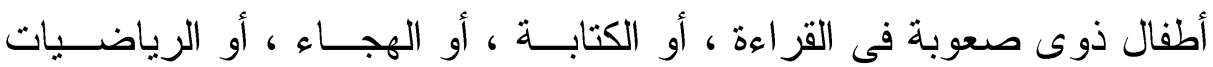
أوعدم القدرة على التتظيم ، و غالباً ما ينتهى المطاف بشكل عام بمثل هـــؤلاء

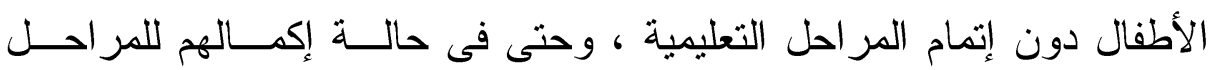
التعليمية يبقى تحصيلهم الدر اسى أقل مقارنه بمستوى الطلاب الذين ليس لديهر صعوبه تعلم ودر اسة (Collins,B,2004,pp. 360-361) التى تؤكـــد علــى دور المعلم بأن هناك بعض الأطفال الذين لا يتمتعون بالكفاءة الجسمية و الذهنية ولا

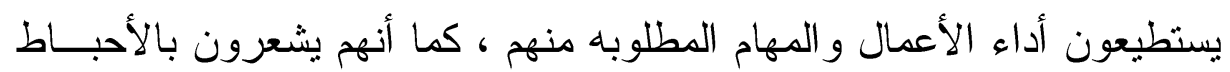
ولا يستطيعون تحقيق أهدافه ، ومن هنا لابد من أن يقوم المعلم بمســاعدتهر لكى ينمى من مستويات الطموح لايهم • 
Family and social environment البيئة الأسرية و الإجتمهاعية •

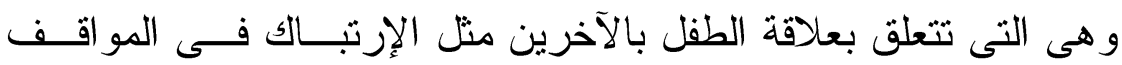

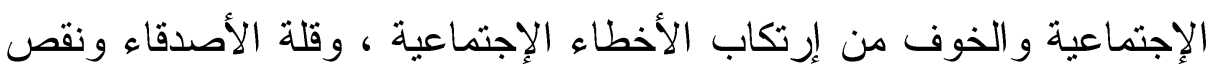

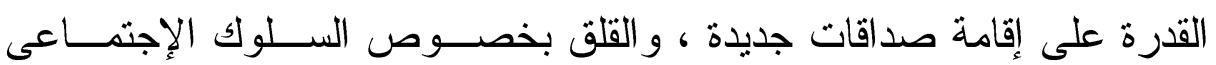

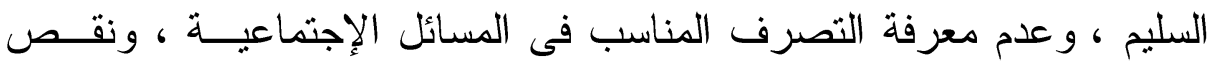

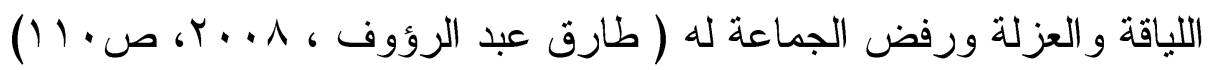

\section{• الإصابات البسدسية :}

إن بيئة الطفل غير اللائقة جسدياً لها تأثير كبيرفى حياة الطفل الأكاديمية ،

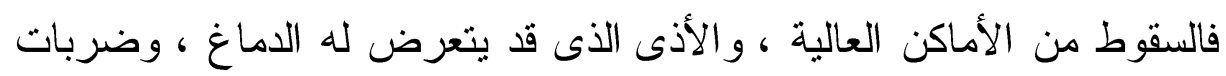

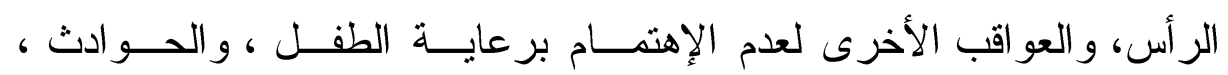

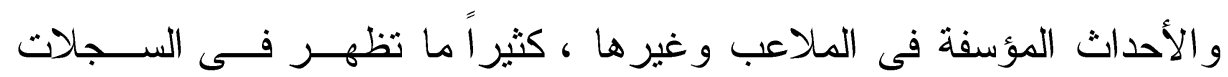
المرضية للأطفال الذين نم الكثف عنهم ، بأنهم يعانون من صعوبات تعليمية ، كما يمكن أن ترد بعض صعوبات التعلم إلى الأذى الجسدى الناجم عن إساءة

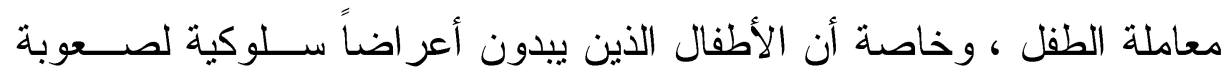

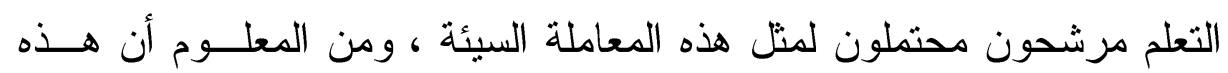
المعاملة السيئة قد تصدر عن شعور الو الدين بالخيبة لقاء المبالغة فى توقعاتهم للطفل ومايعلقون عليهم من آمال مستقبلية .

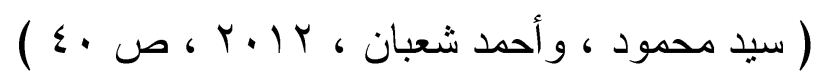

\section{تصنيفات صعوبات التعلم Learning disabilities rankings} أوضحت دراسة (Fietcher,J.,2012,pp.1-25) أن صعوبات الــتعلم هى عبارة عن إضطر اب فى المهار ات الأساسية التى يحتاجها الفرد وتقسم إلى صعوبات نمائية تتعلق بجوانب النمو وأخرى أكاديمية تتعلــق بــتعلم الكتابـــة

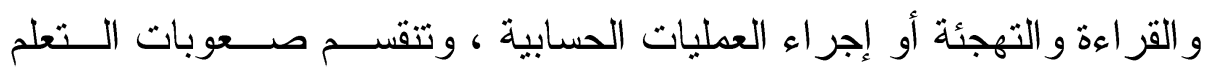


النمائية إلى قسمين :Primary Learning Disabilities فى العمليات العقلية وتشمل الانتباه ، الذاكرة ، الادر الك و الصعوبات الثانوية : SecondaryLearning Disabilities ومن خلال تُصنيفات صعوبات التعلم السابقة يتم تقسيمها إلــى ثــلاث

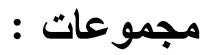

Developmental Learning Disabilities صعوبات التعلم النسمائية يقصد بصعوبات التعلم النمائية ، هؤلاء الأطفال الذين يظهرون تباعـــاً

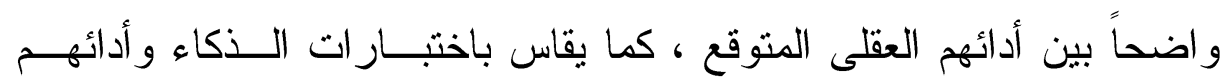
الفعلى ، كما يقاس بالإختبار ات التحصيلية فى مجال أو أكثر بأقر انهم فى نفس بأ العمر الزمنى ، و المستوى العقلى ، و الصف الدراسى ، ويستثنى من هـــؤلاء

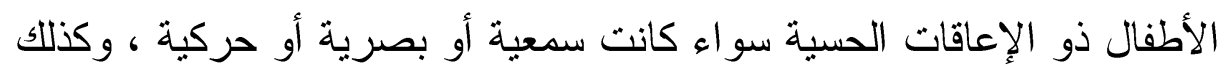
المتأخرين عقلياً و المضطربين إنفعالياً و المحرومين ثقافياً و إقتصادياً .

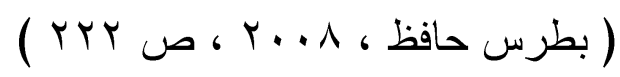

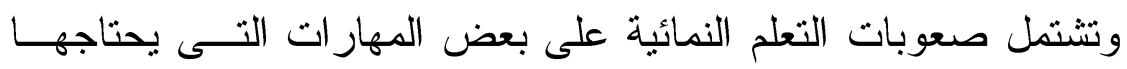
الطفل بهدف التحصيل فى المجموعات الأكاديمية ، فحتى يتعلم الطفل أســهـ

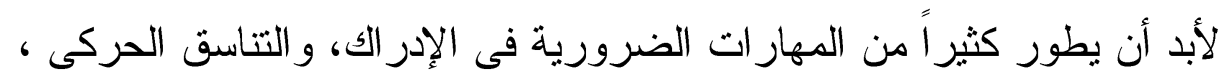

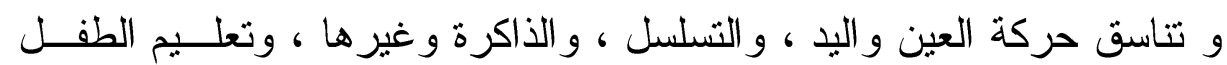

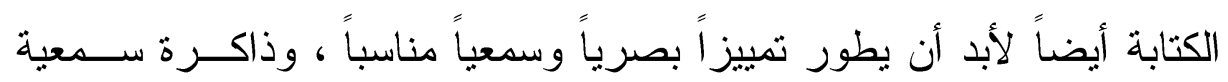
بصرية ، ولغة مناسبة وغير هامن العمليات ، ولحسن الحظ فإن هذه الوظائف

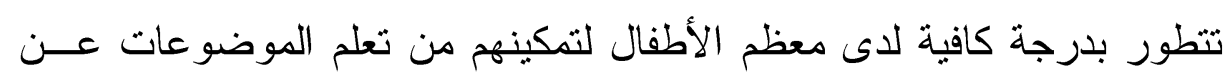
طريق تعويضها من خلال وظائف أخرى ، عندئذ تكون لايه صعوبة فى تعلم

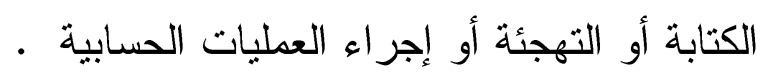

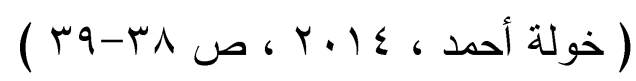


Wallace, G., \& McLoughlin, J., وقـــ أوضــح كــلا مــن (1979,pp.210-211) بأن الأطفال ذوى صـــوبات الـتـعلم فـى الإنتبـــاه لايستطيعون التركيز فى أى نشاط فردى لأكثر من عدة دقائق ويسهل تشتتهر بالمثيرات غير مناسبة التى لاتتعلق بموضوع النشاط ، فهم يواجهون صعوبة

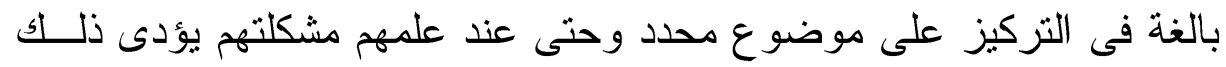

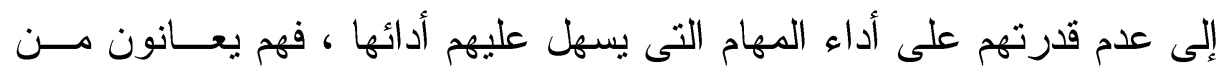
قابلية التشتت التى تعتبر بكونها مشكلة إجتماعية سلوكية ترتبط علـى نحسـو قريب بالتزكيز ، بجانب ضعف قدرتهم علــى عـزل المثيـــرات الخارجيــة و التركيز الأنتقائى على الفرض المهح ، بالإضافة إلى أنهم يو اجهون صعوبات بالغة فى التركيز المستمر على جميع الجوانب المتعلقة بالفروض الأكاديميــة

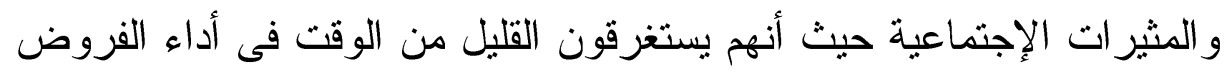
الهامه ، و الكثيرمن الوقت فى السلوك الغير مثمر على خلاف نظائرهم .

\section{Academic Learning Disabilities صعوبات التعلم الأكاديمية التية}

عندما نلاحظ إضطر ابات فى سير عملية التعلم عند الطفل فى الروضة ، فإن هذا يعطى لنا مؤشراً بأن لديه صعوبة فى التعلم ، فالطفل ذوى صعوبات التعلم النمائية يعانى من صعوبات التعلم الأكاديمية و التى تتمثل فـى قصى فــور المهار ات ما قبل الأكاديمية لديه .

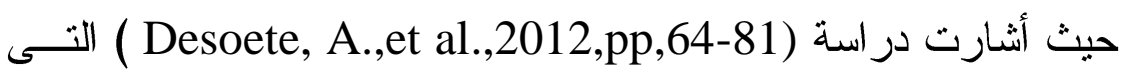
أجريت على ( ع 7 ) طفلاً وطفلة بمرحلة رياض الأطفال ، ممن يعانون مسن صعوبات التعلم ، و هدفت هذه الدراسة إلى رصد قدرة الأطفال على إجــراء عمليات التفكير خاصة الرياضـى منها ، و أداء العمليات العقليــة و الحســابية ،

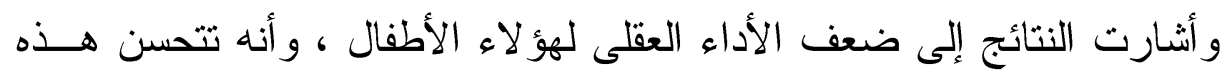
القدرة من خلال تتمية مهارة حل المشكلات لدى هؤلاء الأطفال . 


\section{صعوبات التعلم الإجتماعية والإنفعالية :}

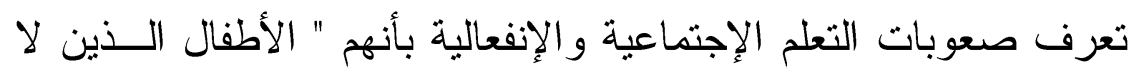

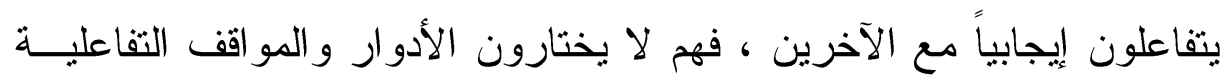

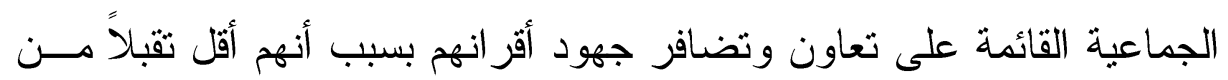
أقر انهم ومعلميهم ، وحتى عندما يحاولوا أن يبدأوا أو ينشى تُعَ تفاعلاً إجتماعياً

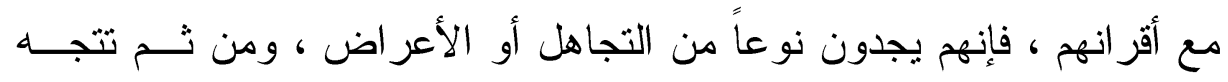
أنشطتهم وتفاعلاتهم وسلوكياتهم إلى أن تكون مضطربة أو عدو انية أو غيـر فئر

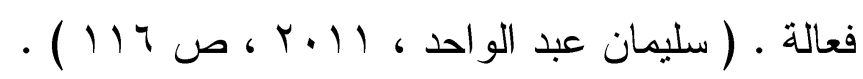

حيث أسفرت نتائج در اسة (Armstrong, J.,2002) عن أهمية تــوفير الإطار التعبيزى الإبداعى من خلال الدر اما للأطفال ذوى صعوبات التعلم للحد من صعوبة التو اصل الإجتماعى مع أقر انهم و إكتساب الثقة بالنفس و إحتــرام الذات و التعبير عنها و التعاون اليومى مع الآخرين . ودراسة (Comer, U. 2009) التى بعنو ان " إستخدام الدمى كممارسة تعليمية مع الأطفال ذوى صعوبات التعلم " ، و التى هدفت إلى إستخدام الدمى لعى إنى

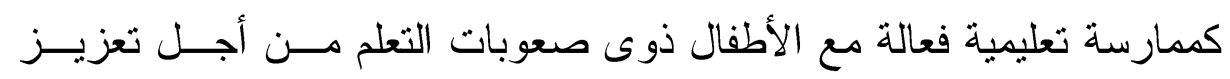
إندماجهم ومشاركتهم مع زملائهم العاديين بجانب رفــع مســتوى رفــاهيتهم

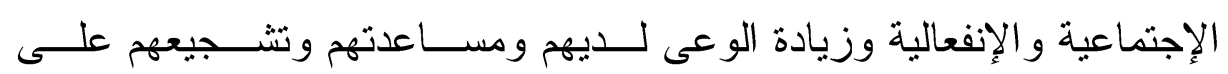

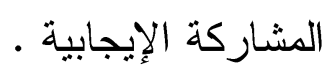

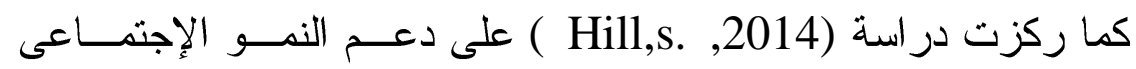
و الإنفعالى لدى الأطفال ذوى صعوبات التعلم من خلال الأنشطة الفنية لتنميـة

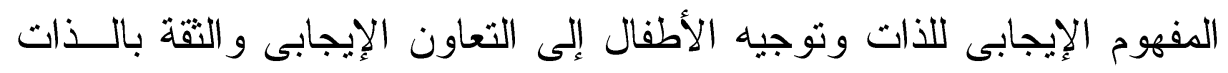
وتقليل التوتر النفسى لدى الأطفال ذوى صعوبات التعلم .

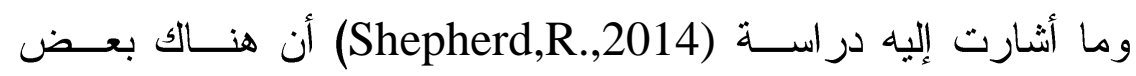

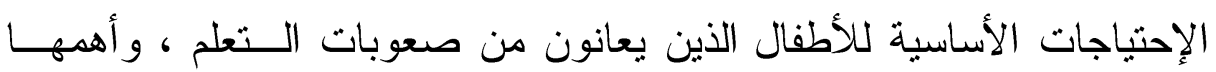




\section{فاعلية برناهمج تدريبى لتنسمية بعض خصائص التفكير الإيبابى}

لدى أطفال هما قبل المدرسة ذوى صعوبات التعام

الممارسة المبنية على المعرفة و المهار ات و الفهر ، فــإن المســـاعدة المبكــرة

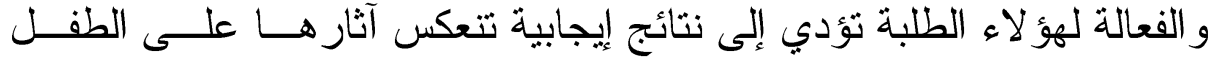
و علاقاته بالآخرين وتزيد من ثقتهم بأنفسهم وترفع من تقدير الذات لديهم .

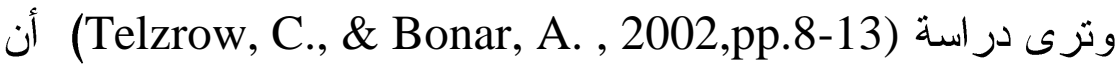
من الأساليب الملائمة لتحسين التعلم للأطفال ذوى صعوبات التعلم هو أسلوب حل المشكلات من خلال إكتســاب مهــار ات التكيــف النفســى و المهـــار ات الإجتماعية ، و أسلوب حل المشكلات ينمى من خلاله بعض مهار ات التفكيـر

الناقد و التأملى كما ينمى لديهج روح التعاون و العمل الجماعى و الإيجابية . كما أن هناك علاقة بين صعوبات التعلم النمائيــة وصـــعوبات الــتعلم الأكاديمية ، وصعوبات التعلم الإجتماعية و الإنفعالية فهى علاقـات تخضــع لنماذج سببية تقوم على التأثير و التأثر،حيث تشكل صعوبات الــتعلم النمائيــة المحددات الرئيسية لصعوبات التعلم الاكاديمية ، كمـــا أن صـــوبات الــتعلم الإجتماعية و الإنفعالية هى إفرازات لاســتمرار صـــوبات الــتعلم النمائيــة و الأكاديمية دون تدخل علاجى .

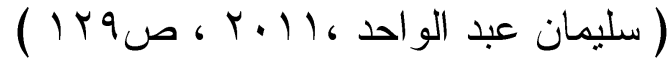

\section{خصائص الأطفال ذوى صعوبات التعلم :}

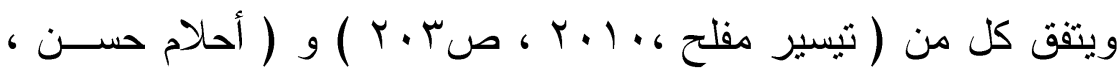

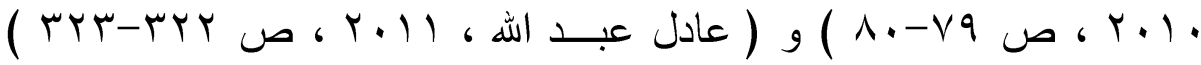

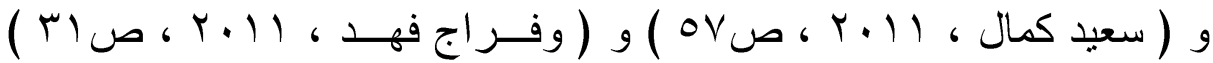
و ( Learner,J.,2000,p15 ) على أن أهم الخصائص الدالة على صعوبات

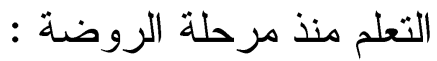
- مستوى ذكاء عادى أو عالى .

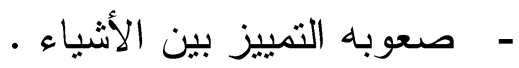


- مستوى تحصيل متدن لا يتفق مع مستوى الذكاء. . - عدم القدرة على إصدار الإستجابة المناسبة للمثير أو للموقف عامة . - قصور فى العمليات الخاصة بالتآزر و التتاسق . - نشاط مفرط لايتتاسب مع العمر الزمنى للطفل . - - القابلية للتشتت و الإندفاعية . - تبديل مو اضع الحروف و الأعداد فضلاً عن اضطر ابات النطق عامة . - مصور فى الدافعية . - قصور الأدر الك الحسى والأنتباه و الذاكرة . - إضطر اب التفكير أو قصوره . - عدم القدرة على حل المشكلات و التتظيم . - عدم القدرة على التركيز - مصور العمليات العقلية . - تأخر فى تكوين ونمو المفاهيم المختلفة.

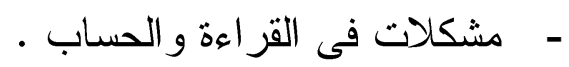
- عدم القدرة على التحكم فى الحفز ات المختلفة. - التأخر فى أكتساب اللغة و التخاطب. - - تأخر التناول السمعى للمثير ات. - وجود صعوبة فى التناول البصرى للمثير ات. - تأخر او قصور فى الذاكرة قصيرة وطويلة المدى. - وجود مشكلات انفعالية-اجتماعية عند الطفل. - وجود صعوبة في القيام بالمهار ات الحركية الكبيرة و الدقيقة.

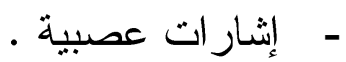

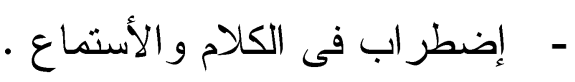


ويؤكد على ذلك (Sujathamalini,J,p.,2010,p.9) على أن الأطفال ذوى صعوبات التعلم يتسمون بفرط الحركة ، و الخلــلـل الإدر اكـى الحسـى ، و إختلالات عامة فى التتظـــم ، و الإندفاعبــة ، و إضــــربات فــى الــذاكرة و التقكير ، و إضطر اب الإنتباه ، ومهار ات القر اعة و الكتابة و النطق و العمليــات الحسابية ، و إضطر ابات فى التحدث و اللغه ، و الإضطر ابات عصبية . كما تهدف دراسة (Hamid,A.,2015) إلى معرفة المشاكل العاطف.ــة و السلوكية للأطفال ذوى صعوبات التعلم وذلك باستخدام المــنهج الوصــفى وتكونت عينة الدراسة من ( .0 ) طفلا ذوي صعوبات التعلم فـي المملكــة العربية السعودية و أشارت النتائج إلى بعض الخصائص الذى يتميز بها هؤلاء الأطفال وتتعلق بمشاكل التفكير ، وضعف التركيز ، وتشتت الإنتباه ، وقلـــة النشاط ، و عدم التفاعل ، و عدم الشعور بالثقة بالنفس ، و الحد من قيمة النفس ،

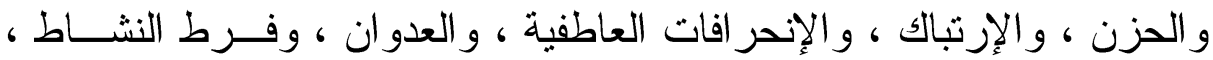
و الخوف ، و النوم لفترات قصيرة ، إستثر ار التغير ات في الجلوس ، و القلــق

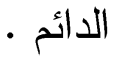

وما قامت بتفسيرة در اسة(Jenkins, L.,\& Indiana U., US,2014)

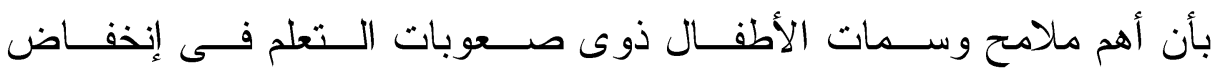
الأداء ودافعية الإنجازو الثقة بالنفس وتقدير الذات و إنخفاض الكفـــاءة الذاتبـــة الأكاديمبة . الأد ودية. وتتفق الباحثة مع كافة وجهات النظر التى تقــدمت حــول خصــائص الأطفال ذوى صعوبات التعلم ويمكن إجمالها فى تحديد بعض المظاهر العامة لهم وهى : إضطربات فى الإصغاء : تعتبر ظاهرة شرود الذهن ، و العجز عـن الإنتبــاه ، و الميل للتشتت نحو المثيرات الخارجية ، من أكثر الصفات البارزة لهــؤلاء 
الأفر اد ، إذ أنهخ لا يميزون بين المثير الرئيسى والثانوى ، حيث يمل الطفل

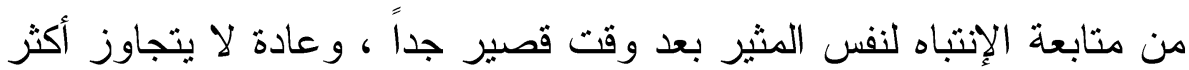

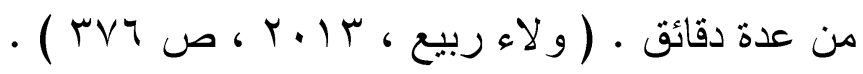
الحركة الرائدة : تميز بشكل عام الأطفال الذين يعانون من صعوبات مركبة من رهن

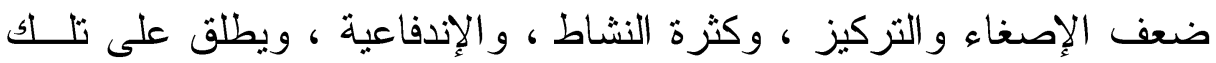
الظاهرة باضطربات الإصغاء و التركيز و الحركة الزائدة ( DHD ) .

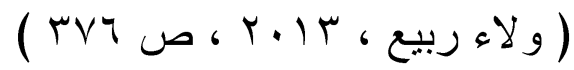

الإندفاعية والتهور : يتميز هؤ لاء الأطفال بالتســرع فـى إجابــاتهم ، وردود

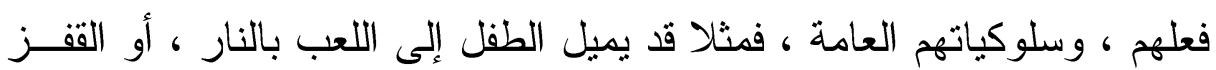
إلى الشارع دون التفكير فى العو اقب المترنبة على ذلك ، كما إن البعض منهر

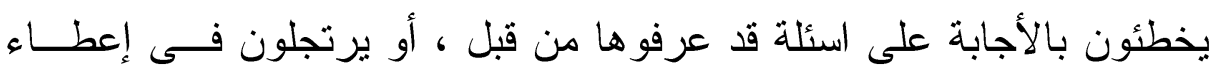

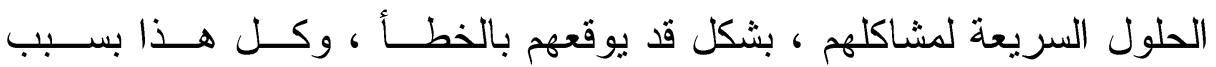

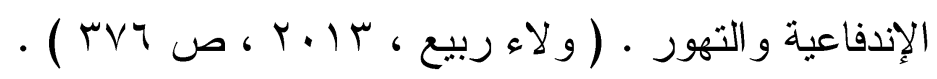

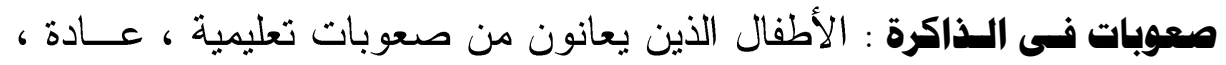
يفقدون القدرة على توظيف تلك الأقسام أو بعضها بالشكل المطلوب ، وبالتالى يفقدون الكثير من المعلومات ، مما يدفع المعلم إلى تكرار التعليمات و العمـلـل

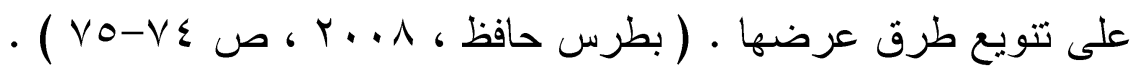

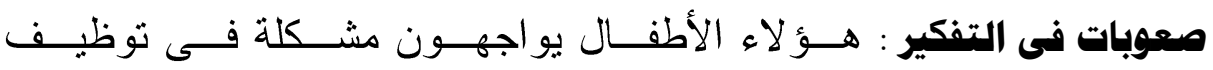
الإستر اتيجيات الملائمة لحل المشاكل التعلمية المختلفة ، فقد يقومون بتوظيف استر اتيجيات بدائية وضعيفة لحل مسائل الحساب وفهم المقروء ، وكذللك عند الحديث و التعبير الكتابى ، جزء كبير من ثلك الصعوبات يرجع إلـى افتقــار

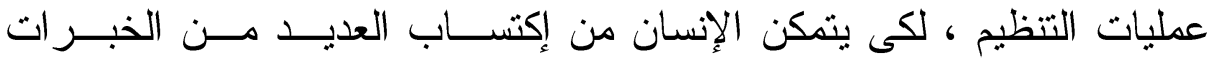
و التجارب ، فهو بحاجة إلى القبام بعملية تنظيم تلك الخبرات بطريقة ناجحة ،

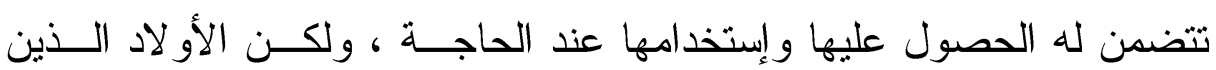




\section{فاعلية برنامج تدريبى لتنمية بعض خصائص التفكير الإيجابى}

لدى أطفال ها قبل المدرسة ذوى صعوبات التعلم

يعانون من الصعوبات التعليمية وفى المواقف يستصعبون بشكل ملحوظ فـى تللك المهمة ، يستغرقهم من الوقت للبدء بحل الواجبات و إخر اج الكراسات من الحقيبة ، و القيام بحل مسائل حسابية متو اصلة ، أو ترتيب جملهم أثناء الحديث

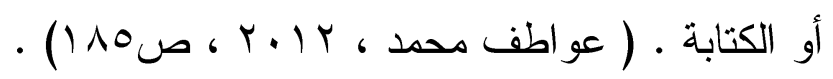

صعوبات فى فهـهم التعليمسات : التعليمات التى تعطى لفظيا ولمرة مــن قبــل المعلم تشكل عقبة أمام هؤلاء الأطفال ، بسبب مشاكل التركيز و الذاكرة ، لذلك نجدهم يسألون المعلم تكراراً عن المهمات أو الأسئلة التى يوجهها للطــلاب ، كما وأن البعض منهم لا يفهمون التعليمات المطلوبة منهم كتابياً ، لذا يلجــأون إلى سؤال المعلم أو تتفيذ التعليمات حسب فهمه الجزئى ، أو حتى التوقف عن التنفيذ حتى يتوجه اليهم المعلم ويرشدهم فردياً .

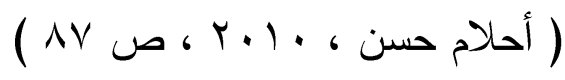

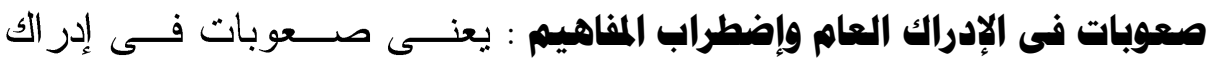
المفاهيم الأساسية مثل : الشكل و الأتجاهات و الزمـــان و المكـــان ، و المفــــاهيم المتجانسة و المتقاربة و الأشكال الهندسية الأساسية و أيام الأسبوع •

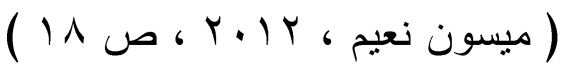

صعوبات فى التآزر الحسـى الهركى : عندما يبدأ الطفـلـل يرســـ الأحــرف أو الأشكال التى ير اها بالشكل المناسب أمامه ، ولكنه يفسر ها بشكل عكسى ، فإن ذلك يؤدى إلى كتابة غير صحيحة مثل كلمات معكوسة ، أو كتابة من اليسار لليمين أونقل أشكال بطريقة عكسية هذا التمرين أشبه بــالنظر إلــى المــر آة و وحاولة تقليد شكل أو القيام بنقل صورة تر اها العين بالثكل أو القيــام بنقـــلـ صورة تر اها العين بالثكل المقلوب ، فالعين توجه البد نحو الثئ الذى تـــراه بينما يأمر ها العقل بغير ذلك ويوجه اليد للإتجاه المغاير • 
صعوبات فى العضلات الدقيقـة : مسكة القلم تكون غير دقيقة وقد تكون ضعيفة أو أنهم لا يستطعون تتفيذ تمارين بسيطة تتطلب معالجة الأصابع •

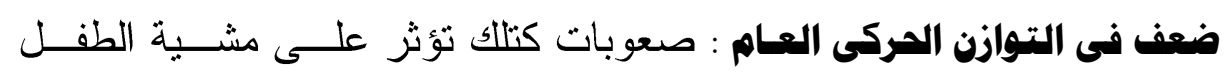

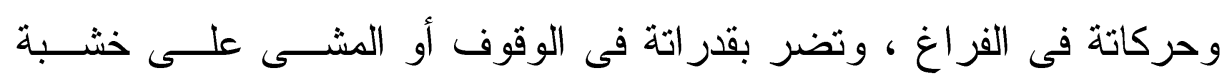

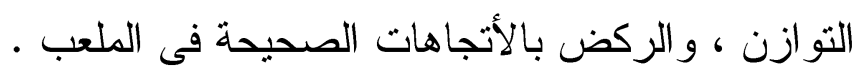
إضطربات عصبية هركبة : مشاكل متعلقة بأداء الجهاز العصبى المركزى ، و وقد تظهر بعض هذه الإضطربات فى اداء الحركات العضلية الدقيقة ، مثل الرسم و الكتابة .

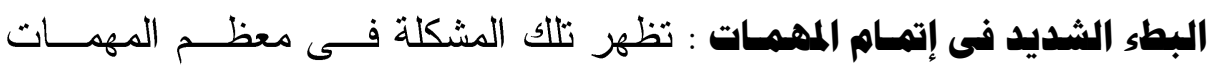

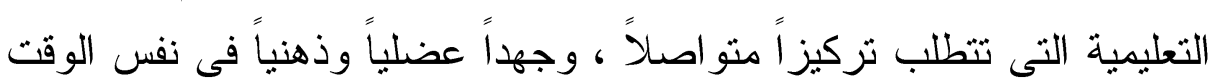
مثل الكتابة ، وتتفيذ الوجبات البيتية .

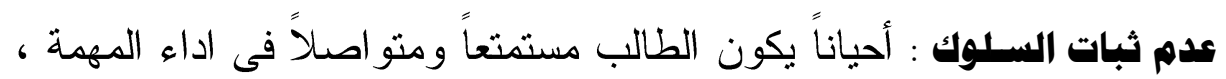
أو فى التجاوب و التفاعل مع الآخرين ، وأحياناً لا يستجيب للمتطلبات بــنفس ومن فئس الطريقة التى ظهر بها سلوكه سابقاً .

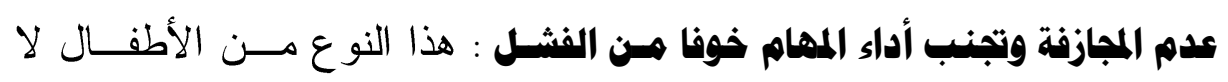
يجازف و لا يخاطر على أسئلة المفاجئة و الجديدة ، فهو يبغض المفاجـات و لا

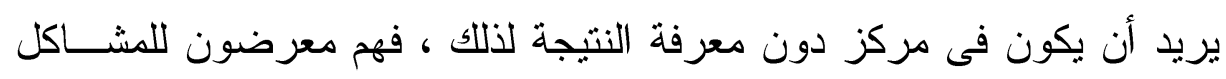

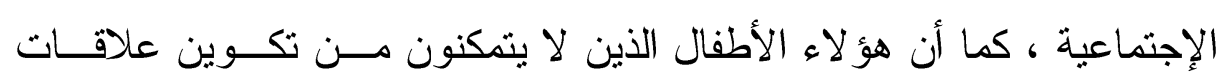
إجتماعية سليمة ، صنفو ا كنعزلين ، ومكتئبين ، وبعضهم يميلون الى لاءلى الأفكار

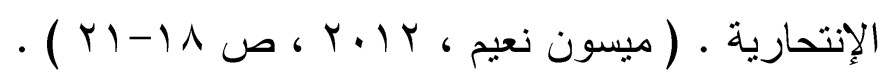

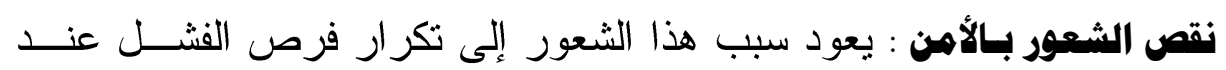
هؤ لاء الأفر اد ذوى صعوبات التعلم مما يدفع بهم الى التوتز والخوف من القيام

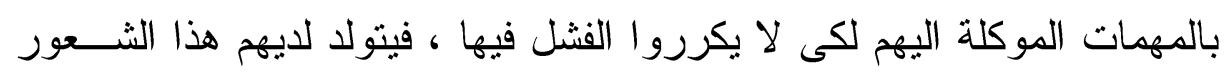

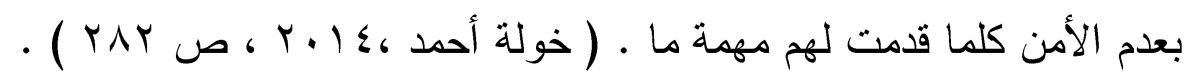




\section{فاعلية برناهج تدريبى لتنمية بعض خصائص التفكير الإيجابى}

لدى أطفال ها قبل المدرسة ذوى صعوبات التعلم

نقص الدافعية : يعانى الأفر اد ذوى صعوبات التعلم من ضعف فى الدافعيــة ،

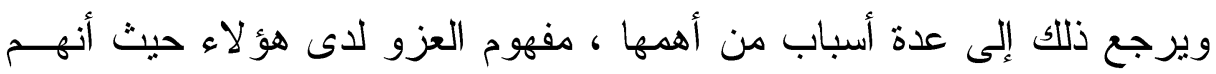
يعزون نجاحهم لعو امل خارجية كالحظ و الصدفة ، أما الفشل فيعزونه لقدر اتهم

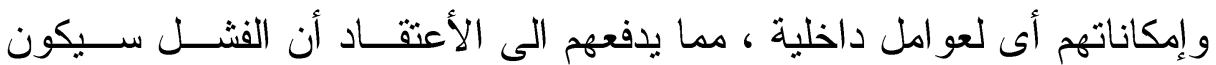

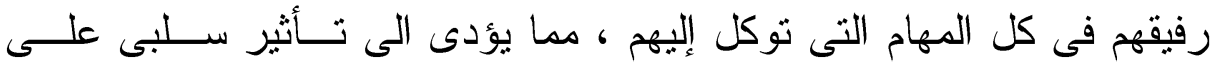

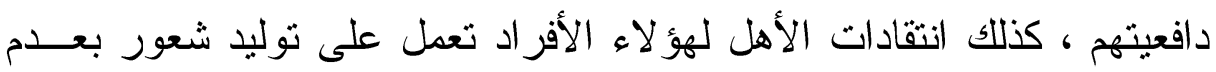
الثقة لديهم مما يؤدى لنقص الدافعية عندهم للقيام بمهامهح •

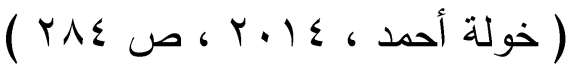

نقص فى القدرة على التعبير عن المشساعر : يعانى بعض الأطفال ذوى صعوبات التعلم من مشكلة فى التعبير عن المشاعر فى المواقف المناســبة ، وإختيــار الإنفعالات المناسبة لهذه المواقف ، ينتج هذا عن ندرة الإتصال ، و التفاعل بين هؤ لاء الأطفال ، و المحيط الإجتماعي من أجل ممارسة هذه الإنفعـالات فـى هـ

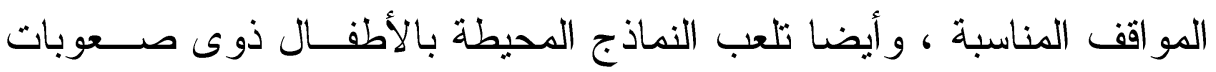

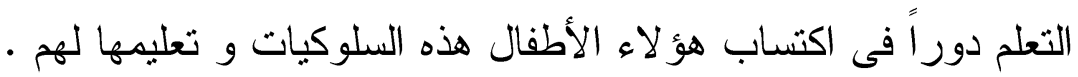

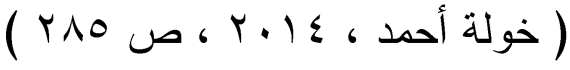

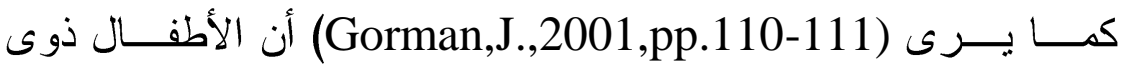
صعوبات التعلم يعانون من الإضطر ابات الإنفعالية وعدم القدرة على التكيـف و المرونه ، و أيضا وضعف إحتر ام الذات لديهز النى تكون بمثابة عاملاً مــن الإنـ

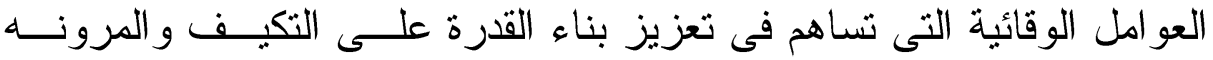
و الإيمان بالقدرة على حل المشكلات ، وحيث أن تلقى الــدعم مــن الأفــر اد البالغين حولهم الذين يلجؤن إليهم يسهح فى إكتساب التقة بأنفسهم و التوقعـات

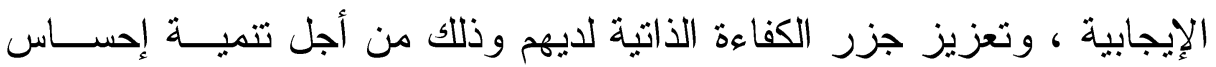
هؤ لاء الأطفال بالمشاعر الإيجابية والقدرة على التعبير عن مشاعرهم . 


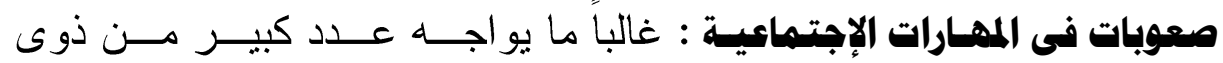
صعوبات التعلم صعوبات فى المهار ات الإجتماعية اللازمسـة للتعامسلـل مـــع الآخرين ، فقد تبين أن هؤلاء الأطفال يو اجهون مشكلات فى الحديث و التعرف

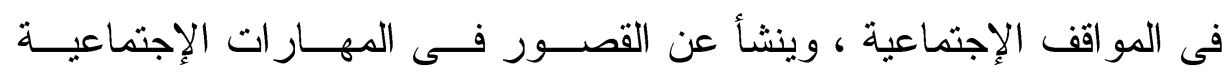

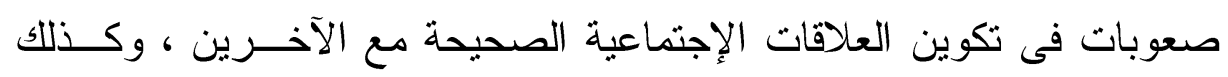

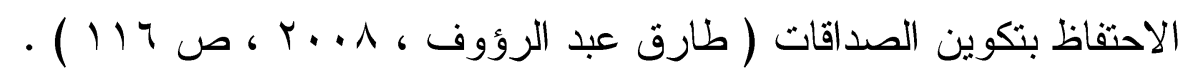
وذلك ما توضــحه در اســة (McMaster,M.,1995) و التــى أقــرت ضرورة تتمية المظاهر الإجتماعية وبعض مظاهر ومهار ات الحيــاة وكيفيـة

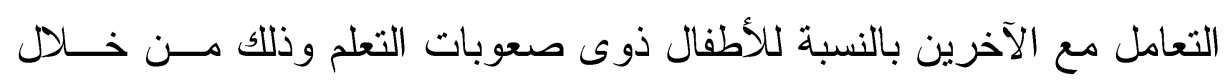
إكتساب مهار ات الإتصال الإجتماعية . وما اهتمت به در اسة (Montelpare, E., 2012 ) التــى بعنـــوان "

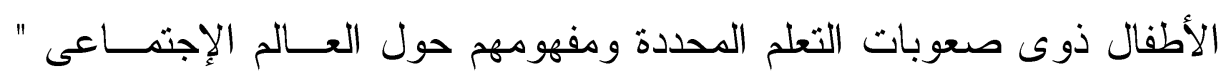
وتعتبر المهار ات الإجتماعية سلوكيات مكتسبة ، وأن الأطفال ذوى صعوبات التعلم لديهم صعوبة فى إظهار و اكتساب وفهم أهمية السلوكيات التـى تعتبـــر كمهار ات إجتماعية تمارس فى ضوء السياق الإجتماعى ، وتحدث عملية تتمية

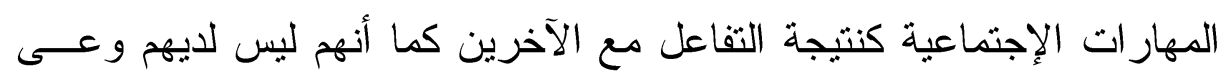
بماهو مقبول إجتماعياً فى وضـوء السياق التى تحدث فيه المواقف ورد فعل لإنل الآخرين المو مفيول

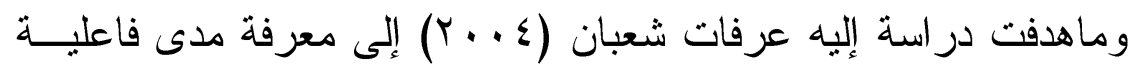

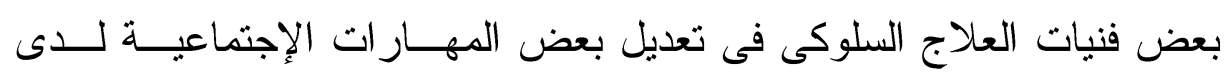
الأطفال ذوى صعوبات التعلم ، و الوقوف على أكثر الفنيات المستخدمة فاعلية

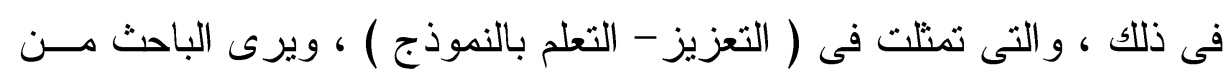
خلال در استه أن الدر اسات إختلفت حول تحديد أبعاد المهــار ات الإجتماعيــة

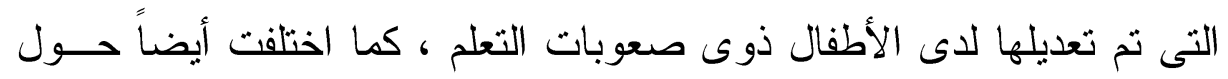




\section{فاعلية برناهج تدريبى لتنمية بعض خصائص التفكير الإيجابى}

لدى أطفال ها قبل المدرسة ذوى صعوبات التعلم

أساليب علاج المهار ات الإجتماعية ، فالبعض استخدم أسلوب التعزيز فقـ ط ، و البعض أستخدم أسلوب النمذجة و التدريب و الممارسة ، و آخرون اســتخدموا التعلم التعاونى ، وهذا ما يجعلنا فى حاجه لمعرفة أى من هذه الأساليب أكثـر كفاءة مع الأطفال ذوى صعوبات التعلم الذين يتسمون بسمات خاصة ، مثـــل تشتت الإنتباه ، النشاط الزائد ، الإندفاعية ، قله الإنتباه و غير ها و التى تجعل ما يصلح مع الأطفال العاديين من أساليب علاجية لايصلح معهر ، حيث يتم نمو وعى هؤلاء الأطفال بسرعة عندما يتعلق الأمر بما هو غير مقبول إجتماعيـاً

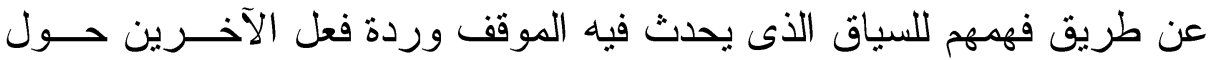

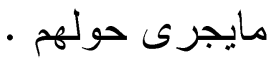

ضعف الثقـة بالـذات : ويشتمل مفهوم الثقة بالذات على مفاهيم ذاتية ســلبية أو متدنية ، حيث يحط الفرد هنا من قدر نفسه ، وينظر إلبها نظرة دونية ، كمـــا

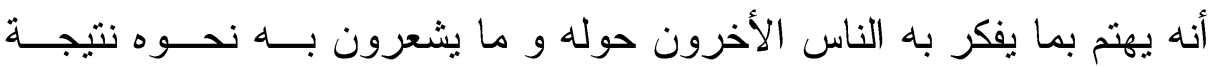
لافتقاده لتقته بنفسه ، وضعف الثقة بالذات يحدث نتيجة فشل الفرد فى المجال

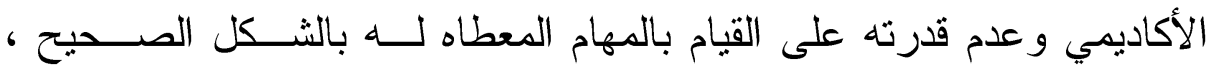
بالإضافة الى فشله فى المجال الإجتماعى وعدم قدرته على عمل علاقات مع الآخرين و جعل نفسه محبوباً لهم . كما دلت در اسة ( Talebizaadeh,S.,2009 ) إلى أن الأطفــال ذوى صعوبات التعلم يعانون من فقدان إحتر ام ذو اتهم و الثقة بأنفسهر ، كما يعـانون من الإكتئاب و الشعور بالنقص و لايوجد إختلاف تبعاً لمتغير الجنس وهذا مــــا أثبتته نتائج الار اسة من خلال تطبيق إختبار ات الإكتئاب و إحتر ام الذات . الإعتهاديسة : يمكن أن يعزى سلوك الإتكالية عند الأطفال ذوى صعوبات التعلم إلى عدم تطوير سلوك الإستقلالية لديهم من قبل الأهل منذ الصغر ، ويظهرون الإعتماد الز ائد على الأباء و المعلمين و إلى الحماية الزائدة لهم من قبل ذويهر ، 
بالإضـافة اللى شعور هم بعدم الكفاية الذاتية للقيام بالمهـــات الموكلــة الــــهم لوحدهم ، وهذا كله يؤدى بهؤلاء الأفر اد إلى تطوير شعور الإتكالية لديهم .

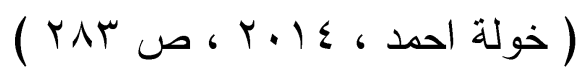

حيث وضــح (Wallace, G., \&McLoughlin, J.,1979,p.215) على أن هناك درجة من الإستقلالية لدى الأطفال فهم يصرون أنهم يستطيعون

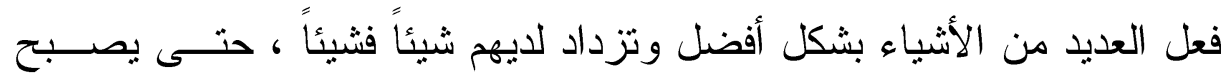

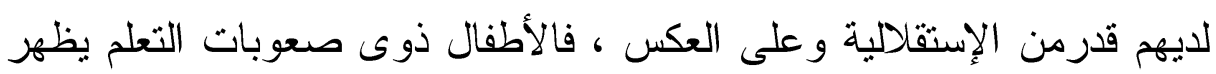
لديهم إتكالية مفرطة على أبائهم ومعلميهم ومن حولهم ، ويتطلب ذلك إتاحسـة

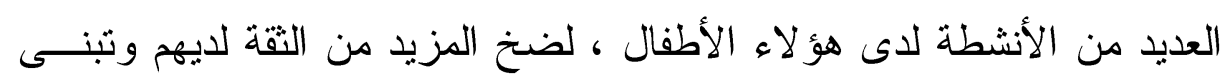

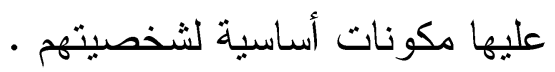
وترى دراسة (Gallegos,J.,2008) أن الأطفال ذوى صعوبات التعلم يعانون من الأحباط والقلق وحثت هذه الدراسة على نمو المهار ات الاستقلالية و الإعتماد على النفس لديهخ لمساعدتهم على تقليل هذه المشاعر السلبية ، كمــــا تهدف در اسة (McCay, L., \& Keyes, D.,2001,pp.70-78 ) تحسـين الكفاءة الذاتية للأطفال ذوى صعوبات التعلم من خلال تتمية بعض المهــار ات هـات

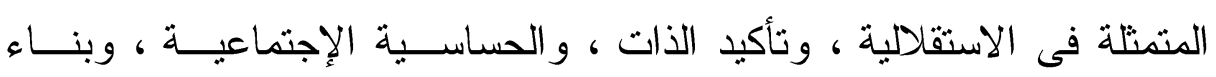
الصداقة ومهار ات حل المشكلات . الصنات

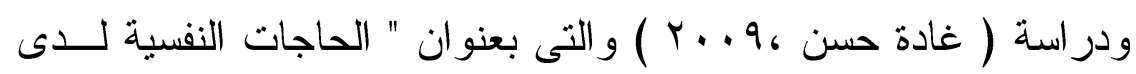

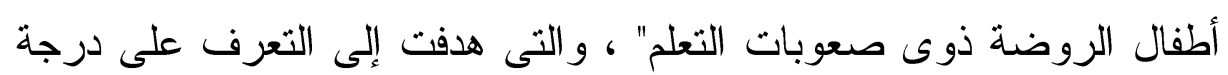
إثباع الحاجات النفسية للأطفال ذوى صعوبات التعلم ، و التعرف على الفروق

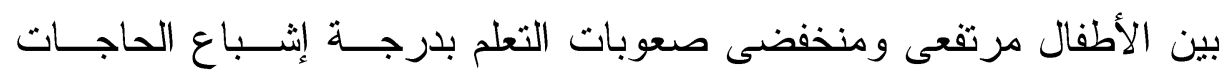

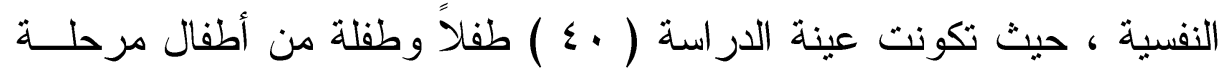
رياض الأطفال ، وقد إستخدمت الدراسة إختبار جودانف- هاريس ، وقائمــة

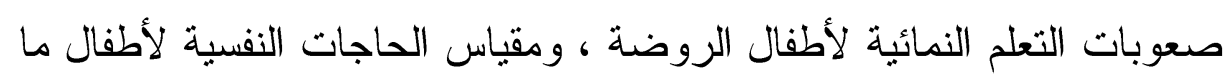


قبل المدرسة ، حيث أسفرت نتائج الدراسة عن عــدم وجــود فـروق بـين متوسطات رتب درجات الأطفال مرتفعى ومنخفضى صـــوبات الـتعلم فـى كى درجة إثباع الحاجات النفسية بالنسبة لجميع الأبعاد ( الإستقلالية - الكفاءة -

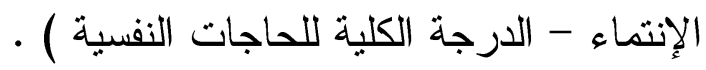

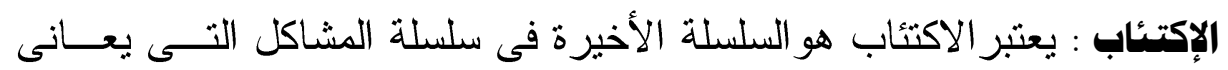
منها الافر اد ذوى صعوبات التعلم ، حيث أن شعور الاكتئاب يتولا نتيجة تر اكم

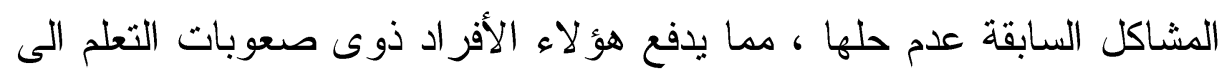

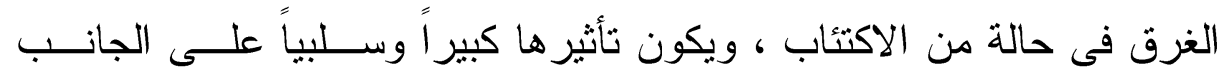

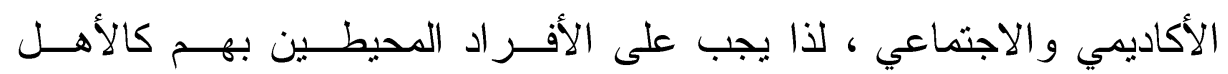

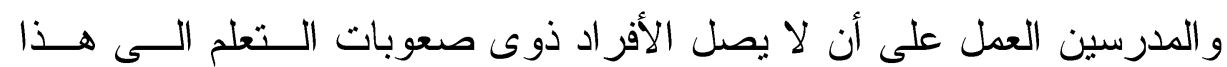

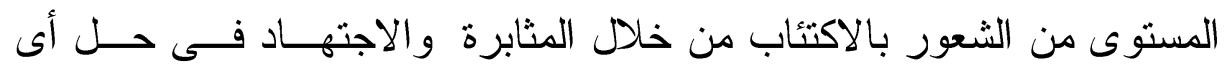

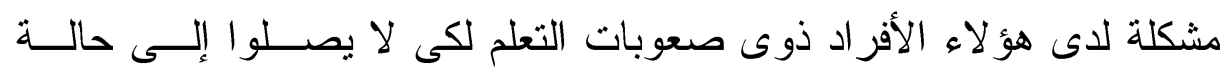

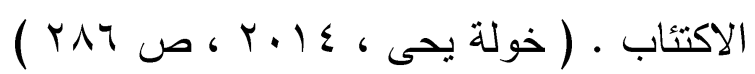

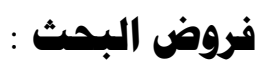
من خلال الإطلاع على الإطار النظرى ونتائج الدر اسات السابقة يمكـن

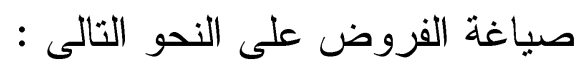
() لا يوجد فرق دال إحصائياً بين منوسطات رثب درجات أطفال المجموعة

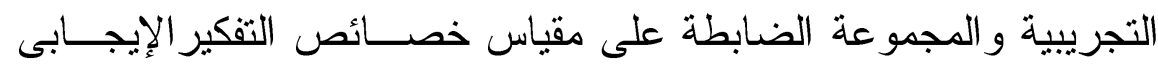

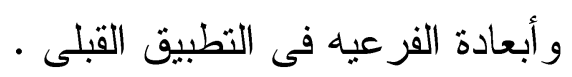
r) توجد فروق ذات دلالة إحصائية بين متوسطات رتــب درجــات أطفــال

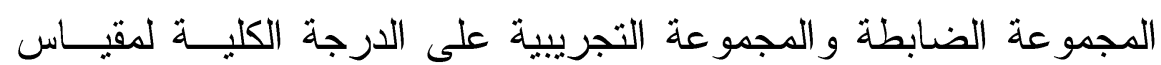
خصائص التفكير الإيجابى و أبعادة الفرعية ( بعد تطبيق البرنامج ) فـى التطبيق البعدى لصالح المجموعة التجريبية . 
r) توجد فروق ذات دلالة إحصائية بين متوسطات رتــب درجــات أطفــال المجموعة التجريبية فى التطبيق القبلى والتطبيق البعـدى علــى مقيــاس خصائص التفكير الإيجابى و أبعادة الفرعية لصالح التطبيق البعدى . ع) لاتوجد فروق ذات دلالة إحصائية بين متوسطات رتب درجـات اطفــال المجموعة التجريبية فى القياس البعدى والتتبعى بعد تطبيــق البرنــامج " شهر " على مقياس خصائص التفكير الإيجابى و أبعادة الفرعية .

الإجراءات المنهمية للبحث :

$$
\text { تتلخص خطو ات البحث الحالى فيما يلى : }
$$

تهديد خصائص التفكير الإيجابى التى يمكن تنميتها لدى الأطفـال ذوى صـعوبات

التعلم وذلك هن خلال :

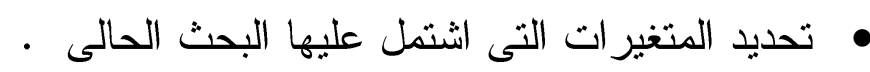
• الإطلاع على البحوث و الدراسات السابقة من ذات الصلة بموضوع البحث من البرامج التى تتاولت التفكير الإيجابى وبعض البرامج المقدمة للأطفال

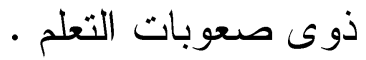

• استطلاع أر اء المعلمات عن الأطفال ذوى صعوبات الــتعلم لتحديدعينــة البحث .

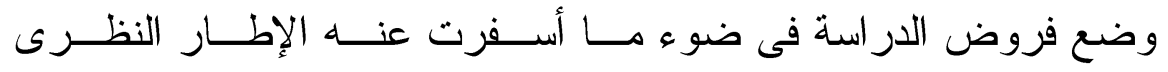
و الدر اسات السابقة . • إجر اء دراسة إستطلاعية من قبل الباحثة لاختيار عينة البحث من أطفــال

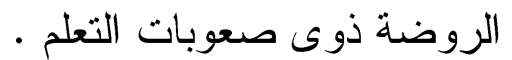

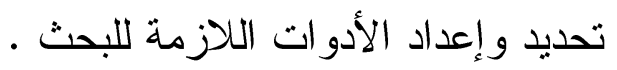

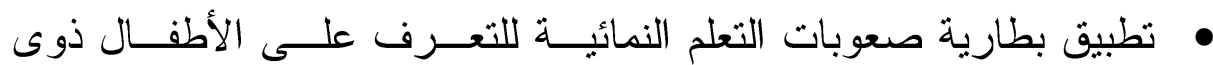

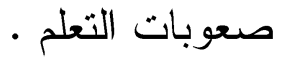
• إجر اء القياس القبلى و البعدى لمقياس خصائص التفكير الإيجابى • 


\section{فاعلية برناهج تدريبى لتنمية بعض خصائص التفكير الإيجابى}

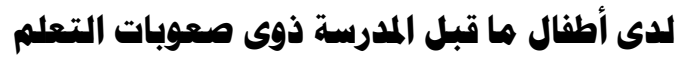

• إعداد إستمارة مستوى إقتصادى و إجتماعى للأطفال ذوى صعوبات التعلم

تفريغ وتسجيل البيانات لعمل المعالجات الإحصائية .

تفسير النتائج ومناقشتها فى ضوء الإطار النظرى و الدر اسات السابقة . تقديم مجمو عة من التوصيات و البحوث المقترحة في ضوء ما أسفر عنــــ • (البحث من نتائج

\section{منهفج البمث :}

يستخدم البحث الحالى المنهج التجريبـى لاختبـــار صـــة الفـروض الإحصائية الخاصة بالبحث الحالى باستخدام المجموعتين المتساويتين الضابطة و التجريبية ، وذللك لدر اسة أثز البرنامج ، وما تستخدمة الباحثة مــن وســائل و أدو ات لتحقيق الرنامج التدريبى ، القائم على تتمية بعض خصائص التفكيـر الإيجابى لدى أطفال ما قبل المدرسة ذوى صـــوبات الــتعلم لــدى أطفــال المجموعة التجريبية ، ومقارنة نتائجهم مع أطفال المجموعة الضابطة التى لا تتعرض للمتغير المستقل و عدم تعرضهم لتطبيق أنشطة البرنامج .

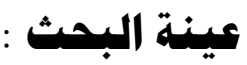

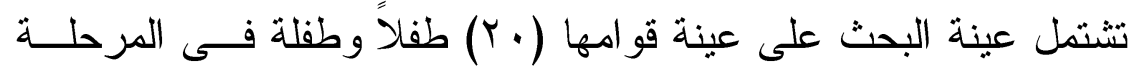
العمرية من ( 0-7 ) سنوات من أطفال المستوى الثانى فى الروضة (Kg2) ويتم تقسيمه إلى عينتين (• () أطفال من المجموعــة الضــابطة و ( · (1) أطفال من المجموعة التجريبية من روضة عمـر بــن الخطــاب التجريبيــة

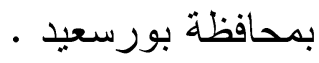

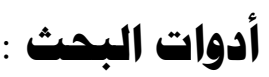

() إختبار رسم الرجل لجودانف هاريس ، تعريب فاطمة حنفى (r/9 ()) . r) إستمارة المستوى الإجتماعى و الأقتصادى (محمد بيومى ، (991) r) بطارية صعوبات التعلم النمائية ( سهير كامل ، بطرس حافظ ، ، 1 . ب ) 
ع) مقياس خصائص التفكير الإيجابى لطفل الروضة ( إعداد / الباحثة ) 0) برنامج التذريبى لتنمية خصائص التفكير الإيجابى ( إعداد / الباحثة ) 1) اختبار راسم الرجل لقياس ذكاء الأطفال"لجودانف-هاريس"

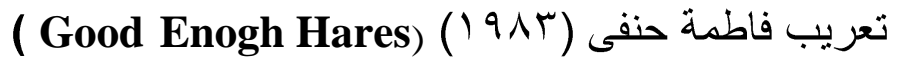

\section{وصف الإختبار :}

يتم إعطاء قلم رصاص وورقة بيضاء لكل طفل ، ويطلب منــهـ رســم صورة لرجل على أفضل نحو يستطيعه ، ويكون التقدير فيه على أساس دقــة الطفل فى رسم التفاصيل وليس على أساس المهارة الفنية فى الرســم ، ويــتم تصحيح الإختبار وفقا لمفردات التصحيح ، بحيث يعطى درجة على كل مفردة

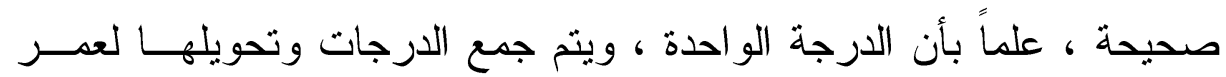

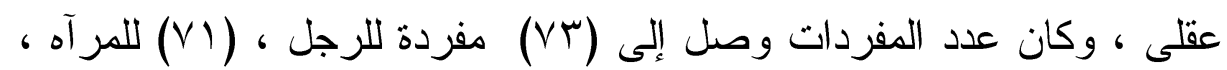
ويصلح هذا الإختبار لقياس ذكاء الأطفال من (س-س () سنه ، ولقد تم تطبيـق هذا الإختبار نظر أ لأنه من الأختبار ات الغير لفظية ، مما يجعلة مناسب لســن عينة البحث ، وقد إستتخدم بهدف التأكد من ان الأطفال ذوى صعوبات الـتـعلم لايعاغنون من إنخفاض الأكاء .

\section{التأكد هن تجانس العينة :}

جدول (1) الفرق بين رتب درجات أطفال المجموعة الضابطة ورتب درجات أطفال المجموعة التجريبية على اختبار رسم الرجل

( مستوى الأكاء ) فى التطبيق القبلى باستخدام قانون مانويتنى رلئ الرجل

\begin{tabular}{|c|c|c|c|c|c|}
\hline \multicolumn{2}{|c|}{ ت الجدولية } & \multirow{2}{*}{ ت المحسوبة } & \multirow{2}{*}{ مجموع الرتب مج (ب) } & \multirow{2}{*}{ ن } & \multirow{2}{*}{ المجموعـــة } \\
\hline عند مستوى I +, , & عند مستوى ه .,. & & & & \\
\hline \multirow{2}{*}{ $\uparrow, q \wedge \varepsilon$} & \multirow{2}{*}{$r \varepsilon, q 1 r$} & \multirow{2}{*}{ r..० } & $\Lambda \vee, \bullet$ & 1. & الضابطة \\
\hline & & & Irr,o & 1. & التجريبية \\
\hline
\end{tabular}


يتضح من جدول (1) أن قيمة ت ( المحسوبة ) و التى تساوى ( Y Y,0 )

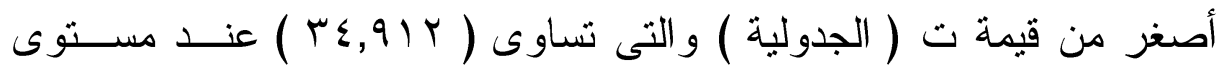

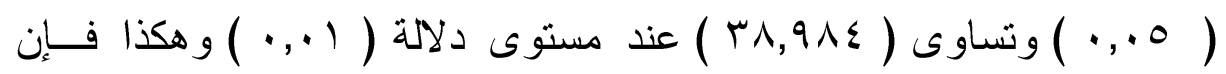

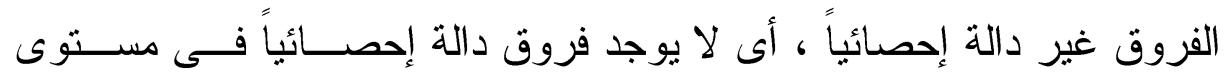

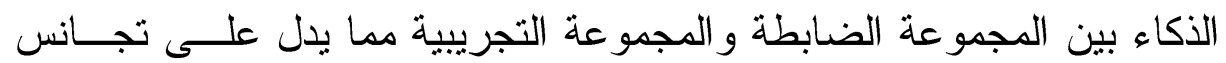

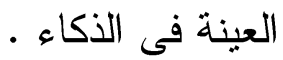

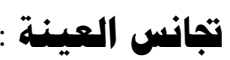
• عدم وجود فروق ذات دلالة إحصائية بين متوسطات رتب درجات كل من

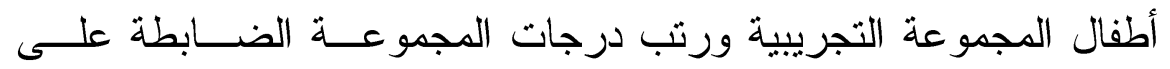
بطارية صعوبات التعلم النمائية لصالح التطبيق القبلى . r) إستـهارة المستوى الأقتصادى والإجتهماعى

\section{( كمال الدسوقى ، همهد بيوهى )}

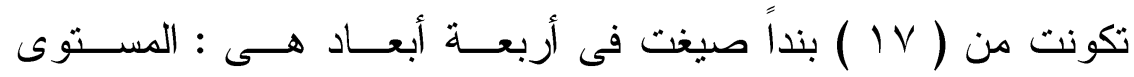
الإجتماعى ، ومستوى المعيشه ، و المستوى المهنى للـزـوجين ، و المســتوى

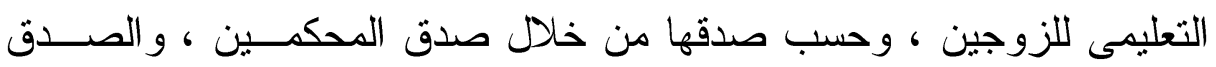
الذاتى الذى بلغ حوال ( وصل معامل الإزتباط بين التطبيقين ( 9 و, • ) .

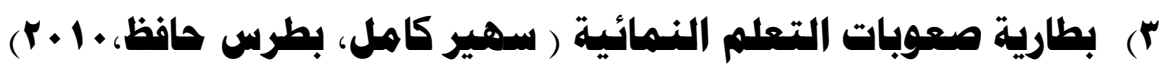
وصف البطارية :

تحدد البطارية أربعة عمليات معرفية أساســية ( الإنتبـــاه - المعالجــة

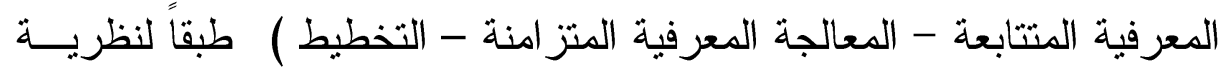
، تتاول ( 10 ) اختبار فرعى تم تصميمها فى صورة خريطة ذهنية PASS 
بهدف تشخيص جو انب القوة وجو انب الضعف لدى الأطفال الذي يعانون مــن صعوبات التعلم فى المرحلة العمرية ( ع-7 ) سنوات . . همتوى البطارية :

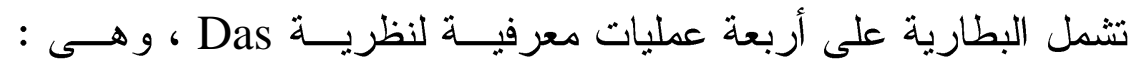

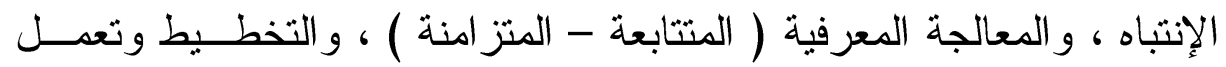
معتمدة على مايسميه Das بالأساس المعرفى ، و هذا الأساس المعرفى يبنـى لاى الطفل من خلال التعليم الرسمى ، و غير الرســى بــالمرور بــالخبرة ، فيساعده على حل المهام المدرسية و عندما يو اجه الطفل صعوبة فى إحدى هذه كئ

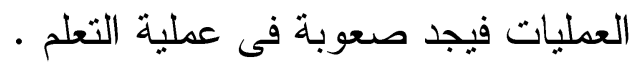
جدول ( r ) لا توجد فروق ذات دلالة إحصائية بين متوسطات رتب درجات كات كل من أطفال

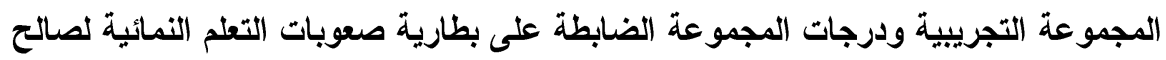
التطبيق القبلى .

\begin{tabular}{|c|c|c|c|c|c|c|c|c|c|c|}
\hline \multirow{2}{*}{ الالالة } & \multirow{2}{*}{ الدلاية } & \multirow{3}{*}{$\begin{array}{l}\text { :9: } \\
\text { N" } \\
\text { N }\end{array}$} & \multirow{3}{*}{ 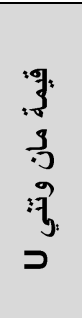 } & \multicolumn{6}{|c|}{ المجموعة } & \multirow[t]{3}{*}{ العينة } \\
\hline & & & & \multicolumn{3}{|c|}{ التجريبية } & \multicolumn{3}{|c|}{ الضابطة } & \\
\hline$\cdots 1$ & $\ldots 0$ & & & $\begin{array}{l}3 . \\
3 \\
\frac{3}{3} \\
\overline{3} .\end{array}$ & $\begin{array}{l}3 \\
3 \\
\frac{3}{3} \\
3 .\end{array}$ & $\overline{7}$ & $\begin{array}{l}3 . \\
3 \\
\frac{3}{3} \\
\overline{3} .\end{array}$ & $\begin{array}{l}3 \\
\frac{3}{3} \\
\overline{3} \\
3 .\end{array}$ & 兩 & \\
\hline$v_{1}$ & Ar & $17 . .7$ & 00,0 & $11 \cdot, 0$ & 11,0 & 1. & 99,0 & 9,90 & 1. & صعوبات \\
\hline
\end{tabular}

يتضح من جدول (Y) ويتضح من الجدول السابق أن ( ت ) الجدوليــة أكبر من المحسوبة ويترتب على ذلك عدم وجود فروق ذات دلالة إحصــائية بين متوسطات رتب درجات كل من أطفال المجموعة التجريبيـة ودرجــات المجموعة الضابطة على على بطارية صعوبات التعلم النمائية لصالح التطبيق · القبلى 
فاعلية برناهج تدريبى لتنهية بعض خصائص التفكير الإيجابى

لدى أطفال ها قبل المدرسة ذوى صعوبات التعلم

ع) هقياس خصائص التفكير الإيجابى لطفل الروضة ( إعداد / الباحثة ) الهدف هـن الميساس : قياس بعض خصائص التفكير الإيجــابى لــدى أطفــال الروضة ذوى صعوبات التعلم .

أهداف المقياس :

يهدف إلى تتمية بعض خصائص التفكير الإيجابى لأطفال الروضة ذوى

صعوبات التعلم ومن أهم هذه الخصائص التى تم تحديدها من قبل الباحثة :

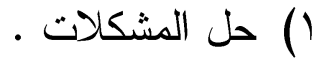

r r r r r الثقة بالنفس

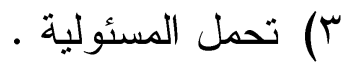

تطبيق المقياس :

يطبق مقياس التفكير الإيجابى للتعرف على المؤشرات السلوكية الإيجابية

لاى أطفال الروضة من ( ع-7 ) سنوات لذوى صعوبات التعلم فى التفكيـر

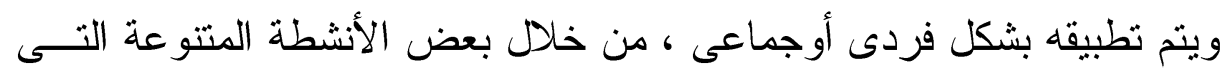
تتمى بعض خصائص التفكير الإيجابى مثل ( حل المشكلات ، الثقة بـالنفس ، تحمل المسئولية ) ، وملاحظة الأطفال وسلوكياتهم مــن حبــث الإيجابيــة أو أو السلبية من خلال عبار ات المقياس وتسجيل إستجابات الأطفال .

طريقة تصحيح المقياس :

يتكون المقياس من ثلاثثة خصائص للتفكير الإيجابى حيث يشـتمل كـلـل

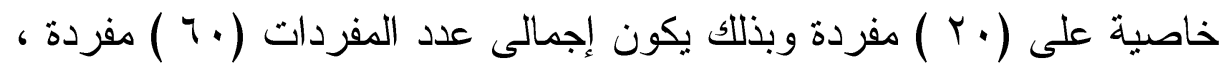

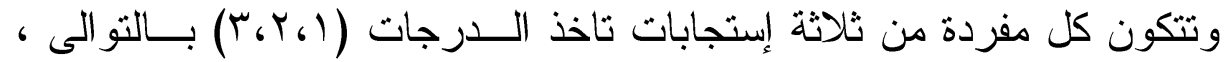
بحيث تمثل (r) الدرجة العظمى و الدرجة (Y) الدرجة المتوسطة والدرجة (1)

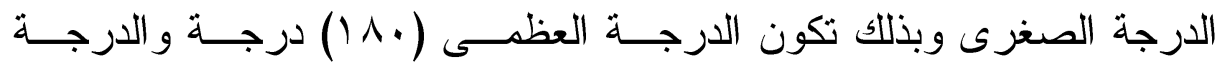

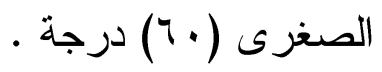




\section{زهن تطبيق المقياس :}

في ضوء تطبيق الباحثة للمقياس تم تحديد مدة زمنية لكل خاصية مسن

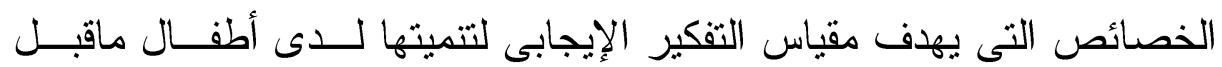

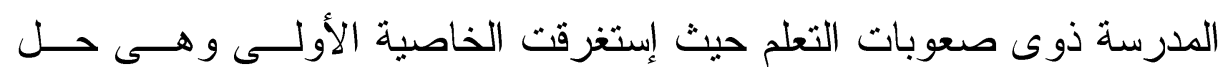

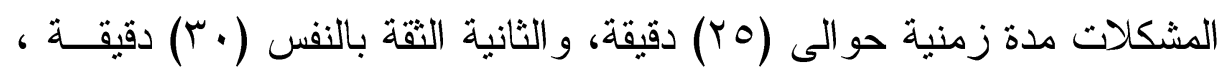
و الثالثة (·r) دقيقة ليصبح فى النهاية الزمن الكلى للنطبيق (م0) دقيقة . تعليمات الاقياس : وضع علامة ( ل ) للأستجابات الأتية (دائما - أحيانا- نادر ا ) المناسبة لمظاهر تفكير الطفل أمام كل عبارة .

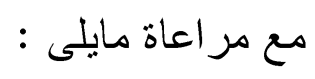
- قر اعة العبار ات بشكل دقيق قبل وضع العلامة . • ل لا يتم وضع أكثر من علامة أمام العبار ات .

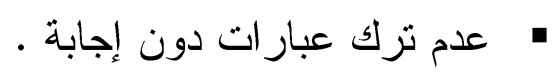

\section{تعليـهات التصحيح :}

يتم إعطاء الطفل ثلاث درجات إذا كانت الإجابة ( دائماً ) ودرجتين إذا

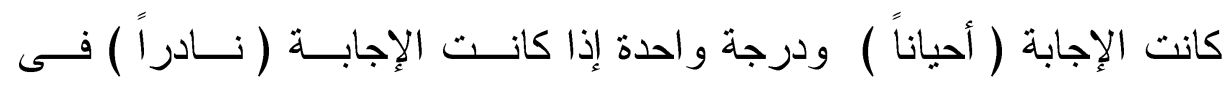

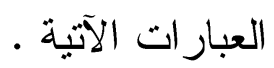

\section{الفصائص السيكوهنرية للمقياس :}

\section{التصقق هن الذصائص السيكوهترية للمقياس:}

تم تطبيق المقياس على (.0) طفل وطفلة فى مرحلة الروضة بمحافظة بورسعيد و هذه العينة ضمن العينة الاستطلاعية ، حيث تــم اســتبعاد نتــائج الأطفال الذين لم يستكملو الإجابة على المقياس أو الذين أظهروا عدم اهتمــام

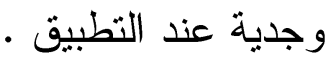




\section{فاعلية برنامج تدريبى لتنمية بعض خصائص التفكير الإيجابى}

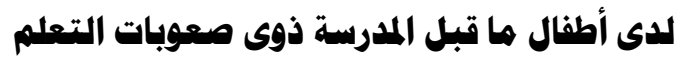

الثبات الكلى للمقياس : (ب)

() نم حساب ثبات الأبعاد و المقياس ككل بطريقة معامل ألفا كرونبـــاخ لــدى العينة الكلية ( ن = .0 ) طفل وطفلة بعد حذف المفردات غير الثابتــة ، حيث يمثل معامل ألفا متوسط المعاملات الناتجة عــن تجزئــة الاختبــار إلي أجز اء بطريقة مختلفة ، وبذلك فإنه يمثل معامل الارتبــاط بـين أبي جزئين من أجزاء الاختبار ، وتتضح نتائج هذا التحليل من الجدول التالي

$$
\text { رقم (r) }
$$

جدول ( r ) معامل ثبات ألفا كرونباخ للأبعاد و المقياس ككل

\begin{tabular}{|c|c|}
\hline معامل ألفا & البعد \\
\hline $.9 r \varepsilon$ & حل المشكلات \\
\hline. .910 & الثقة بالنفس \\
\hline $.9 r \varepsilon$ & تحمل المسئولية \\
\hline $.9 V$. & الارجة الكلية للمقياس \\
\hline
\end{tabular}

ويتضح من الجدول السابق رقم ( r ) ثبات المقبــاس كـــل والأبعــاد الفرعية الثناثة المتمثلة في : حل المشكلات ، التقة بالنفس ، تحمل المسـئولية لدى أفر اد عينة الدر اسة الحالية . r كما تم حساب معامل الثبات الكلي بطريقة التجزئــة النصــفية باســتخدام معادلتي سبيرمان / براون ، وجتمان بعد حذف المفردات غير الثابتــة ،

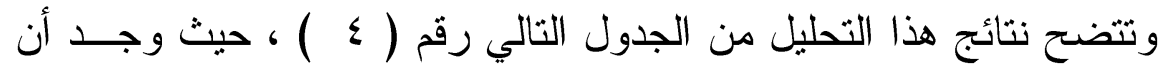
معامل الثبات الكلي للمقياس يساوى ( ب 9 9, · ) بطريقة سبيرمان / براون ويساوى ( • ؟ 9, ·) بطريقة جتمان ، وهو معامل ثبات مرتفع مما يدل على الثبات الكلي لمقياس خصائص التفكير الإيجابى • 
جدول ( ؛ ) ثبات مقياس خصائص التفكير الإيجابى بطريقة التجزئة النصفية

\begin{tabular}{|c|c|}
\hline عدد أفر اد العينة = . • & عدد المفردات = . 7 \\
\hline 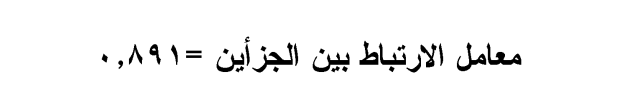 & م ( في حادلة الثبات بطريقة سبيرمان / براون \\
\hline معامل ثبات التجزئة النصفية بطريقة جتمان =. ؟ 9, . & ( في حاملة الثبات بطريقة سبيرمان / بروان \\
\hline مفردة في الجزء الثاني & مفردة في الجزء الأول \\
\hline معامل ألفا في الجز \& الثاني = ه ؟ 9 , . & معامل ألفا في الجزء الأول = r 9 ه, . \\
\hline
\end{tabular}

ويتضح من خلال ما سبق الثبات الكلي للمقيــاس وكـــللك الخصـــائص الثلاثة المكونة لمقياس خصائص التفكير الإيجابى لدى العينــة الاســنطلاعية

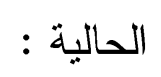

أولاً : صدق المقياس : المد

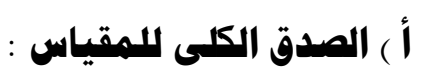

تم حساب الصدق الكلي لمقياس خصائص التفكير الإيجابى عن طريـق : نقانق حساب معاملات الارتباط بين المفردات التي تم الإبقاء عليها وبعدي المقياس ،

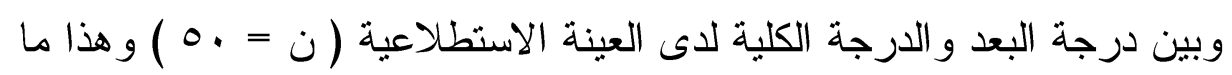

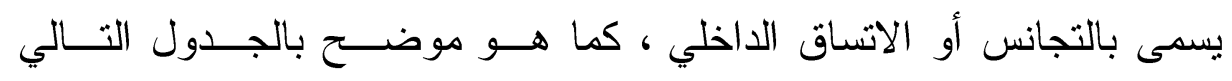

$$
\text { رقم (0) }
$$

جدول ( ) معاملات ارتباط المفردات خصائص التفكير الإيجابى

\begin{tabular}{|c|c|c|c|c|c|}
\hline تحمل المسئولية & رقم & الثقة بالنفس & رقم & حل المشكلات & رقم المفردة \\
\hline$* *,, \vee \vee 4$ & 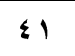 & $* *, \vee \vee \diamond$ & $r$ & $* *, \wedge \div 9$ & 1 \\
\hline$* *, \vee \vee \diamond q$ & $\varepsilon r$ & $* *, 01 r$ & $r r$ & $* *, \wedge \leq \varepsilon$ & $r$ \\
\hline "** & $\varepsilon r$ & $* * *, 0 \leq 7$ & $r r$ & ***, , VA & $r$ \\
\hline$* *,, \varepsilon 0$ & $\varepsilon \varepsilon$ & $* *, T \vee T r$ & $r \varepsilon$ & $* *, 9 r 1$ & $\varepsilon$ \\
\hline *** א ז & $\leqslant 0$ & $* *,\{00$ & ro & $* *, \vee \vee \&$ & - \\
\hline$* *, \vee V \leqslant 1$ & $\leqslant 4$ & & rq & ***, • • & 4 \\
\hline
\end{tabular}


فاعلية برناهج تدريبى لتنسية بعض خصائص التفكير الإيجابى

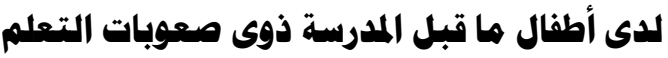

\begin{tabular}{|c|c|c|c|c|c|}
\hline تحمل المسئولية & رقم & الثقة بالنفس & رقم & حل المشكلات & رقم المفردة \\
\hline$* *,, \vee \vee Y$ & $\leqslant 1$ & $* *, \vee \vee \diamond \diamond$ & ri & $* *, \wedge \uparrow 9$ & 1 \\
\hline$* *, \vee \vee \diamond q$ & $\varepsilon r$ & $* *, 01 r$ & $r r$ & $* *,, \wedge \leq \varepsilon$ & $r$ \\
\hline$* *, \pi r r$ & $\varepsilon r$ & $* *, 0 \leqslant 7$ & $r r$ & $* *, v \wedge r$ & $r$ \\
\hline$* *,, \leqslant 0$. & $\varepsilon \varepsilon$ & $* *,, T \vee r$ & $r \leq$ & $* *, 941$ & $\varepsilon$ \\
\hline א א & $\leqslant 0$ & $* *, \leqslant \diamond 0$ & ro & $* *, V \bullet \varepsilon$ & • \\
\hline$* *,, \vee \leq 1$ & $\leqslant 4$ & & rt & **, , ^r॰ & 7 \\
\hline$* *,, 0 \vee 4$ & $\leqslant V$ & & $r v$ & $* *,, 0 \wedge 9$ & v \\
\hline$* *, r q \wedge$ & $\varepsilon \wedge$ & $* *, T r V$ & rᄉ & $* *, 0 \leqslant \varepsilon$ & $\wedge$ \\
\hline א אזד • & $\leqslant 9$ & $* *, \wedge r V$ & $r q$ & $* *, 0 \leq 1$ & 9 \\
\hline$* *, 0 \mathrm{r} \Lambda$ & o. & $* *, \vee \vee \vee V$ & $r$. & & 1. \\
\hline$* *, \vee \vee \vee \bullet$ & 01 & $* *, 00 \leqslant$ & M & $* *$, or V & 11 \\
\hline$* *, \vee \vee \vee V$ & or & $* *, 0 \wedge \uparrow$ & Mr & $* *, \Upsilon \uparrow \Lambda$ & ir \\
\hline$* *,, \varepsilon, \Lambda$ & or & **, , or & $r r$ & $* *, \circ \mathrm{V}$ & ir \\
\hline 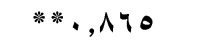 & o & $* *,, V \leq \varepsilon$ & $r \varepsilon$ & $* *,, 0 \wedge 9$ & $1 \varepsilon$ \\
\hline$* *, \wedge \leq \zeta$ & 00 & $* *$, orr & ro & $* *, 09$. & 10 \\
\hline$* *, V \cdot V$ & 07 & $* *, \vee \vee \curlyvee q$ & צו & $* *, 794$ & 17 \\
\hline$* *, \vee \vee q r$ & ov & $* *, \Upsilon . V$ & rV & $* *, \Upsilon \wedge \wedge$ & iv \\
\hline$* *, v i v$ & $0 \wedge$ & $* *, \wedge \cdot \Lambda$ & rᄉ & $* *,, \varepsilon r r$ & 11 \\
\hline$* *, \vee \vee \diamond q$ & 09 & $* *,, \Delta \wedge \vee$ & $r q$ & $* *, \leqslant \circ r$ & 19 \\
\hline$* *, \circ r$ & 9. & $* *,, \vee r r$ & $\varepsilon$. & $* *$, * \1 & $r$. \\
\hline
\end{tabular}

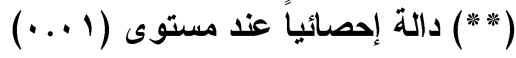

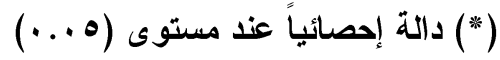

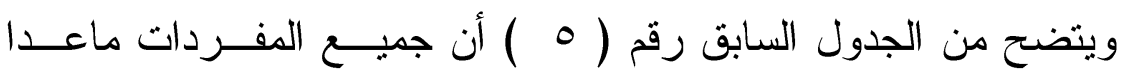

المفردة رقم ( • ( ) لعدم صدقها تتتمي لخاصية حل المشكلات مرتبطة بهــذا البعد ارتباط دال إحصائياً عند مستوى (1 ( . •) ، كما تبين أن جميع المفردات

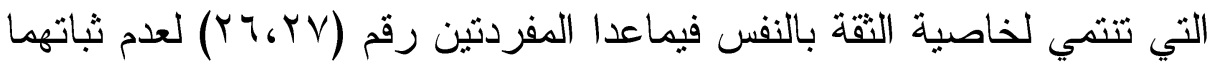
بالمقياس ترتبط ارتباطاً دالاً إحصائياً عند مستوى (1 (. . ) ، كما كانت جميع المفردات التي تتتمي لخاصية تحمل المسئولية مرتبطة بهذا البعد ارتبــاط دال

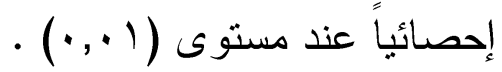


كما تم حساب معامل الارتباط بين الأبعاد الثلاثثة لخصــائص التفكيـر

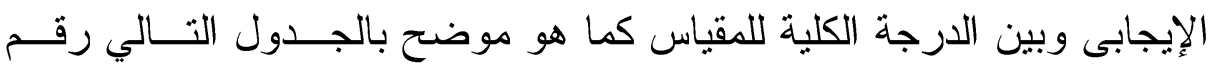

جدول ( 7 ) معاملات الارتباط بين الخصائص الثلاثة للتفكير الإيجابى والدرجة الكلية للمقياس

\begin{tabular}{|c|c|}
\hline الدرجة الكلية & معاملات الارتباط \\
\hline$* *, \wedge T$ & حل المشكلات \\
\hline$* *, \wedge+4$ & الثقة بالنفس \\
\hline$* *, \wedge \wedge \mu$ & تحمل المسئولية \\
\hline$* *, 907$ & الارجة الكلية \\
\hline
\end{tabular}

ويتضح من الجدول السابق وجود إرتباط دال إحصائياً عند مستوى دلالة (1 +. •) بين خاصية حل المشكلات و الدرجة الكلية لمقياس خصائص التفكير

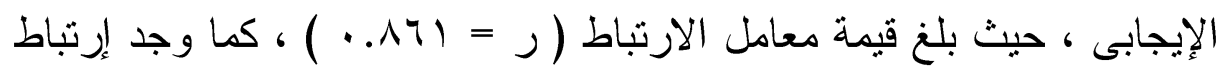
دال إحصائياً عند مستوى ( (.,. ) بين خاصية الثقة بالنفس و الدرجة الكلية للمقياس ، حيث بلغ قيمة معامل الارتباط ( ر= بسم, · ) ، بالإضافة إلى أنه وجد إرثباط دال إحصائياً عند مستوى (1 +..) بين خاصية تحمل المسئولية

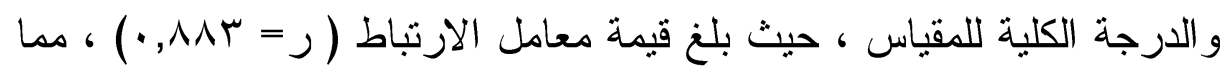
يشير إلي اتساق البناء الداخلي ، الأمر الذي يؤكد على صدق تكوين المقياس الحالي لقياس خصائص التفكير الإيجابى •

\section{ب ) صدق المكمين :}

ويعنى صدق المقياس قدرته على قياس ماوضع من أجله ولتحديد مــدى

صدق محتوى المقياس قامت الباحثة بعرض هذا المقياس بخصائص المــراد

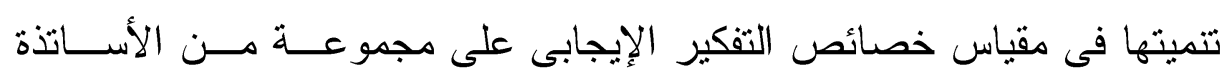

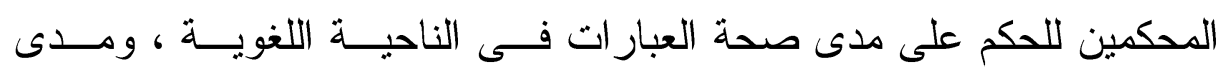




\section{فاعلية برنامج تدريبى لتنهية بعض خصائص التفكير الإيجابى}

لدى أطفال ها قبل المدربة ذوى صعوبات التعلم

صلاحية العبار ات ومناسبتها مع للأطفال ذوى صعوبات التعلم ، وكانت نتيجة

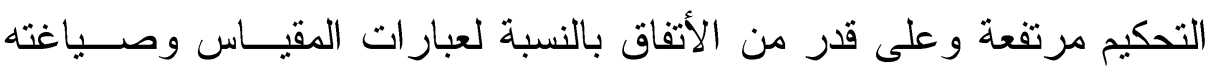

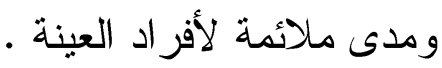

0) برناهج تدريبى قائم على تنسية بعض خصائص التفكير الإيجـابى لـدى الأطفال ذوى صعوبات التعلم ( إعداد / الباحثة )

قامت الباحثة بإعداد برنامج تدريبى ، لتتمية بعض خصــائص التفكيـر

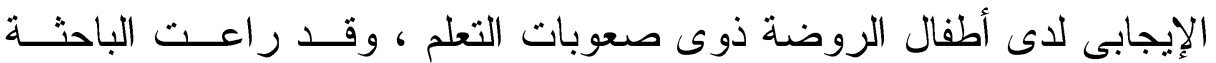
خصائص هؤلاء الأطفال و إحتياجاتهم وقدر اتهم و إمكاناتهم ، كما راعـــ أن يعمل البرنامج التدريبى على تتمية بعض خصائص التفكير الإيجــابى لــديهر و هى ( حل المشكلات ، الثقة بالنفس ، تحمل المسئولية ) مما يـنـكس علـى أدائهم وسلوكياتهم وخصائصهم من خلال أنشطة البرنامج المقدمة .

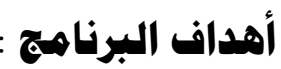

() تتمية خصائص التفكير الإيجابى لدى الأطفال ذوى صعوبات التعلم والتى تتمثل فى ( حل المشكلات ، الثقة بالنفس ، تحمل المسئولية ) . r) تدريب الأطفال ذوى صعوبات التعلم على حل المشكلات التى تو اجهرم . r) تزويد وتتمية الثقة بالنفس لدى هؤلاء الأطفال . ع) تنمية قدراتهم على تحمل المسئوولية والإعتماد على النفس . الأسس التى يقوم عليها البرناهج التدريبى : ( ) الأسس النفسية . r) الأسس التربوية والإجتماعية . 


\section{خطوات بناء البرناهم التدربيبى :}

( ) الإطلاع على الأدبيات و الدر اسات التى إهتمت بمتغيرات البحث . r) الإطلاع على عدد من المر اجع و المصادر التى تتاولت بالشرح و التفســير لخصائص التفكير الإيجابى .

r) إجر اء الدراسة الإستطلاعية للتعرف على خصائص العينة وهم الأطفــال

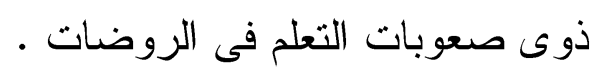

ع) إعداد الأنشطة التى تتناسب مع موضوع البرنامج و التى تشــعى لتنميـة خصائص التفكير الإيجابى لاى الأطفال ذوى صعوبات التعلم .

\section{همتوى البرنامهج :}

يحتوى البرنامج التذريبى على مجموعة من الأنشطة التى تعمل علـى

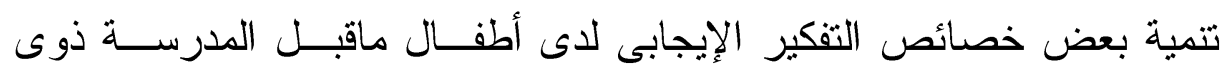

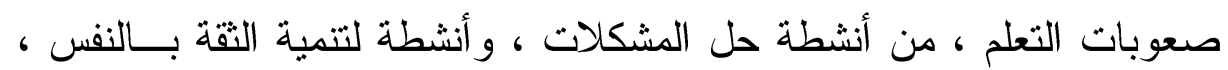
و أنشطة لتتمية تحمل المسئولية ، ويحتوى البرنامج لتتمية هـــه الخصــائص على مجموعة من الأنشطة المتتوعة منها الحركيــة و القصصـية و العلميــة

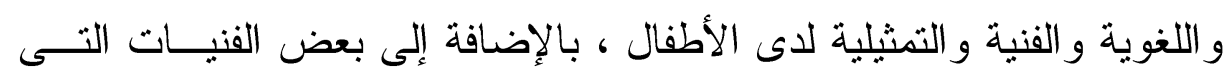
قامت الباحثة باستخدامها مثل النمذجة و الإكتشاف الموجه و الحوار و المناقشــة و اللعب التعاونى و التعلم المبرمج وطريقة اللعب و السيكودر اما وتعزيز الأطفال على أدائه بالأنشطة .

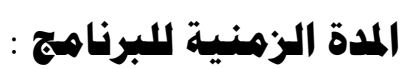

إستغرق تتفيذ أنشطة البرنامج التذريبى ثلاثة أثهر فى الفصل الدراسى

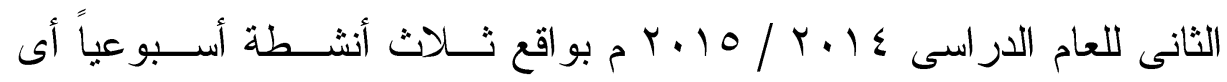
مايعادل · ب نشاط مدة كل نشاط تثر اوح بين . ( $7 .-\varepsilon 0)$ 


\section{أساليب تقويم البرناهمج :}

التقويه البنسائى : أثناء تدريب الأطفال وتقويمهم فى نهاية كل نشاط للتأكد من

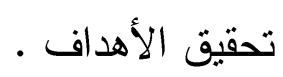

التقويـ النهائى : بعد نظبيق البرنامج يتم تطبيق مقياس خصـــائص التفكيـر

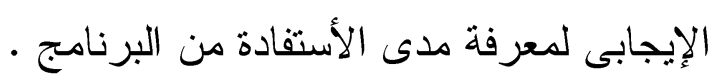

الأساليب الأهصائية :

$$
\text { • • إختبار مان _ إختبار ويلككسون • }
$$

• معامل إرتباط جتمان وسبيرمان •

• معادلة ألفا كرنباخ.

\section{هناقشة نتائج البحث وتفسيرها :}

معالجة الفروض الإهصائية :

إختبار ( التحقق هن ) صحة الفرض الأول :

لإختبار صحة الفرض الأول الذي ينص على أنه " لا يوجد فــرق دال

إحصائياً بين متوسطي رتب درجات المجموعة التجريبية و المجموعة الضابطة على مقياس خصائص التفكير الإيجابى لطفل الروضة " ، اســتخدت الباحثــة اختبار مان ويتتي Mann-Whitney لعينتين مسـتقلتين بو اســطة برنــامج الحزمة الاحصائية للعلوم الإجتماعية 20 SPSS V. لحساب دلالة الفروق بين متوسطي رتب درجات المجموعة التجريبية و المجموعة الضابطة على مقياس خصائص التفكير الإيجابى و أبعاده الفرعية ، ويوضح الجدول التالي رقم (V) نتائج هذا التحليل : 


\section{جل ج (v )}

يوضح نتائج تحليل اختبار مان ويتني للفروق متوسطي رتب درجات المجموعة التجريبية و المجموعة الضابطة فى القياس القبلى على مقياس خصائص التفكير الإيجابى وأبعاده الفرعية دئية

\begin{tabular}{|c|c|c|c|c|c|c|c|c|c|}
\hline \multirow[b]{3}{*}{ الدلالة } & \multirow[b]{3}{*}{ 忽 } & \multirow{3}{*}{ 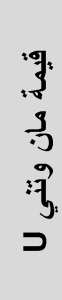 } & \multicolumn{6}{|c|}{ المجموعة } & \multirow[t]{3}{*}{ العينة } \\
\hline & & & \multicolumn{3}{|c|}{ التجريبية } & \multicolumn{3}{|c|}{ الضابطة } & \\
\hline & & & $\begin{array}{l}\text { 子. } \\
\text { w } \\
\overline{3} \\
\text { 马. }\end{array}$ & $\begin{array}{l}\text { 多 } \\
\text { 年 } \\
\overline{3} \\
\text { 马. }\end{array}$ & $\overline{7}$ & $\begin{array}{l}\text { 子. } \\
\text { w } \\
\overline{3} \\
\text { 子. }\end{array}$ & $\begin{array}{l}\frac{3}{3} \\
\frac{3}{3} \\
\overline{3}\end{array}$ & 承 & \\
\hline$\gtreqless$ & $\frac{2}{3}$ & $\frac{0}{2}$ & $\begin{array}{l}\dot{0} \\
\dot{z} \\
z\end{array}$ & $\begin{array}{l}0 \\
2 \\
2\end{array}$ & $\therefore$ & $\begin{array}{l}\dot{0} \\
\dot{z} \\
<\end{array}$ & $\begin{array}{l}2 \\
z \\
z\end{array}$ & $\therefore$ & حل المشكلات \\
\hline$\stackrel{\Xi}{:}$ & 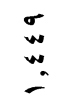 & I & $\underline{z}$ & $\dot{\vdots}$ & $\dot{-}$ & $<$ & $\dot{z}$ & $\dot{-}$ & الثقة بالنفس \\
\hline 年 & $\begin{array}{l}\vdots \\
\vdots \\
:\end{array}$ & $\stackrel{0}{2}$ & $\stackrel{0}{=}$ & $\begin{array}{l}2 \\
=\end{array}$ & $\therefore$ & $\dot{0}$ & $\begin{array}{l}0 \\
\vdots\end{array}$ & $\dot{-}$ & تحمل المسئولية \\
\hline$\stackrel{\circ}{\vdots}$ & 5 & $\leq$ & $z$ & $\dot{\Sigma}$ & $\dot{-}$ & $2^{2}$ & $i$ & $\therefore$ & الدرجة الكلية \\
\hline
\end{tabular}

لاحظت الباحثة فى الجدول (V) أن هناك عدم وجود فروق بين أطفال المجموعة التجريبية و أطفال المجموعة الضابطة على مقباس خصائص التفكير الإيجابى وذلك لأنه لم يتم تطبيق أى أنشطة من أنشطة البرنامج على أطفــال المجموعة التجريبية وهم الأطفال ذوى صعوبات التعلم الذين يسعى البرنــامج لتتمية بعض خصائص التفكير الإيجابى لديهر .

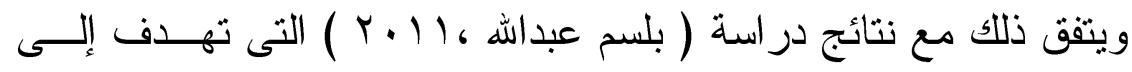
تتمية مهارة حل المشكلات لدى أطفال ما قبل المدرســـة ، ونتــائج دراســة ( إيناس أبو بكر ، ع ( • ) التى تهدف أيضا إلى التعرف على فاعلية برنامج الكمبيوتز المستخدم فى الدراسة لتمية مهارة حل المشــكلات لـدى أطفــال 


\section{فاعلية برناهمج تدرببى لتنسمية بهض خصائص التفكير الإيبابى}

لدى أطفال ها قبل المدرسة ذوى صعوبات التعام

الروضة ذوى صعوبات التعلم ، و أكــدت در اســة (Goldberg,C., 2005) على تتمية مهار ات حل المشكلات لدى عينة من أطفال ذوى صعوبات الــتعلم من خلال برنامج كمبيوتري مقترح وتتمية الثقة بالنفس مــن خــلال التغذيــة الر اجعة وتدريب الطفل على مهار ات حل المشكلات التى يبدأ من إثارة حــب الاستطلاع وتفسير الحلول و الثقة بالنفس ، مهارة حل المشكلات لدى هــؤلاء

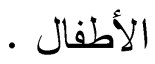

كما اهتمت الباحثة أيضاً بعمل أنشطة لتتمية الثقة بالنفس لدى الأطفــال ذوى صعوبات التعلم التى تشجع على وتتمية دافعية الإنجــاز لــديهر و الثقـــة بالنفس ويتفق ذلك مع نتائج دراسة ( عمرو على ، Y ا . Y ) و التى أسـفرت نتائجها عن وجود فروق ذات دلالة إحصائيا بين متوســطات رتــب أطفــال الروضة ذوى صعوبات التعلم فى القياسين القبلى و البعدى على أبعاد مقبــاس دافعية الإنجاز ( السعى نحو التفوق و النجاح ، الثقــة بــالنفس ، و المثــابرة )

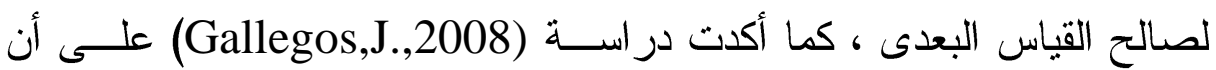
الأطفال ذوى صعوبات التعلم يعانون من الإحباط ، وترى و القلق وحثت هذه رهات

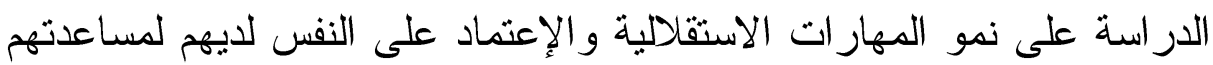

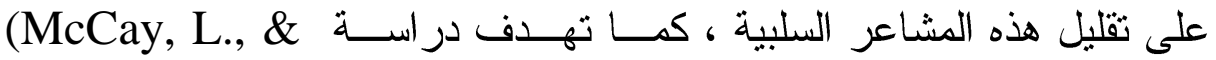
Keyes, D.,2001,pp.70-78) صعوبات التعلم من خلال تتمية بعض المهارات المتمثلة فـى الاســتقلالية ، و تأكيد الذات ، و الحساسية الإجتماعية ، وبنـــاء الصـــاقة ومهــار ات حـل

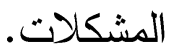

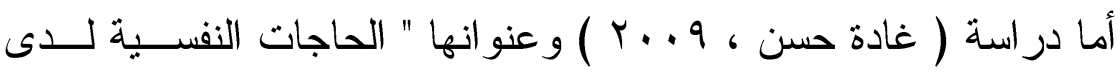

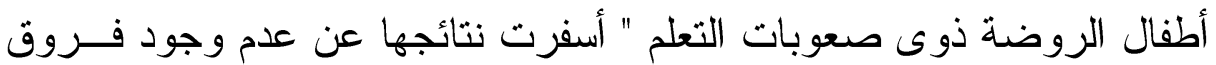
بين متوسطات رتب درجات الأطفال مرتفعى ومنخفضى صعوبات التعلم فى 
درجة إثباع الحاجات النفسية بالنسبة لجميع الأبعاد ( الإستقلالية - الكفاءة الإنتماء- الدرجة الكلية للحاجات النفسية ) .

لذلك فقد قدمت الباحثة أيضاً بعض الأنشطة التى تنمى تحمل المســؤلية و الأعتماد على النفس من خلال أداء الأطفال لانشطة البرنامج.

$$
\text { جدول ( } 1 \text { ) }
$$

يوضح نتائج تحليل إختبار مان ويتني للفروق متوسطي رتب درجات المجموعة التجريبية و المجموعة الضابطة فى التطبيق البعدى على مقياس خصائص التفكير الإيجابى وأبعاده الفرعية

\begin{tabular}{|c|c|c|c|c|c|c|c|c|c|}
\hline \multirow[b]{3}{*}{ مستوى } & \multirow[b]{3}{*}{ "S." } & \multirow{3}{*}{ 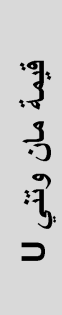 } & \multicolumn{6}{|c|}{ المجموعة } & \multirow[t]{3}{*}{ العينة } \\
\hline & & & \multicolumn{3}{|c|}{ التجريبية } & \multicolumn{3}{|c|}{ الضابطة } & \\
\hline & & & $\begin{array}{l}\frac{d}{3} . \\
\frac{1}{3} \\
\overline{3} .\end{array}$ & $\begin{array}{l}\text { 年 } \\
\text { 年 } \\
\overline{3} .\end{array}$ & $\overline{7}$ & $\begin{array}{l}\frac{d}{3} \\
\frac{a}{3} \\
\frac{3}{3} .\end{array}$ & $\begin{array}{l}3 \\
\frac{3}{3} \\
\overline{3} \\
\overline{3}\end{array}$ & $\overline{7}$ & \\
\hline$\vdots$ & $\begin{array}{l}z \\
z\end{array}$ & $\vdots$ & $\stackrel{0}{:}$ & $\begin{array}{l}\therefore \\
\therefore \\
\therefore\end{array}$ & $\therefore$ & $:$ & $\therefore$ & $\therefore$ & حل المشكلات \\
\hline$\vdots$ & $\sum_{i}$ & $\vdots$ & $\stackrel{0}{0}$ & $\begin{array}{l}0 \\
0 \\
0\end{array}$ & $\therefore$ & $:$ & $\because$ & $\therefore$ & الثقة بالنفس \\
\hline$\vdots$ & $\ddot{z}$ & $\vdots$ & $\stackrel{0}{0}$ & $\begin{array}{l}0 \\
\vdots \\
0\end{array}$ & $\dot{-}$ & $:$ & : & $\dot{-}$ & المسئولية \\
\hline$\vdots$ & $\stackrel{\dot{\sigma}}{2}$ & $\vdots$ & $\stackrel{0}{0}$ & $\begin{array}{l}\vdots \\
\therefore \\
\therefore\end{array}$ & $\dot{-}$ & $:$ & $\therefore$ & $\div$ & الدرجة الكلية \\
\hline
\end{tabular}

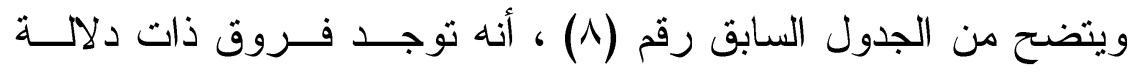

إحصائية بين متوسطات رتب درجات كل من أطفال المجموعــة التجريبيـة ودرجات المجموعة الضابطة على مقياس خصائص التفكير الإيجابى لصــالح القياس البعدى ، وذللك من خلال تطبيق البرنامج علــى أطفــال المجموعــة التجريبية و أنشطة البرنامج التى زودتهم بحصائص التفكير الإيجابى من خلال 


\section{فاعلية برنامج تدريبى لتنهية بعض خصائص التفكير الإيجابى}

لدى أطفال ها قبل المدربة ذوى صعوبات التعلم

إكسابهم القدرة على حل المشكلات وتزويدهم بالتقة بالنفس وتحمل مسـئولية انفسهم داخل وخارج الروضة .

كما حققت الباحثة أيضا بعض الأهداف التى أتفقت مع الدر اسات الأتية : در اسة (McGuinness, C.,2013 ) ، و (زينب درديــرى ، زينـبـ

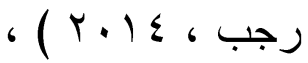

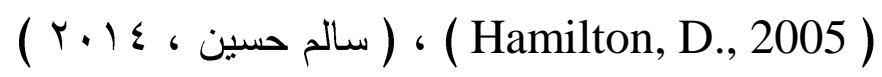

، (Bob,A, et، al.,2012) ( Hill,s. ,2014) Telzrow, C., \& Bonar, A. , (Y. ( أســماء محمــ عـدلان ، (1) ) • ( Kamann, M., \& Wong, B.,1993) ، (2002,pp.8-13) إختبار ( التحقق هن ) صحة الفرض الثالث : لإختبار صحة الفرض الثالث الذي ينص علــى أنـــهـ "' توجــــــــروق ذات دلالة إحصائية بين متوسط رتــب درجــات أطفــال المجموعـــة التجريبيــة فى القياس القبلى و البعــدى علــى مقيــاس خصـــائص التفكيــر الإيجــابى و أبعادة الفرعية لصالح التطبيق البعدى" وللتحقق من صــحة هــذا الفــرض ، تمت مقارنة متوسط رتب درجـات أطفــال المجموعــة التجريبيــة قبــل تطبيق البرنامج ، بمتوسط رثب درجــات نفـس المجموعــة بعـــ ثطبيــق

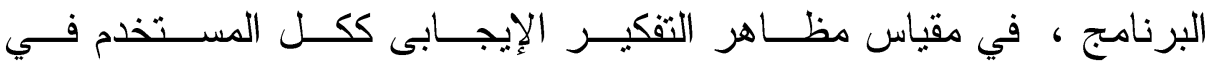

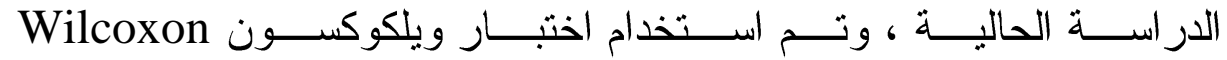
اللابار امتزي للكثف عن دلالة الفروق بــين التطبيقـين القبلــي و البعـــي لعينة الدر اسة ـ ويوضح الجدول ( 9 ) ما توصلت إليه النتائج : 


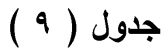

متوسط ومجموع الرتب السالبة والموجبة وقيمة Z بين القياسين القبلي والبعدي لأطفال المجموعة التجريبية علي الارجة الكلية ( لكقياس مظاهر التفكير الإيجابى ) بطريقة ويلكوكسون

\begin{tabular}{|c|c|c|c|c|c|}
\hline \multirow{2}{*}{ دلالتها } & \multirow{2}{*}{ قيمة $z$} & \multicolumn{2}{|c|}{ القياس القبلي / البعدي } & \multirow{2}{*}{ (ن) } & \multirow{2}{*}{ متغير رتب } \\
\hline & & مجموع الرتب & متوسط الرتب & & \\
\hline \multirow{4}{*}{, , . } & \multirow{4}{*}{$r, \Lambda . \diamond-$} & $00, \ldots$ & 0,0 . & 1. & الرتب السالبة \\
\hline & & . & . & . & الرتب الموجبة \\
\hline & & . & - & . & الرتب المحايدة \\
\hline & & & & 1. & المجموع الكلي \\
\hline
\end{tabular}

يتضح من الجدول السابق وجود فروق ذات دلالة إحصائية عند مستوي دلالة ( 0... ) بين متوسطات رثب درجات أطفال المجموعة التجريبية قبل وبعد نطبيق البرنامج علي مقياس مظاهر التفكير الإيجابى ككل المستخدم في الدراسة الحالية ، لصالح التطبيق البعدي ، حيث بلغت قيم Z بين

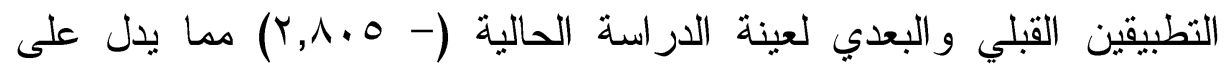
تحقق صحة الفرض الثالث .

\section{(1) (1) (1) (1)}

شكل ( 1 ) يوضح الفروق بين التطبيقين القبلي والبعدي للمجموعة التجريبية على مقياس خصائص التفكير الإيجابى وأبعادة الفرعية لصالح التطبيق البعدى التئي

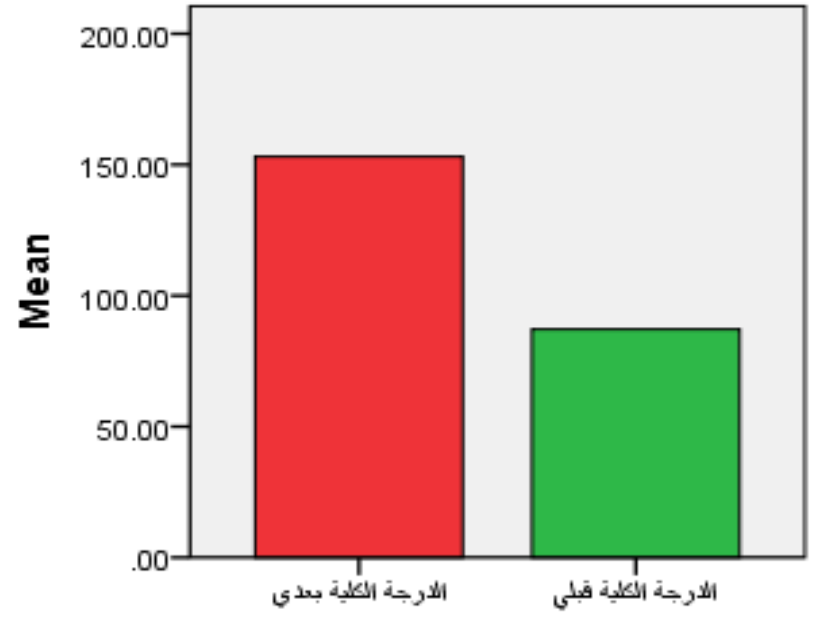


يتضح مما سبق تحقق الفرض الخامس حيث كانت قيمة (Z) لالالـــة

الفروق بين متوسطات رتب درجات أطفال المجموعة التجريبية على الدرجة الكلية لمقياس خصائص التفكير الإيجابى فى التطبيقين القبلى و البعدى لصالح التطبيق البعدى، مما يشير إلى تحقيق البرنامج لتنمية مظاهر التفكير الإيجابى للأطفال ذوى صعوبات التعلم من أطفال المجموعة التجريبية و الذى أدى إلـى ارتفاع متوسطات رتب درجات أطفال المجموعة التجريبية فى الدرجة الكليـة لمقياس خصائص التفكير الإيجابى فى التطبيق البعدى. وللتحقق من حجم تأثير البرنامج المستخدم في تتمية مظاهر التفكيــر

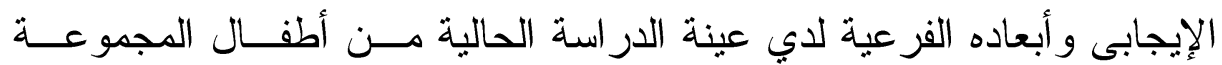
التجريبية، تم حساب معامل الارتباط الثنائي لرتب الأزواج المرتبطة (rprb) فــ Matched- Pairs Rank biserial correlation متز ابطتين وذلك عند استخدام اختبار ويلكوكســون لحســاب الفـروق بـين متوسطي رتب أزواج الدرجات المرتبطة من البيانات الحالية وفقــاً للمعادلــــة التالية : - الت

$$
r_{\mathrm{prb}}=\frac{4\left(\mathrm{~T}_{1}\right)}{\mathrm{n}(\mathrm{n}+1)}-1
$$

حيث (rprb) يعبر عن قوة العلاقة (معامل الارتبــاط الثتــائي لرتــبـ

$$
\text { الأزواج المرتبطة) }
$$

$$
\begin{aligned}
& \text { ترمز إلى مجموع الرتب ذات الإشارة الموجبة } \\
& \text { و n إلى عدد أزواج الدرجات . }
\end{aligned}
$$

ويوضح الجدولين التاليين حدود حجم التــأثير وفقــاً (rprb) معامـلـل الارتباط الثنائي لرتب الأزواج المرتبطة ، وحجم تأثير البرنامج المستخدم في 
تتمية ماور اء المعرفة و أبعاده الفرعية لاي أفر اد العينة وفقاً (rprb) على النحو

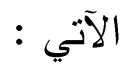

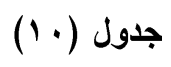

يوضح حدود التأثير وفقا (rprb) معامل الارتباط الثنائي لرتب الأزواج المرتبطة

\begin{tabular}{|c|c|}
\hline$\left(r_{p r b}\right) !$ & الحدود \\
\hline$. . \varepsilon>r_{\text {prb }}$ & ضعيف \\
\hline$\cdot v>r_{\text {prb }} \geq \cdots \varepsilon$ & متوسط \\
\hline$. .9>r_{\text {prb }} \geq . . v$ & قوي \\
\hline$r_{p r b} \geq . .9$ & قوي جدا \\
\hline
\end{tabular}

$$
\text { جدول (11) }
$$

يوضح نتائج حجم التأثير البرنامج المستخدم في تنمية مظاهر التفكير الإيجابى وأبعاده

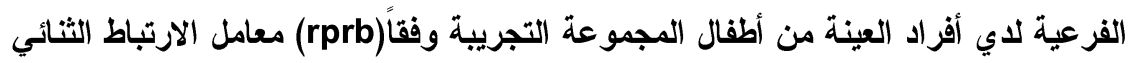

\begin{tabular}{|c|c|c|}
\hline نوعه & 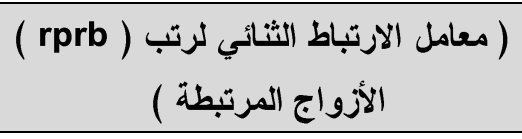 & المتغير \\
\hline قوي جدا & 1 & الارجة الكلية "مقياس مظاهر الإيجابى و أبعادة \\
\hline
\end{tabular}

$$
\text { لرتب الأزواج المرتبطة }
$$

ويتضح في ضوء الجدول السابق أن حجم تــأثير البرنــامج الحــالي

للار اسة في تتمية مظاهر التفكير الإيجابى وأبعاده الفرعية لدي أفــر اد عينــة

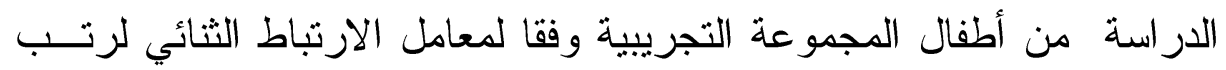

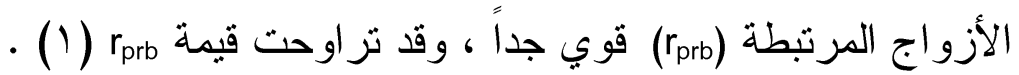
ويمكن تفسير هذه النتيجة في ضوء البرنامج المستخدم الذي يتضــمن

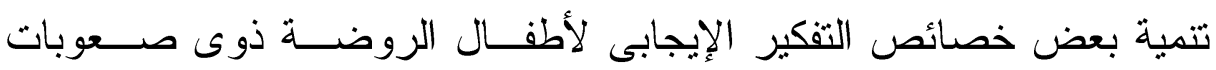

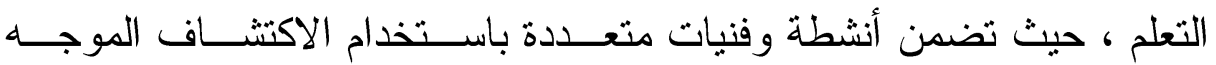


بالإضافة إلى بعض الفنيات الأخرى والأدوات و الوسائل المتتوعة ، كما راعت

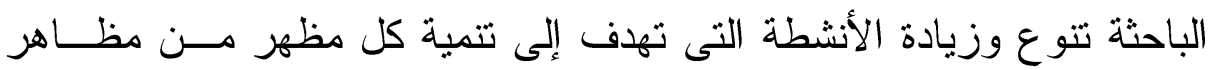
التفكير الإيجابى ، وقد شارك الأطفال بفاعلية في البرنامج •

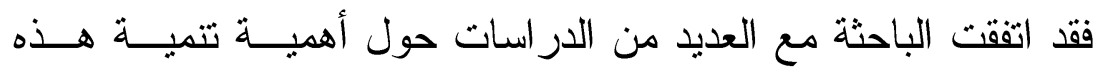
المظاهر لدى طفل الروضة بصفة عامة وطفل ذوى صعوبات التعلم بصــفة خاصة لما لها من أهمية فى تتمية قدرات الطفل على حل المشكلات ، و الثقــة

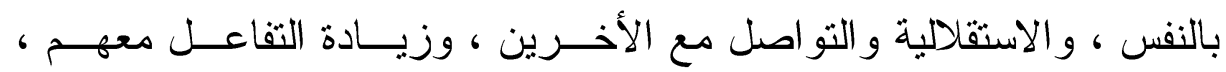

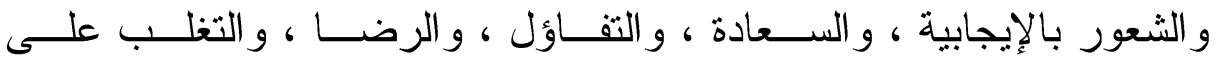

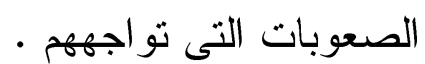
وتركز در اسة (Hill,S.,2014) ) علــى دعــم النمــو الاجتمـــــى و الانفعالى لدى الأطفال ذوى صعوبات التعلم من خلال الأنشطة الفنية لتنميــة المفهوم الإيجابى للذات وتوجية الأطفال إلى التعاون الإيجابى و الثقة بالــذات

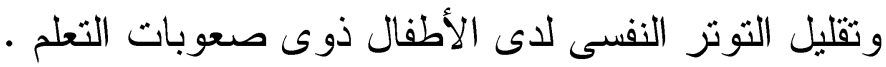
كما لاحظت الباحثة أثناء تطبيق أنشطة البرنامج أن هناك ترابطاً بين المظاهر الثلاثة فكل" منها يخدم الأخر. Arslan, ; Goldberg,C.,2005) ويتفق هذا مع دراسة كلا مــن (E,2010) التى هدفت إلى تتمية مهار ات حل المشكلات لاتى عينة من أطفــال ذوى صعوبات التعلم وتتمية التقة بالنفس ، وقيمة الذات من خــلال التغذيــة

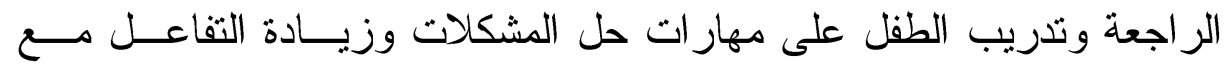
الآخرين و المثل العليا الإيجابية لايهم . وترى در اســة Marttin,et al,1992,p50) أن مهــار ات حـل المشكلات تتضمن اتخاذ القرار وتحمل مسئولية الاختيار و التتفيــذ وتوصــلت نتائجه : الحصول على صورة ذاتية إيجابية ، و التعرف على البدائل المتاحسـة 
له ، التعبير عن الاحتياجات و المشاعر أمام الآخرين ، الاستفادة من المــوارد

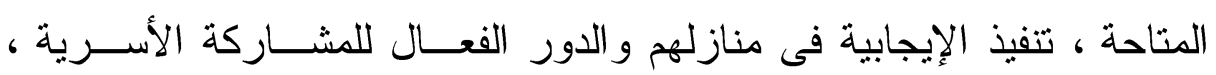

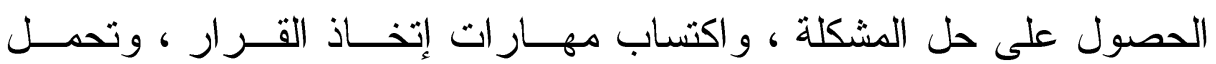

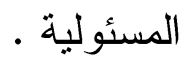

وتشير دراسة (Shepherd,R.,2014) أن هناك بعض الأحتياجـات

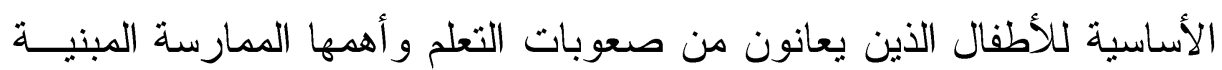
على المعرفة و المهار ات والفهم ، التى تؤدي إلى نتائج إيجابية تتعكس آثار ها على الطفل وعلاقاته بالآخرين وتزيد من ثقته بأنفسهم وثرفع من ثقدير الذات ل لديهم . كما تهدف در اسة ( عبداله ر اغب ، با ـ ب) إلى معرفة درجة كلاً من التقة بالنفس و المسئولية الاجتماعية ، و التحقق من فاعلية البرنامج التـدريبى لتنمية الثقة بالنفس كمدخل لتحسين المسئولية الاجتماعية ، وتعديل السـلوك ، و التبصير بالحلول البديلة التى تساعدهم على مواجهة المشــكلات ، وإيجــاد

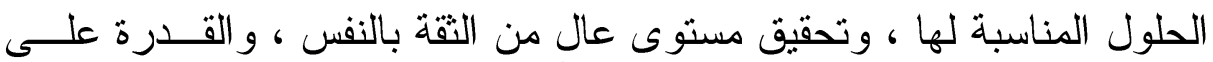
تحمل المسئولية الاجتماعية .

ودر اسة (Kleine, K. ,1991) إلى مساعدة الأطفال ذوى الاحتياجات

الخاصة فى الاعتماد على أنفسهم و التدريب علــى الاســتقلالية ، وتوصــلت نتائجها إلى أهمية دور الأسرة و المجتمع فى تدريب هؤلاء الأطفال على تحمل المسئولية والاعتماد على أنفسهم داخل الروضة وخارجها وذلك مــن خــلال

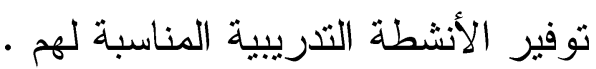
مما سبق نجد أن البرنامج له تأثير إيجابى وفعال فى تتمية المظــاهر

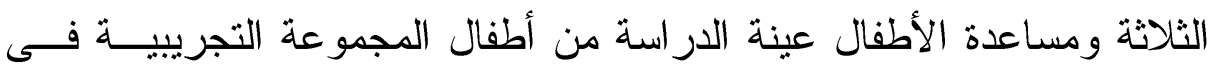
التخلب على الصعوبات وتتمية خصائص التفكير الإيجابى من خــلال تتميــة

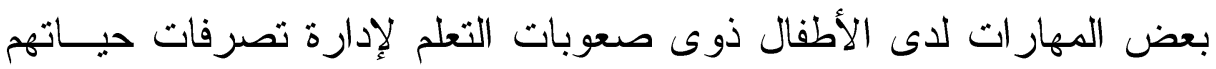




\section{فاعلية برناهج تدريبى لتنمية بعض خصائص التفكير الإيجابى}

\section{لدى أطفال ها قبل المدرسة ذوى صعوبات التعلم}

و إقامة علاقات إجتماعية مع الآخرين ، و الاهتمام بدور المعلمــات و أوليــاء

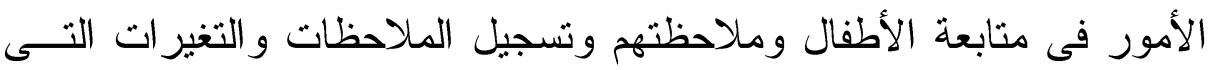
تؤثر على تفكير هم ، وتوفير البيئة المناسبة لهم •

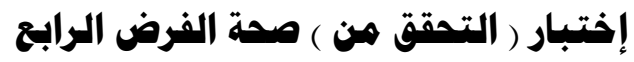

لأختبار صحة الفرض السادس ينص علي أنه " لاتوجد فــروق ذات أترات دلالة إحصائية بين متوسطات رتب درجات أطفال المجموعة التجريبية فـى القياس البعدى بعد تطبيق البرنامج والقياس التتبعى بعد مــرور شـــر مــن إنقضاء البرنامج على مقياس مظاهر التفكير الإيجابى و أبعادة الفرعية . وللتحقق من صحة هذا الفرض ، تمت مقارنة منوسط رتب درجات

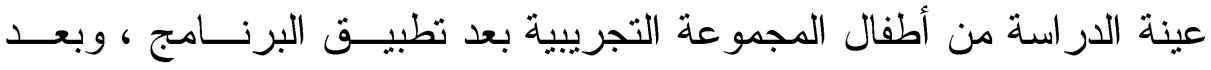
شهرمن التطبيق البعدي علي مقياس خصائص التفكير الإيجابى المستخدم في الدر اسة الحالية ، وتم إستخدام اختبار ويلكوكسون Wilcoxon اللابار امتري

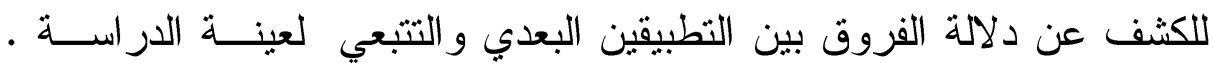
ويوضح الجدول ( 11 ) ما توصلت إليه النتائج :

$$
\text { جدول (11) }
$$

يوضح متوسط ومجموع الرتب السالبة والموجبة وقيمة Z بين القياسين البعدي والتتبعي علي مقياس مظاهر التفكير الإيجابى بطريقة ويلكوكسون

\begin{tabular}{|c|c|c|c|c|c|}
\hline \multirow{2}{*}{ دلالتها } & \multirow{2}{*}{ ق } & \multicolumn{2}{|c|}{ القياس القبلي / البعدي } & \multirow{2}{*}{ العدد } & \multirow{2}{*}{ 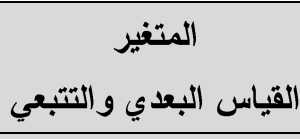 } \\
\hline & & مجموع الرتب & متوسط الرتب & & \\
\hline \multirow{4}{*}{, $11 \varepsilon$} & \multirow{4}{*}{$-1,0 \wedge r$} & $9,0$. & $\varepsilon . V_{0}$ & $r$ & الرتب السالبة \\
\hline & & $r \Delta, 0$. & $0, \cdot V$ & v & الرتب الموجبة \\
\hline & & & & 1 & الرتب المحايدة \\
\hline & & & & 1. & المجموع الكي \\
\hline
\end{tabular}

يتضح من الجدول السابق عدم وجود فروق ذات دلالة إحصائية عند

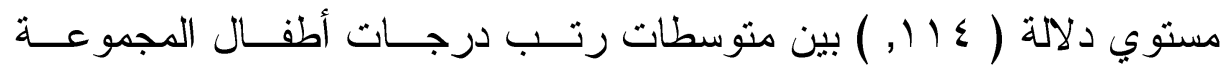


التجريبية فى التطبيقين البعدى و التتبعى على مقياس خصائص التفكير الإيجابى المستخدم فى الدراسة الحالية ، وبلغت قيم Z بين التطبيقين القبلــي و البعـدي لعينة الدر اسة علي مقياس خصائص التفكير الإيجابى ( - 1,0AY ) ) ، مما يدلل علي تحقق الفرض الرابع للار اسة الحالية .

شكل (r)

يوضح عدم وجود فروق بين التطبيقين البعدي و التتبعي علي مقياس مظاهر التفكير الإيجابى

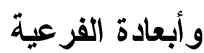

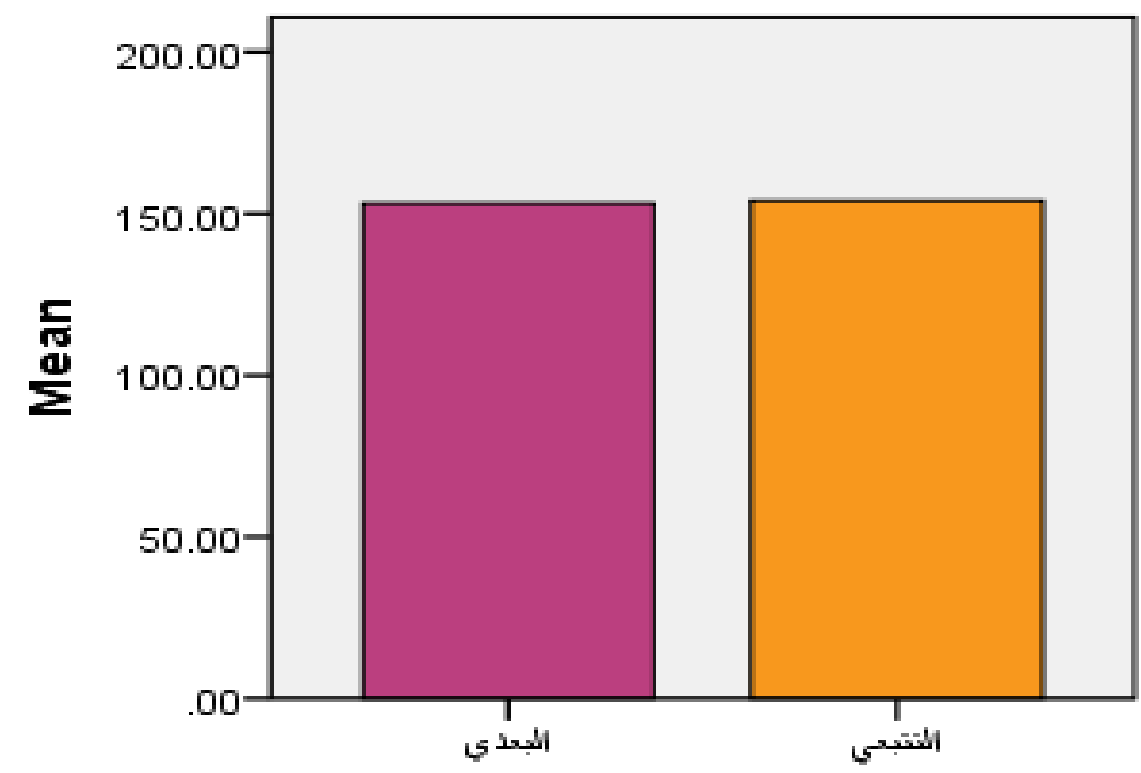

يتضح مما سبق تحقق الفرض السادس حيث كانت قيمة (Z) لدلالــــة

الفروق بين متوسطات رتب درجات أطفال المجموعة التجريبية فى التطبيقين البعدى و التتبعى ( بعد مرور شهرمن تطبيق البرنامج ) على مقياس مظــاهر التفكير الإيجابى غير داله، مما يدل على إستمرار تأثير البرنامج على تتميـة بعض مظاهر التفكير الإيجابى باستخدام الاكتشاف الموجه لأطفال الروضـــة ذوى صعوبات التعلم عينة الدر اسة فيما بعد تطبيق البرنــامج خــلال فتــرة

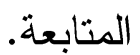




\section{فاعلية برنامهج تدريبى لتنسمية بعض خمائص التفكير الإيجابى}

لدى أطفال هما قبل المدرسة ذوى صعوبات التعام

وترجع الباحثة هذه النتيجة إلى إستمر ار فعالية البرنامج لتتمية بعـض

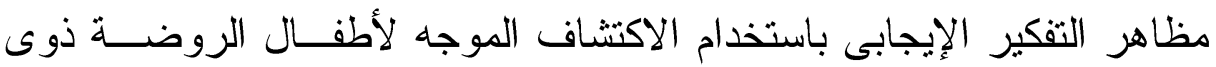

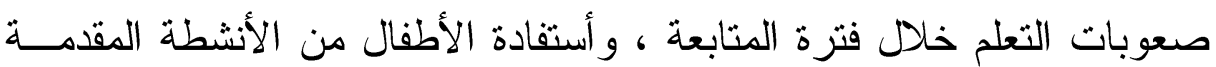
فى البرنامج و الذى ينجم عنها تتمية القدرة على حـلـل المشــكلات ، و الثقـــة بالنفس ، وتحمل المسئولية إلى جانب بعض المهار ات الناتجة عن تتمية هــذه

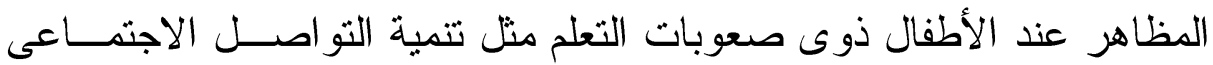
و التفاعل الاجتماعى مع الأقران ، الشعور بالتفاؤل و السعادة ، و إحتر ام الذات و تقدير ها والشعور بالاستقلالية ، و القدرة على إتخاذ القرار فى بعض الألى الأمور ،

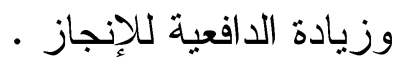

وقد أوضحت ودر اسة (Donohue, J. , 1994) أن التفكير الإيجــابى

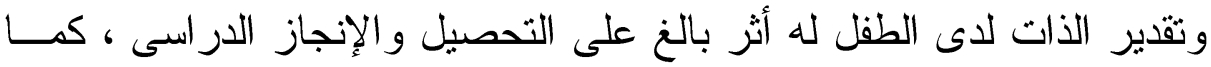

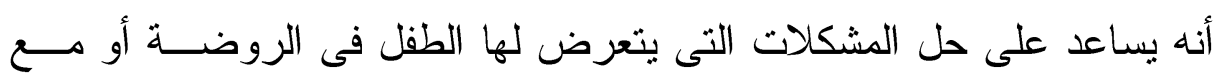
أقر انه .

وحددت در اسة (Kimbrough Jr, R.,1997,p.9-13 ، أمل عبـــ

الغنى ، ب . . r ) بعض السمات الشخصبة لأصحاب التفكير الإيجابى ومن أهم هذه الصفات القيادة ، و القدرة على اتخاذ القرارات الإيجابية، و القدرة على حل العل المشكلات بإيجابية، و الحس السليم و الشجاعة، و الثقــة بــالنفس، و الرعايــة ،

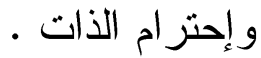

و اهتمت در اسة (Diaz,P. ,2006 ) إلى بناء التقة بــالنفس و إحتــر ام

الذات وتكوين مبادىء التفكير الإيجابى ومعايير التفكير الإيجابى عنــد طفـلـل الروضة تبدأ من قدرته على الثقة بمهار اته و إمكانياته وتقيمه الإيجابى لذاته ، وبيناء البرنامج وجلساته من خلال تدريب الطفل على الثقة بــالنفس وتبنـى مفهوم ذات إيجابى وذلك وصو لا لقدرات التفكير الإيجابى • 
ووضحت دراسة ( عبير عبد الخــالق ، 1... 1 ) أن القبـول مــن

الآخرين لطفل ما قبل المدرسة يتكون من عامل و احد، بينما يتكــون التفكيـر الإيجابى لطفل ما قبل المدرسة من ثلاثة عو امل ، توجد علاقة إرتباطية بـين إجادة القبول من الأخرين لطفل الروضة و التفكير الإيجابى لديه .

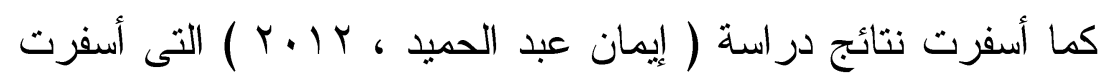
نتائجها عن عدم وجود فروق دالة إحصائياً بين منوسطات رتب درجات أطفال المجموعة التجريبية فى التطبيقى البعدى و التتبعى للبرنامج الإرشادى القـائم على إستر اتيجيات التفكير الإيجابى على مقياس المشكلات السلوكية .

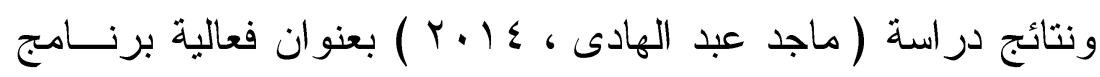

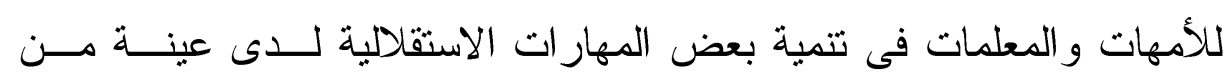
الأطفال ذوى الإعاقة العقلية المتوسطة ، عن عدم وجود فروق دالة إحصــائياً بين متوسطات رتب درجات أفر اد المجموعة التجريبية فى القبــاس البعــى البـ ومتوسطات رتب نفس المجموعة في القياس التتبعى على مقيــاس المهــار ات الأستقلالية .

ودراسة ( أحلام عبد الستار ، (1) ب. ) التى أسفرت نتائجهاعن وجود تأثير دال إيجابياً لبرنامج تتمية مهار ات التفكير فى تتمية بعض الخصــائص النفسية ( الثقة بالنفس - التفاؤل) و الخصائص العقلية ( الطلاقة - الأصالة -

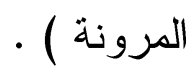

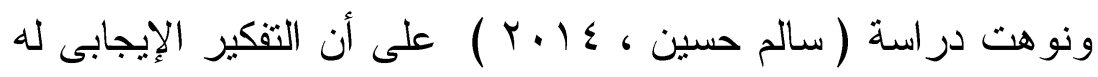
أهميته فى حياة الفرد ، فالتفكير الإيجابى يكسب الفرد الثقة بالنفس و التفاؤل فى ولى المستقبل وسعادة فى الحياة ويستطيع الفرد أن يتغلب على العديد من المشكلات التى تو اجهه ، لذلك على الفرد أن يعمل على اكتساب إبــتر اتيجيات التفكيـر 


\section{فاعلية برناهمج تدرببى لتنسمية بهض خصائص التفكير الإيبابى}

لدى أطفال هما قبل المدرسة ذوى صعوبات التعام

الإيجابى ، وزيادة النواحى الإيجابية فى شخصيته و العمل على توكيد الذات ،

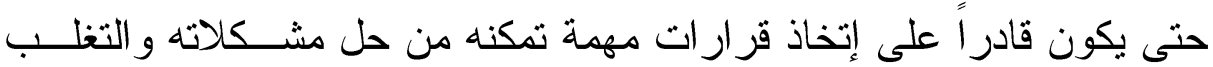
على عثراته ، إستتاداً على قدر اته و على تفكيرة الإيجابى .

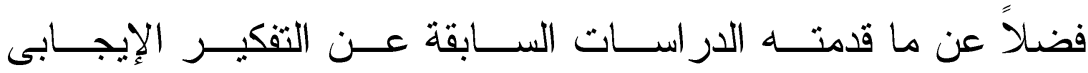
ومظاهرة وما لاحظته الباحثة على الأطفال من تطور تفكبرهم و إنعكاس ذلك على سلوكياتهم والشعور بالتحسن وبتتمية هذه المظاهر الإيجابية لديهم التـى كانو ا مفتقدينها مما جعلهر عرضة لخطر بصعوبات التعلم الاجتماعية وسـلبية التفكير ، ولذلك ترجع الباحثة إستمر ار البرنامج إلى ممارسة الأنشطة و المرور بالبرنامج ، وتركيز البرنامج على نقاط القوة كنقة بدايه لتنمية قدرات الطفل الإيجابية ، وتعزيز الأطفال التعزيز الموجب الذى يعمل على إســتمرار أداء

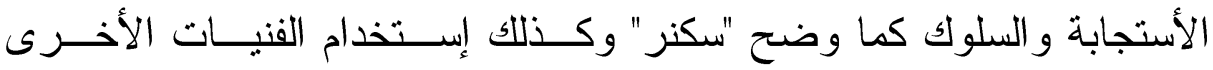
( الحوار و المناقشة ، لعب الأدوار ، اللعب التعاونى ، التعلم المبرمج ) كــان لها أثر هائل فى تتمية مظاهر التفكير الإيجابى ، فتتميــة مظـــاهر التفكيـر الإيجابى لأطفال الروضـة ذوى صعوبات التعلم من شأنها أن تســاعد هــؤلاء الأطفال على اكتساب العديد من المهارات و السلوكيات و المظاهر التى تؤهلهم إلى أن يكونو ا أثخاص إيجابيون فى المستقبل ويشعرون بالتفــاؤل و الســعادة و التفاعل الأجتماعى مع الأخرين بشكل إيجابى والتغلب على الصعوبات التى تو اجههم •

فقد لأحظت الباحثة مدى إستجابة الأطفــال أثثـــاء تطبيــق أنشــطة

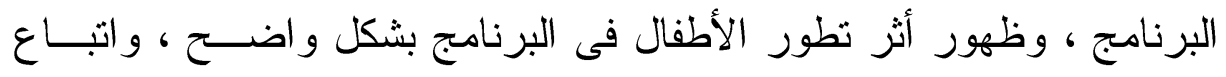
الأطفال إلى الخطو ات و الأجراءات التى تم التدريب عليها فى البرنامج . 


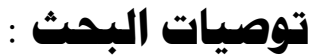

(1) تتجيع معلمات رياض الأطفال على الاهتمام بتتمية التفكير الإيجابى مسن

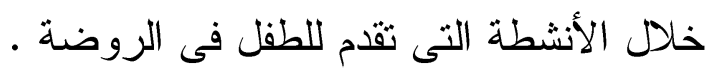

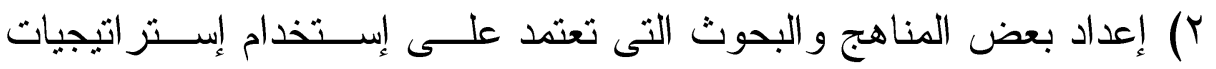
التفكير الإيجابى وتطبيقها فى مختلف المجالات .

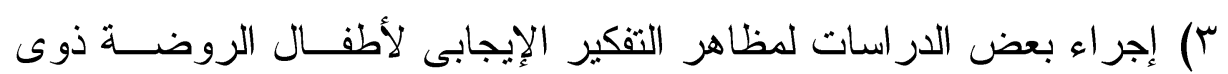

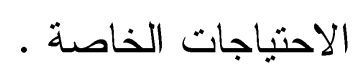

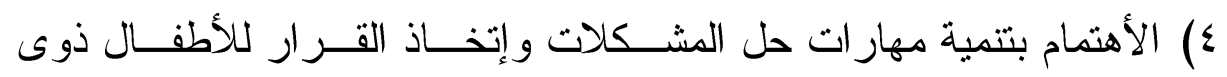

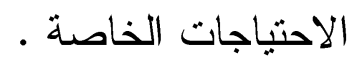

0) الإهتمام بتتمية التقة بالنفس و الدافعية للإنجاز للأطفال ذوى الإحتياجـات . الخاصة . (الاصنام

آ) إجر اء بعض الدراسات التى تهتم بتحمل المسئولية والإستقلالية و المثــابرة

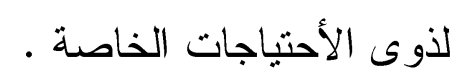

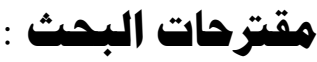

() أثر برنامج تدريبى قائم على التفكير الإيجابى فى تتمية حل المشكلات لاى

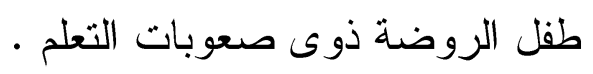

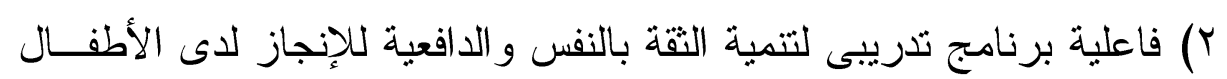
ذوى الإحتياجات الخاصة.

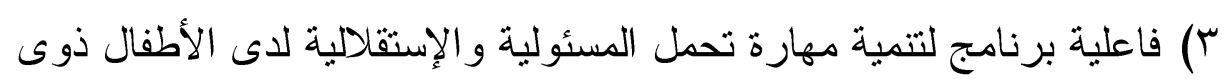

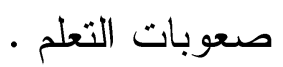


فاعلية برناهم تدريبى لتنهية بعض خصائص التفكير الإيجابى

لدى أطفال ها قبل المدربسة ذوى صعوبات التعلم لئم

\section{بعض نماذج الأنشطة المستخدمهة}

\section{النششاط الأول}

الزهمن : 0 ؛ دقيقة

نهوع النشاط : علمى

عنوان النشاط : إبحث عن اللون المطلوب ( إختلاط الألوان ) .

أهداف النشاط :

( ) أن يصف الطفل المشكلة المعروضة بالنشاط. r) أن يبدى الطفل الرغبة فى حل المشكلة المعروضة أمامة داخل النشاط.

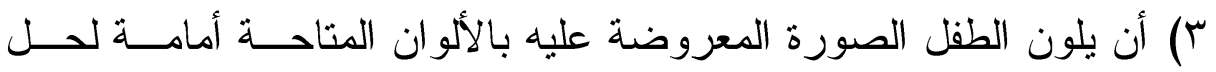
المشكلة المعروضة عليه.

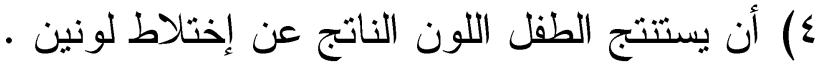

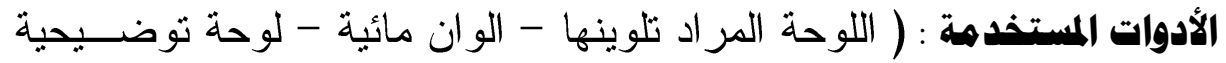

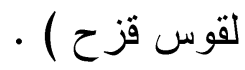
الفنيات المستخدهة : الأكتشاف الموجه _التعزيز.

\section{سير النشاط :}

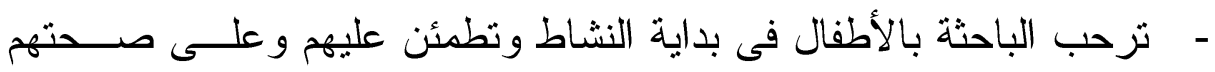
وسلامتهم وتسنرجع معهم موضوع اللقاء السابق . - تعرض الباحثة على الأطفال مجموعة من الأشياء من الطبيعة وتسالهم عن

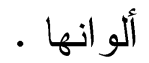
- تستمع الباحثة لإجابات الأطفال ثم تسالهم عن الألوان الأساسية و الألــــوان

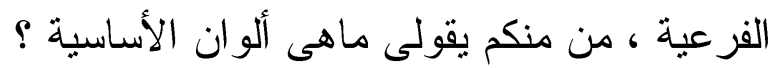

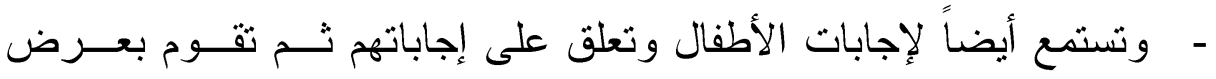

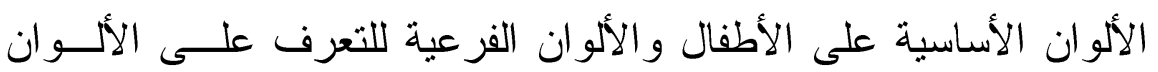

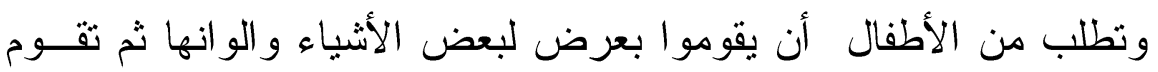

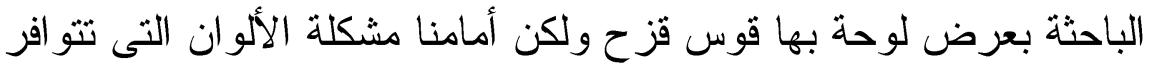


للدينا لتلوين اللوحة هى ( الأزرق - الأحمر - الأصــفر - الأبــبض -

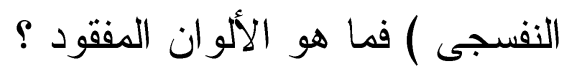

- - يجيب الأطفال اللون البرتقالى لتلوين و اللون الأخضر لتلوين قوس قز

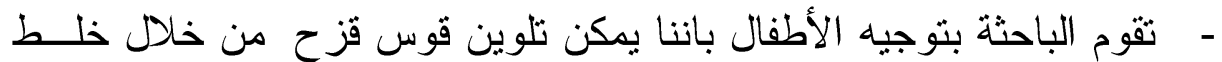

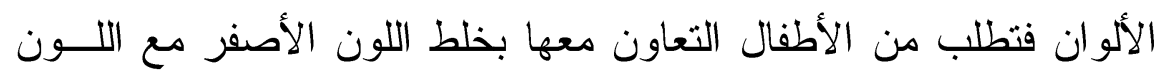
الأحمرفيكون الناتج اللون البرتقالى وخلط اللون الأزرق مع اللون الأصفر

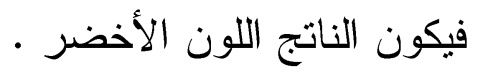
- تقدم الباحثة عرض لبعض الألو ان المختلطة و اللون الناتج ثم يقوم الأطفال

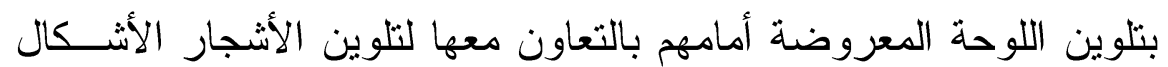

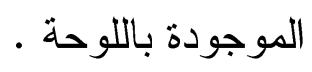

- وفى النهاية تشكر الباحثة الأطفال على حسن تعاونهم ومشـــاركتهم لهــا

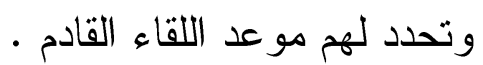

التقويميم :

أكمل : أكمل:

( ) ماهى المشكلة فى الموقف المعروض امامك r) تلاحظ الباحثة رغبة الأطفال فى حلى المشكلة المعروضة أمامـــة داخـلـل

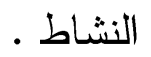

r) لون الطفل الصورة المعروضة عليك بالألوان المتاحة أمامك . ع) تطلب الباحثة من الطفل خلط اللون الازرق مع اللون الأصفر لإســتنتاج

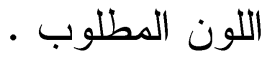

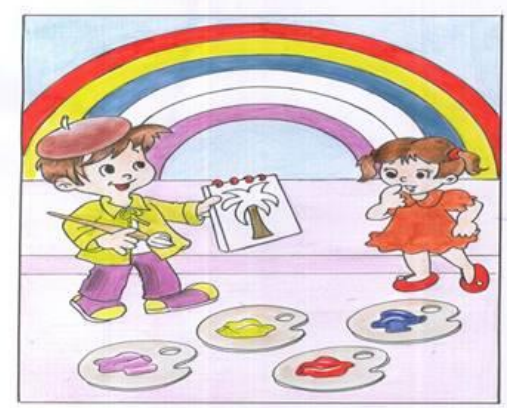


فاعلية برناهج تدريبى لتنهية بعض خصائص التفكير الإيجابى

لدى أطفال ها قبل المدربسة ذوى صعوبات التعلم لئم

\section{النشاط الثاني}

\section{الزهن : 0 د دقيقة}

نهوع النشاط : علمى

عنوان النشاط : ( إختلاط الأشياء )

أهداف النشاط :

( ) أن يحدد الطفل بعض الحلول للمشكلة الموجودة أمامة .

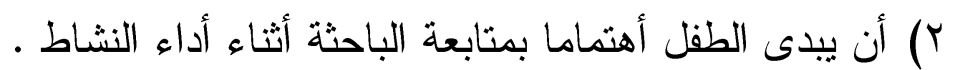
r) أن يستخدم الطفل المغناطيس لحل المشكلة المعروضة أمامة . ء) أن بستخرج الطفل الاشياء التى تتجذب للمغناطيس مــن بــين الأشــياء

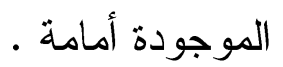

الأدوات المستخدهة :

( نشارة خشب - مسامير - أقلام - قصاصات ورق - أزرار - شمع -

قطع من المغناطيس - أشكال مصنو عة من الحديد ـ بر ادة حديد ) .

الفنيات المستفدهة : ( التعزيز ـ الأكتشاف الموجه ــ العصف الذهنى ) .

\section{سير النشاط :}

- ترحب الباحثة بالأطفال فى بداية النشاط وتطمئن عليهم وعلــى صـــهم

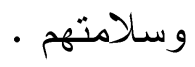

- تعرض الباحثة على الأطفال مجموعة من الأشياء المختلطة تحتوى علـى ولى

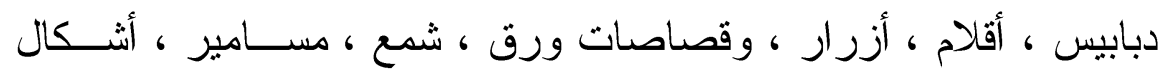
مصنو عة من الحديد . مصنم - - تطلب الباحثة من الأطفال أن يفكروا معها فى كيفية فصل الدبابيس وقطع

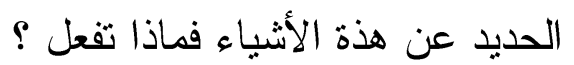


- تستمع الباحثة لأقتر احات الأطفال و أفكار هم لحل هذه المشكلة ، فــالبعض

يقترح عليها ان نقوم بفصل الدبابيس وقطع الحديد بأيدينا .

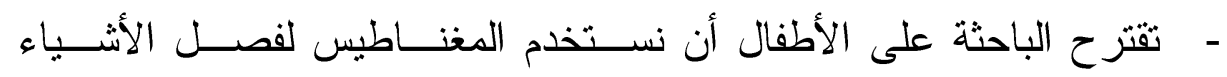

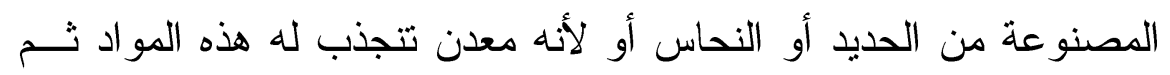
تجعل الأطفال أن يقوموا بالتجربة لاكتشاف ذلك بانفسهر .

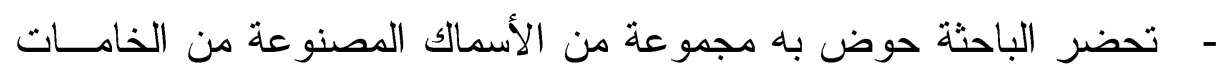

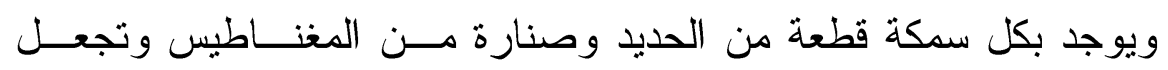
الأطفال يقومو ا بعملية الصيد وتقوم بتعزيز هم .

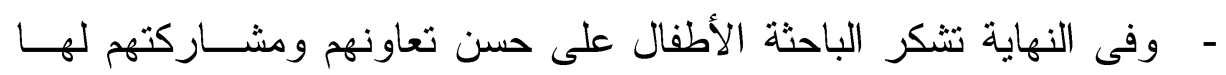

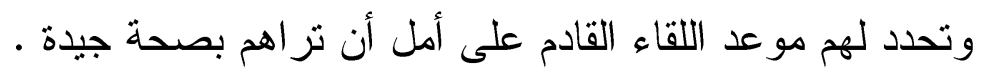

التقويم :

() تسأل الباحثة الطفل عن بعض الحلول للمشكلة الموجودة أمامة .

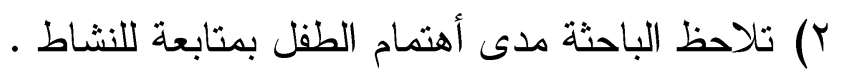

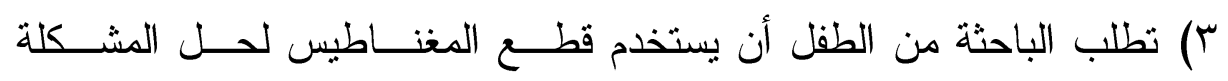

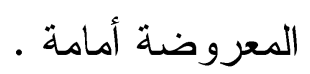
ع) تطلب الباحثة من الطفل إستخر اج الأشياء التى تتجذب إلى المغناطيس من بين الأشياء الموجودة أمامة .

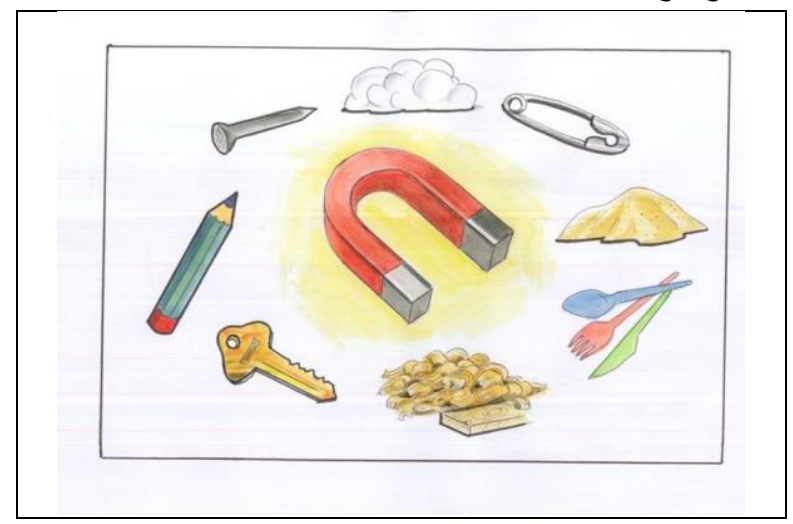


فاعلية برناهم تدريبى لتنهية بعض خصائص التفكير الإيجابى

لدى أطفال ها قبل المدربسة ذوى صعوبات التعلم لئم

\section{النشاط الثالث \\ الزهن : 0 د دقيقة \\ نوع النشاط : قصصى عنوان النشاط : الأرنب الغرور • \\ أهداف النشاط :}

() أن يعيد الطفل سرد أحداث القصة بثقة وفقا لترتيب أحداث البطاقات . r) أن يقارن الطفل بين سلوك الأرنب وسلوك السلحفاء طبقا لأحداث القصة . r) أن يدافع الطفل عن السلوك الإيجابى فى أحداث القصة . ع) أن يرثب الطفل أحداث بطاقات القصة . 0) الأدوات المستخدمة : قصة بطاقات . الأدوات المستخدهة : ( قصة بطاقات ) الفنيات المستفدهة : ( الإلقاء - التعزيز ـ الحوار و المناقشة )

: سير النشاط :

- ترحب الباحثة بالأطفال فى بداية النشاط وتطمئن على صحتهم وسلامتهم . - ثم تعرض لهم صورة أرنب وصورة سلحفاء وتسألهم ياترى مــين فــــهم البطى ومين السريع؟

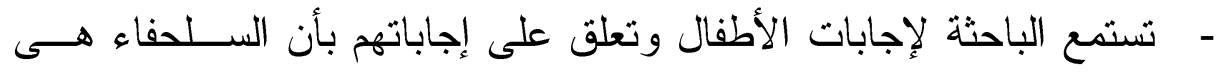
الأبطى من الأرنب ثم تعلق عليهم بعد ذلك بقولها ولكن بالرغم من ذلك بلإن

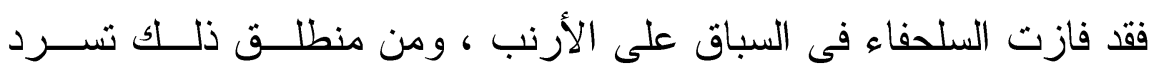
الباحثة أحداث القصة " بأن هناك أرنب أبيض يعيش مع إخواته الأرانـبـ

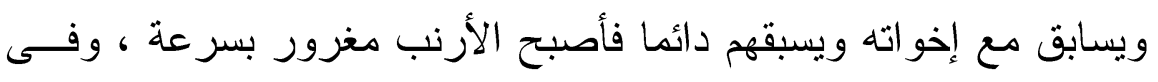
يوم من الايام ذهب إلى السلحفاء وهو يهز ا بها حيث قال لها : هيا نتسابق فربما فزتى عليا ، بدأ السباق بينهما حيث كانت السلحفاء بطيئة بطبيعتهــا 
ولكنها حافظت على سر عتها للفوز بالسباق وثقتها بنفسها ودافعيتها لأنجاز

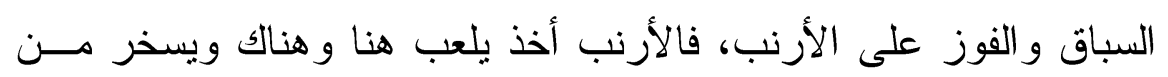
السلحفاء لتقته من الفوز فى السباق، حيث نظر الأرنب فجأة فر أى السلحفاء

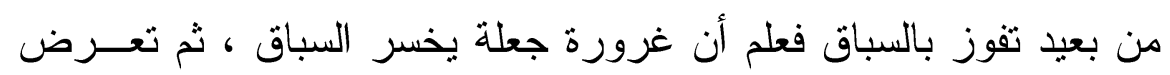

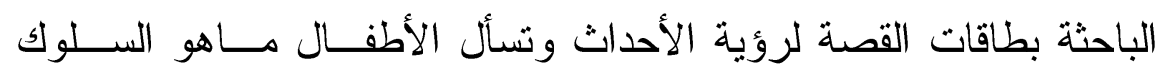
الإيجابى الذى حصلنا عليه من خلال سرد أحداث القصة . - وفى النهاية تشكر هم على حسن تعاونهم ومشاركتهم لها وتحدد لهم موعد أند اللقاء القادم على أمل أن تر اهم بصحة جيدة .

التقويم :

() تطلب الباحثة من الطفل إعادة سرد أحداث القصة بثقة وفقا لترتيب أحداث

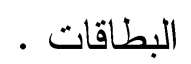

r) قارن بين سلوك الأرنب وسلوك السلحفاء طبقا لأحداث القصة . r) تلاحظ الباحثة دفاع الطفل عن السلوك الإيجابى فى أحداث القصة . ع) رثب أحداث بطاقات قصة الأرنب المغرور ·

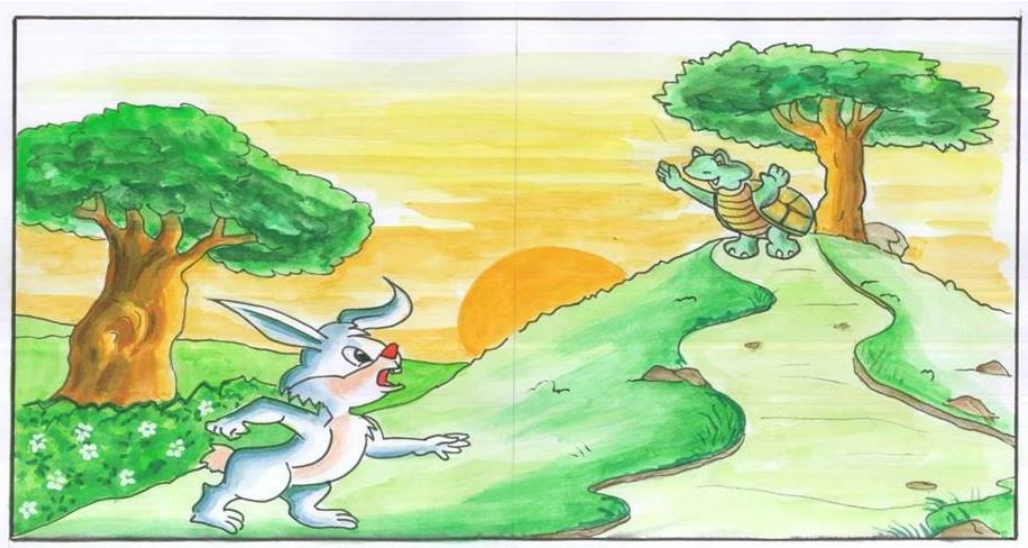


فاعلية برناهج تدريبى لتنهية بعض خصائص التفكير الإيجابى

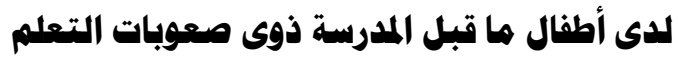

\section{رتب أحداث بطاقات القصة}

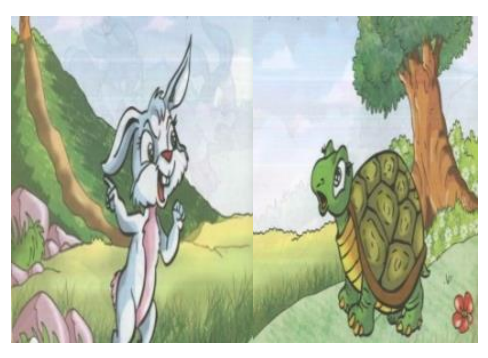

( )

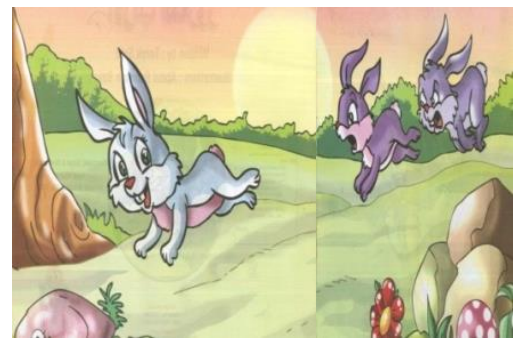

( )

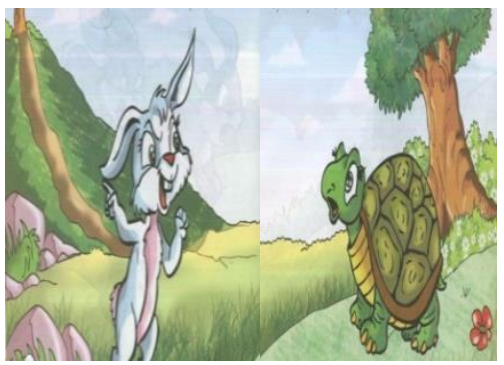

( )

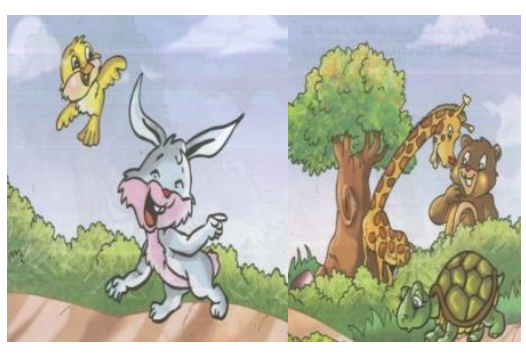

( ) 


\section{قائمة المراجع}

أولاً : المراجع العربية

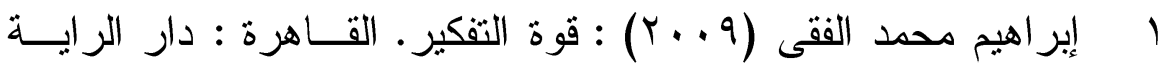

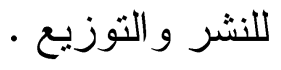

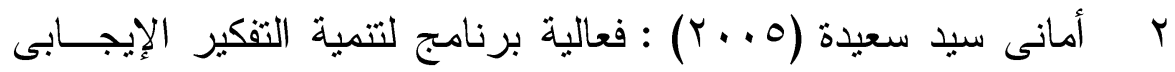

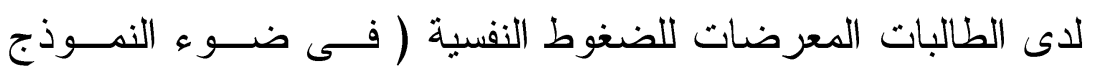
المعرفى) ، رسالة دكتور اة ، مجلة معهد الدراسات التربوية ، جامعة

القاهرة .

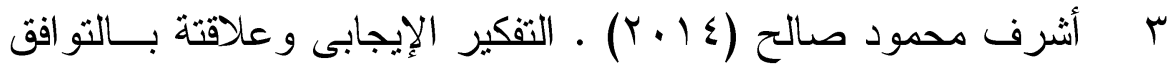

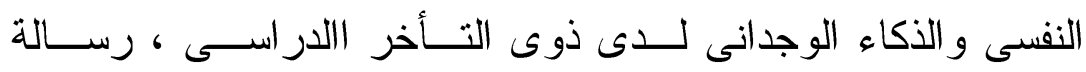
ماجستير ، كلية الأداب ، جامعة المنصورة .

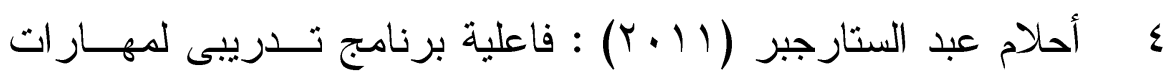
التفكير الإيجابى وأثرة فى تتمية بعض الخصائص النفسية و العقليـة

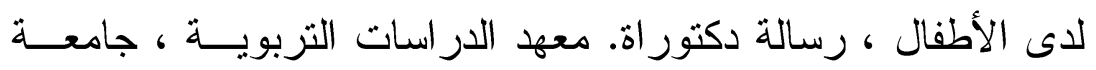
القاهرة .

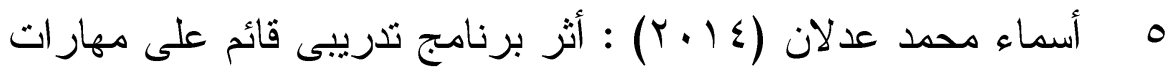
التفكير الإيجابى فى تتمية بعض سمات الشخصية وحـلـ المشـــلات لدى تلامبذ الحلقة الأعدادية ذوى صعوبات التعلم الإجتماعى ، رسالة دكتور اة ، معهد الدراسات التربوية ، جامعة القاهرة .

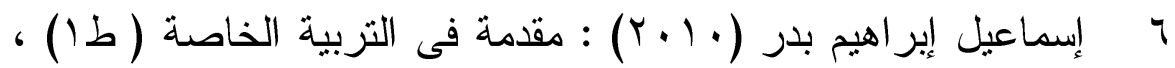

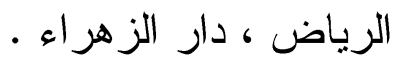

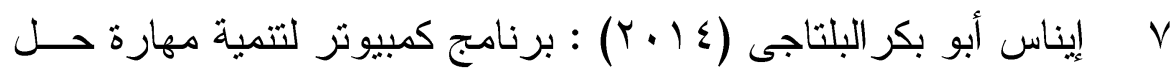

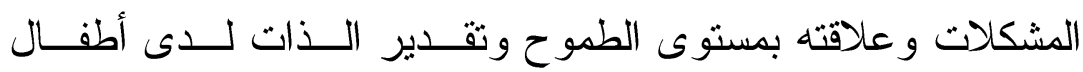


الروضة ذوى صعوبات التعلم ، رســالة دكتــور اة ، كليــة ريــاض

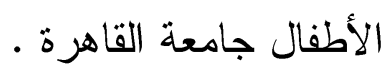

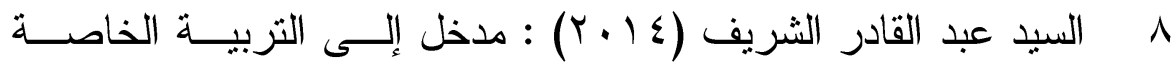

$$
\text { ( طا ) ، القاهرة ، دار الجوهرة . }
$$

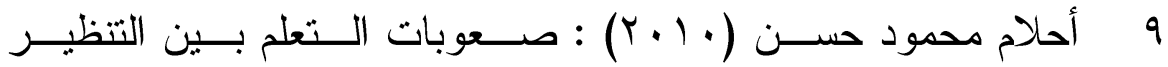
و التشخيص و العلاج ، الأزريطة ، مركز الإسكندرية للكتاب .

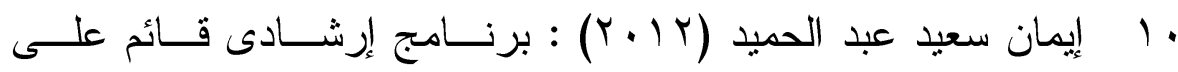
إستر اتيجيات التفكير الإيجابى لخفض بعض المشكلات السلوكية لدى

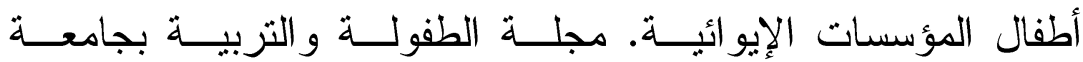

$$
\text { إسكندرية، r| (1) ، (1) }
$$

11

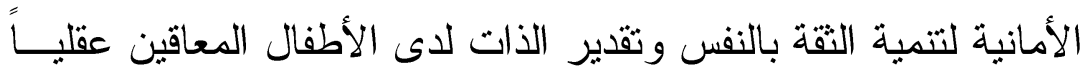

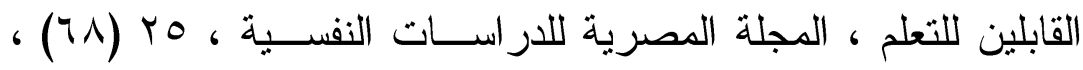
$.109-101$

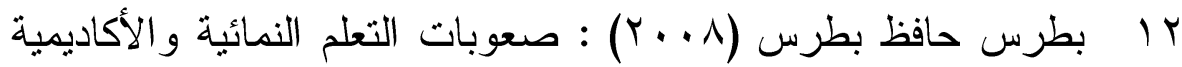

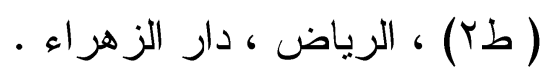

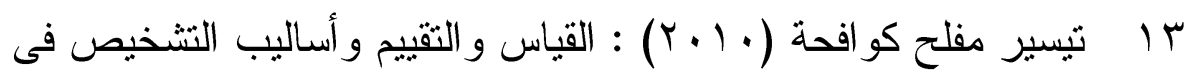
التربية الخاصة ( طب ) ، عمان ، دار المسيرة .

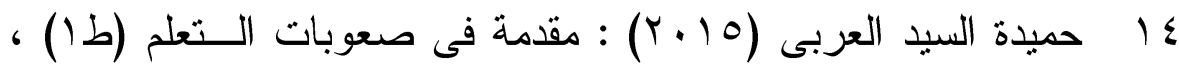
القاهرة ، دار الفكر العربى . 10 الأنشطة الحركية فى تتمية مهار ات التفكير الإيجــابى لــدى أطفــال الروضة ، مجلة التربية وثقافة الطفل ، المؤتمر الأول الدولى لكليــة الإسـ 
رياض الأطفال ، جامعة المنيا .

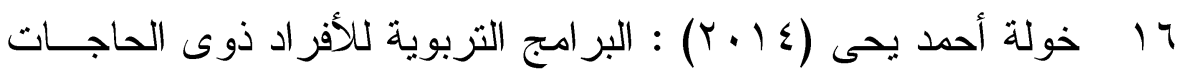
الخاصة (طه) ، عمان ، دار المسيرة . IV العلمية للأطفال (طץ) ، القاهرة ، دار الفكر العربى .

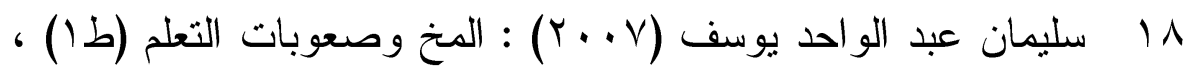

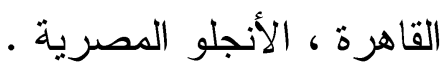
9 1 19 الاغتر اب النفسى وتحسين التحصبل الدراسى لاى الطلبة الموهــــين بالمرحلة المتوسطة بدولة الكويت ، رسالة دكتور اة ، معهد الدراسات

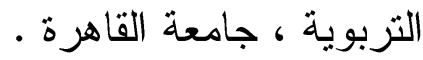

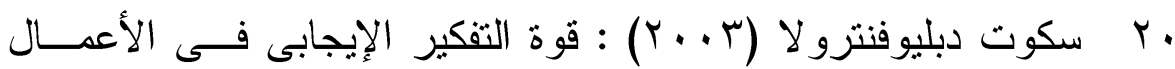
• (ط ا ) ، مكتبة العبيكان (1)

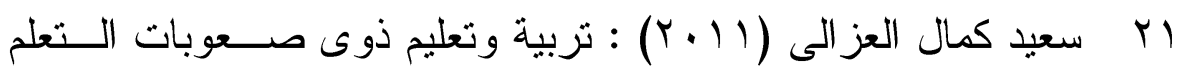

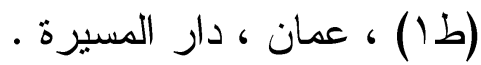

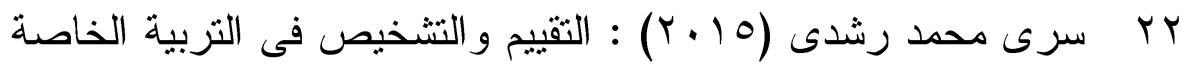

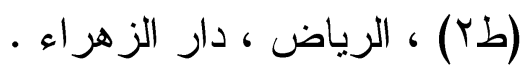

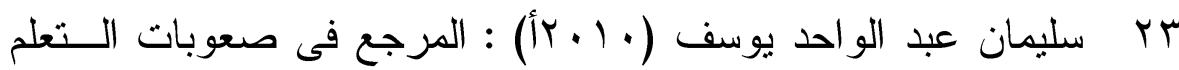

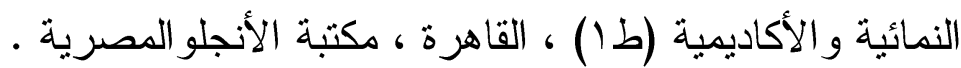

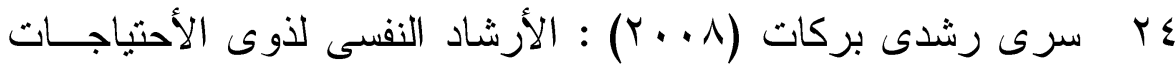
الخاصة (ط ا) ، الرياض ، دار الزهر هراء .

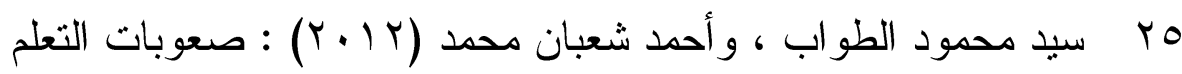
فى رياض الأطفال (ط ) ، الأزريطة ، مركز الأسكندرية للكتاب .

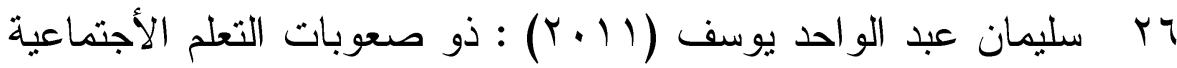




\section{فاعلية برنامج تدريبى لتنهية بعض خصائص التفكير الإيجابى}

لدى أطفال ها قبل المدرسة ذوى صعوبات التعلم

و الأنفعالية ( خصائصهم ، إكتشافه ، ر عايتهم ، مشكلاتهم ) (ط ا) ،

عمان ، دار المسيرة .

سليمان عبد الواحديوسف (· rV

لذوى الاحتياجات الخاصة ، الأسكندرية ، دار الجامعة الجديدة .

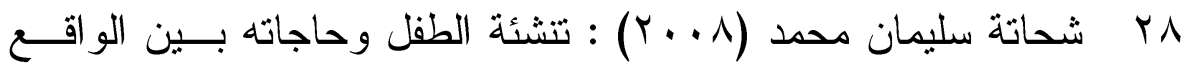
و المأمول ، مركز الأسكندرية ، الأزريطة .

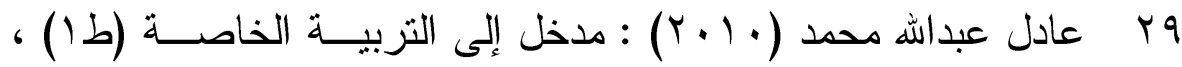

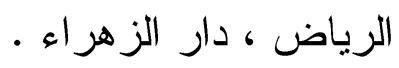

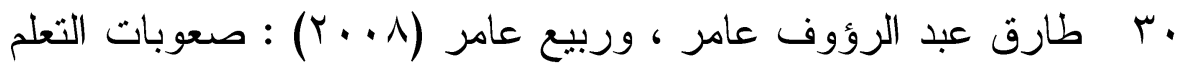
( مفهومة ، تشخيصة ، علاجها ) (ط ا) ، الجيزة .

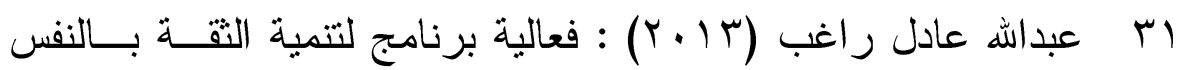
كمدخل لتحسين المسئولية الأجتماعبة لاى طلاب المرحلة الثانويــة ،

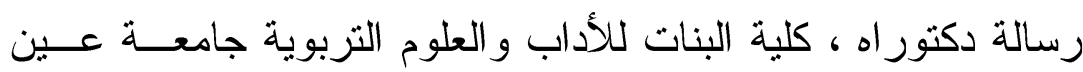

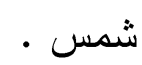

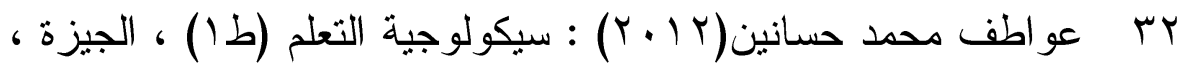

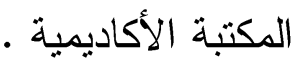

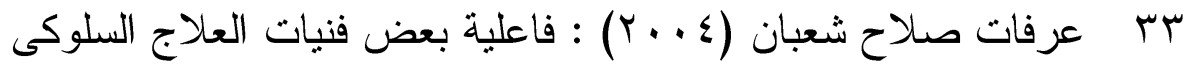
فى تعديل بعض المهار ات الأجتماعية للأطفال ذوى صعوبات التعلم . لمهيل رسالة دكتور اة ، معهد الدر اسات التربوية ، جامعة القاهرة .

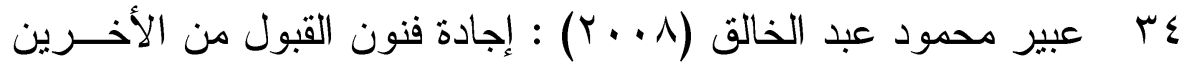
و علاقتها بالتفكير الإيجابى لدى الأطفال ، رســالة دكتـــور اة ، كليــة البنات ، جامعة عين شمس .

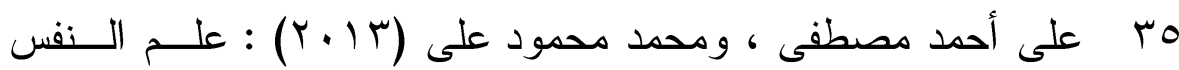




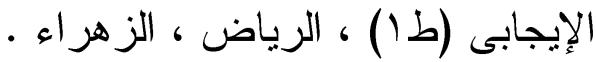

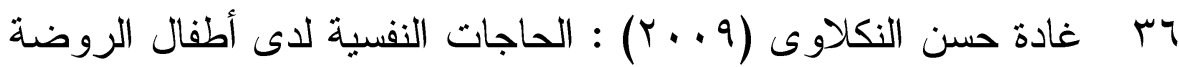
ذوى صعوبات التعلم ، رسالة ماجستير ، كلية ريــاض الأطفــال ،

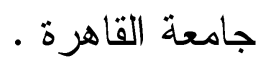

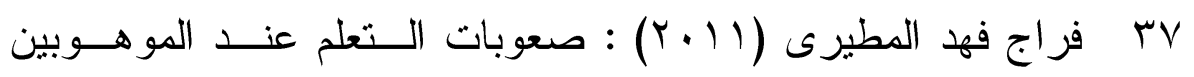

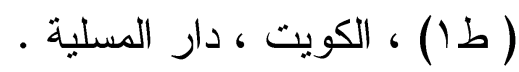

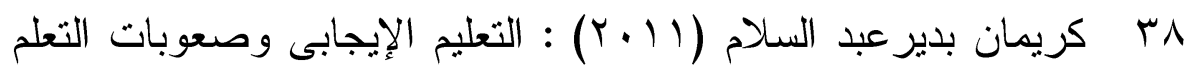

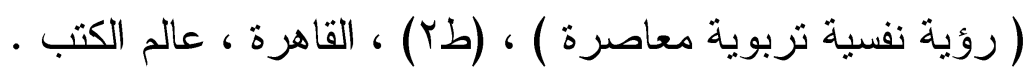

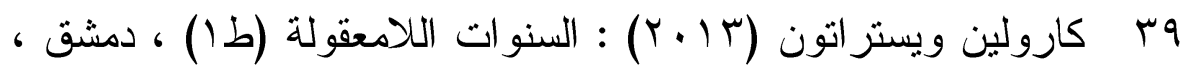
دار علاء.

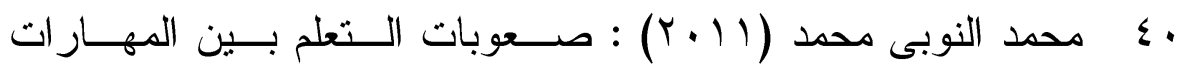

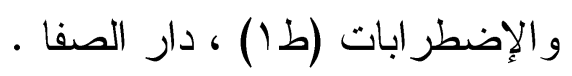

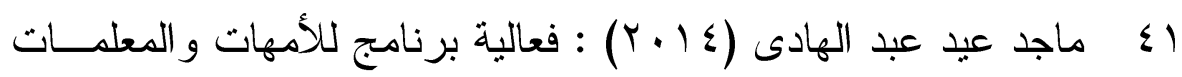

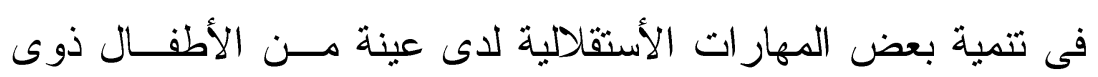
الأعاقة العقلية المتوسطة ، رسالة ماجستير ، كلية التربية جامعةعين شمس Y

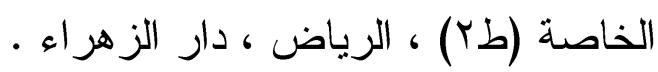

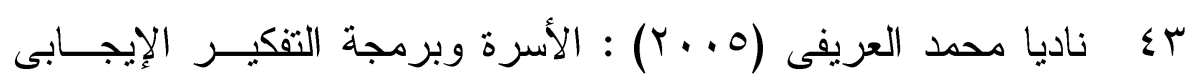

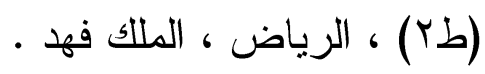

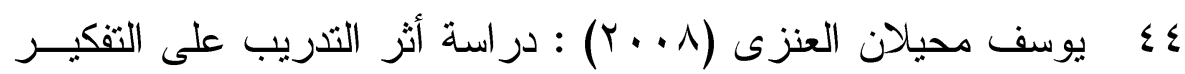

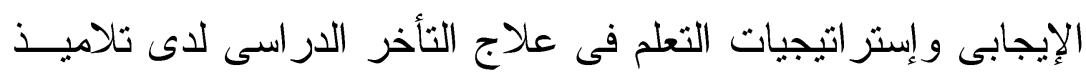

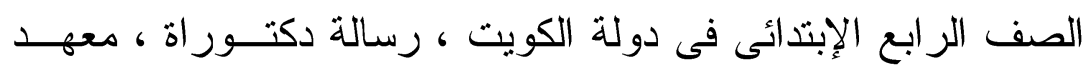

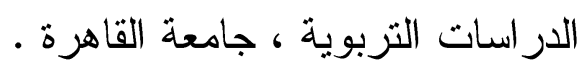




\section{ثانيا : المراجع الأجنبية}

45 Armstrong, J. (2002). Exploring the effects of individual dramatherapy with a child diagnosed with learning disabilities: a case study (Doctoral dissertation, Concordia University).

46 Bob Algozzine ,Robert Putnam,Robert H. Horner (2012).Support For Teaching students with learning Disabilities Academic skills and social behaviors within aRespanse-to- intervention model

47 Burnett, P. C. (1994). Self-talk in upper elementary school children: Its relationship with irrational beliefs, self-esteem, and depression. Journal of Rational-Emotive and Cognitive-Behavior Therapy, 12(3), 181-188.

48 Caprara, G. V., \& Steca, P. (2006). The contribution of self-regulatory efficacy beliefs in managing affect and family relationships to positive thinking and hedonic balance.

49 Journal of Social and Clinical Psychology, 25(6), 603.

50 Caprara, G. V., Steca, P., Gerbino, M., Paciello, M., \& Vecchio, G. M. (2006). Looking for adolescents' well-being: Self-efficacy beliefs as determinants of positive thinking and happiness. Epidemiologia e psichiatria sociale, 15(01), 30-43.

51 Collins,B(2004): The Effects Avoluntary Counseling Porgram For Students Experiencing Academic difficulty journal Of college Student Personnel Vol 23, No4,PP360-361.

52 Compbell,C,2005:Mativational Group Counseling For Law-Performing Students Journal for Specialists in group Work Vol15, No1,PP 43-50. 
53 Comer, U. B. (2009). Puppetry as an Instructional Practice for Children with Learning Disabilities: A Case Study. ProQuest LLC. 789 East Eisenhower Parkway, PO Box 1346, Ann Arbor, MI 48106.

54 Desoete, A., Ceulemans, A., De Weerdt, F., \& Pieters, S. (2012). Can we predict mathematical learning disabilities from symbolic and nonsymbolic comparison tasks in kindergarten? Findings from a longitudinal study. British Journal of Educational Psychology, 82(1), 64-81.

55 Froh, J. J., Bono, G., Fan, J., Emmons, R. A., Henderson, K., Harris, C., \& Wood, A. M. (2014). Nice thinking! An educational intervention that teaches children to think gratefully. School Psychology Review, 43(2), 132-152.

Fletcher, J. M. (2012). Classification and identification of learning disabilities. Learning about learning disabilities, 1-25.

56 Gallegos, J.(2008). Preventing childhood anxiety and depression: 54 -Testing the effectiveness of a school-based program in Mexico, The University of Texas at Austin.

57 Garry, M., Manning, C. G., Loftus, E. F., \& Sherman, S. J. (1996). Imagination inflation: Imagining a childhood event inflates confidence that it occurred. Psychonomic Bulletin \& Review, 3(2), 208-214.

58 Goldberg, C. (2005). The effects of elaborate help giving using 8th grade students with learning disabilities as peer tutors in computer classrooms. Arcadia University.

59 Hamid, A. E. (2015). Emotional and Behavioral Problems of Children with Learning Disabilities. Journal of Educational Policy and Entrepreneurial 
Research.

60 Hill, S. (2014). Narrative and person-centered art therapy for children with learning disabilities. Saint Mary's College of California.

61 Julie, K. N., \& Edward, C. C. (2002). The Positive Psychology of Negative Thinking. Journal of Clinical Psychology, 9, 993-1001.

62 Jenkins, Leslie R., Indiana U., US.(2014). Dissertation Abstracts Internationa: Humanities and Social Sciences, Vol 75(2-A).

63 Kamann, M. P., \& Wong, B. Y. (1993). Inducing adaptive coping self-statements in children with learning disabilities through self-instruction training. Journal of learning Disabilities, 26(9), 630-638.

64 Kimbrough Jr, R. B. (1997). The Mystique of the Successful College Administrator. College and University, 72(4), 9-13.

65 Lightsey Jr, O. R., \& Boyraz, G. (2011). Do positive thinking and meaning mediate the positive affectLife satisfaction relationship?. Canadian Journal of Behavioural Science/Revue canadienne des sciences du comportement, 43(3), 203.

66 McGuinness, C. (2013). Teaching thinking: Learning how to think. In Presented at the Psychological Society of Ireland and British Psychological Association's Public Lecture Series.

67 Montelpare, E. (2012). Children with an identified learning disability and their understanding of the social world (Doctoral dissertation, LAKEHEAD UNIVERSITY).

68 McCay, L. O., \& Keyes, D. W. (2001). Developing social competence in the inclusive primary classroom. Childhood Education, 78(2), 70-78.

69 Neck, C. P., \& Manz, C. C. (1992). Thought self- 
leadership: The influence of self- talk and mental imagery on performance. Journal of Organizational Behavior, 13(7), 681-699.

70 Shepherd, R. (2014). 6 Special educational needs and disabilities: Supporting the needs of children and young people through inclusive practice. Empowering the Children's and Young People's Workforce: Practice Based Knowledge, Skills and Understanding, 83.

71 Trujillo, Fran(2005) ." Positive Thinking for Children -- An Art and a Science." Independent School., Vol. 65 Issue 1, p116.

72 Stallard, P. (2003). Think good-feel good: A cognitive behaviour therapy workbook for children and young people. John Wiley \& Sons.

73 Telzrow, C. F., \& Bonar, A. M. (2002). Responding to students with nonverbal learning disabilities. Teaching Exceptional Children, 34(6), 8-13.

74 McMaster, M. (1995). Consciousness and Listening.

75 Talebizadeh, Sahar. (2009.College students with learning disability and perceived self-esteem as measured by the Behaviour Assessment System for Children (BASC-2)-College. Adler School of Professional Psychology.

76 Talebizadeh, Sahar. (2009.College students with learning disability and perceived self-esteem as measured by the Behaviour Assessment System for Children (BASC-2)-College. Adler School of Professional Psychology.

77 Wallace, G., \& McLoughlin, J. A. (1979). Learning disabilities: Concepts and characteristics. Merrill. 
